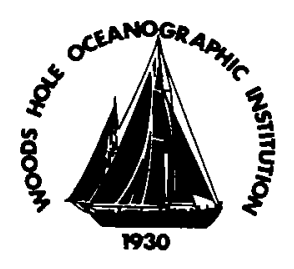

\title{
A Multidisciplinary Amazon Shelf SEDiment Study (AmasSeds): Physical Oceanography Moored Array Component
}

by

\author{
Carol A. Alessi' \\ Steven J. Lentz ${ }^{1}$ \\ Robert C. Beardsley ${ }^{1}$ \\ Belmiro M. Castro \\ W. Rockwell Geyer ${ }^{1}$
}

'Woods Hole Oceanographic Institution

Woods Hole, Massachusetts 02543

${ }^{2}$ Instituto Oceanografico Universidade Sao Paulo

Sao Paulo, Brasil

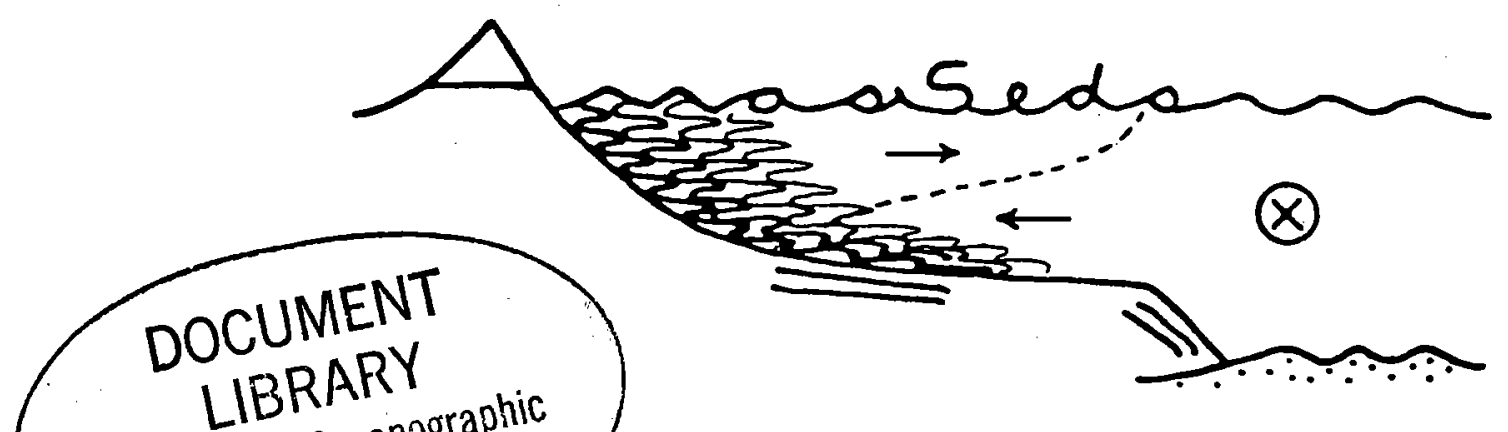

Woods Hoie Oceanographic
Inscitution

\section{Technical Report}

Funding was provided by the National Science Foundation through Grant Nos.

OCE 88-12917 and OCE 91-15712.

Approved for public release; distribution unlimited. 


\title{
A Multidisciplinary Amazon Shelf SEDiment Study (AmasSeds): Physical Oceanography Moored Array Component
}

\author{
by \\ Carol A. Alessi ${ }^{1}$ \\ Steven J. Lentz' \\ Robert C. Beardsley' \\ Belmiro M. Castro² \\ W. Rockwell Geyer ${ }^{1}$ \\ ${ }^{1}$ Woods Hole Oceanographic Institution \\ Woods Hole, Massachusetts 02543 \\ ${ }^{2}$ Instituto Oceanografico Universidade Sao Paulo \\ Sao Paulo, Brasil
}

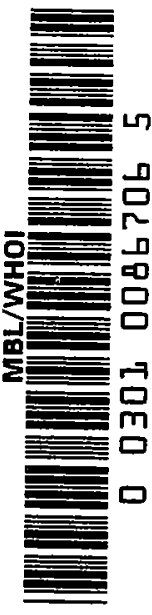

September 1992

Technical Report

Funding was provided by the National Science Foundation through Grant Nos.

OCE 88-12917 and OCE 91-15712.

Reproduction in whole or in part is permitted for any purpose of the

United States Government. This report should be cited as:

Woods Hole Oceanog. Inst. Tech. Rept., WHOI-92-36.

Approved for publication; distribution unlimised.

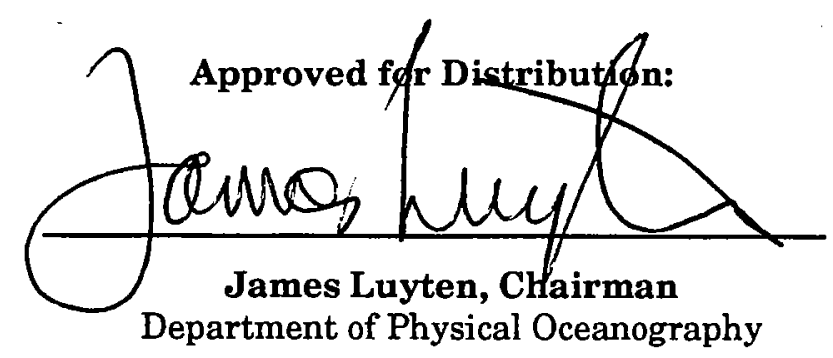




\section{Table of Contents}

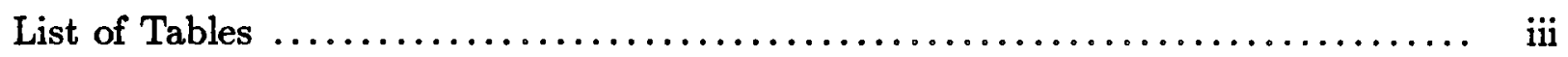

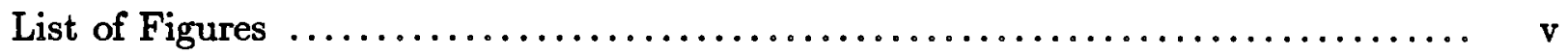

List of Appendix Tables and Figures $\ldots \ldots \ldots \ldots \ldots \ldots \ldots \ldots \ldots \ldots \ldots \ldots \ldots \ldots$ vii

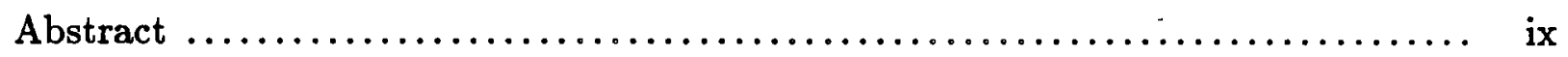

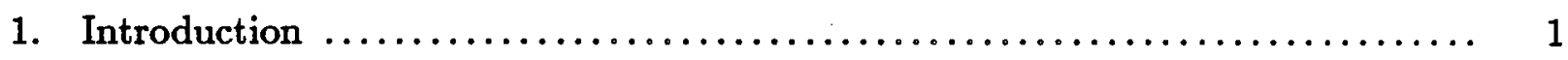

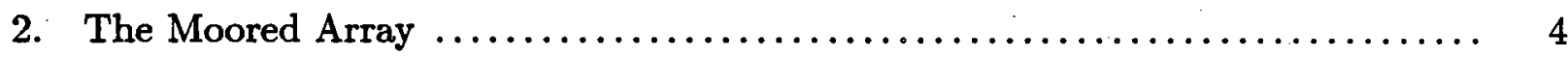

2.1 Moored Array Location and Timing $\ldots \ldots \ldots \ldots \ldots \ldots \ldots \ldots \ldots \ldots \ldots, 4$

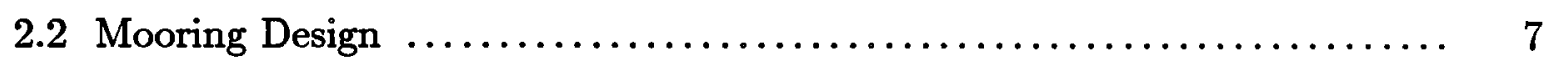

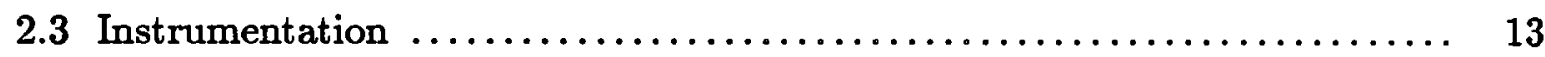

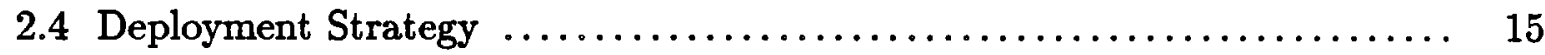

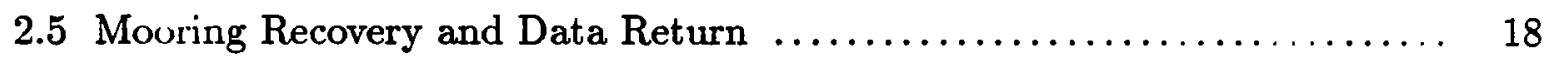

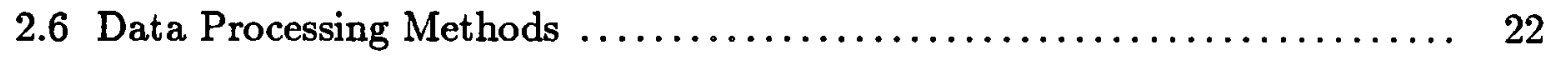

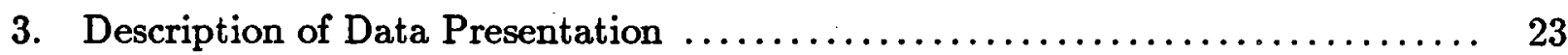

4. Acknowledgments ......................................... 28

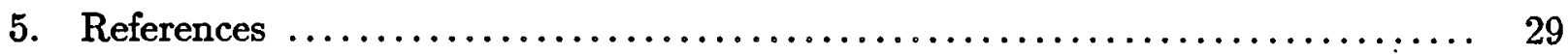

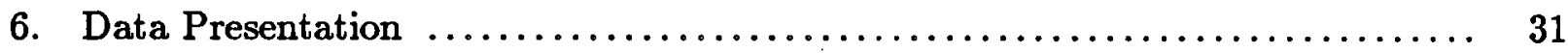

Appendix: Evaluation of the AmasSeds M3 Current Meter Data ............. 79 


\section{List of Tables}

1. Sediment and Water Discharge for the 10 Rivers with Greatest Sediment Discharge ... 2

2. Principal Participants and Scientific Components $\ldots \ldots \ldots \ldots \ldots \ldots \ldots \ldots \ldots \ldots \ldots \ldots$

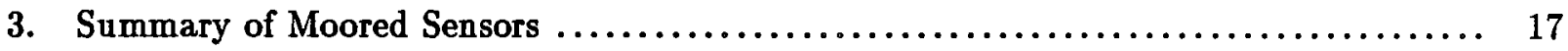

4. Statistics of Hourly Averaged Data - Entire Time Period, For: $\ldots \ldots \ldots \ldots \ldots \ldots \ldots .24$

Cross-Isobath and Along-Isobath Velocity $\ldots \ldots \ldots \ldots \ldots \ldots \ldots \ldots \ldots \ldots \ldots \ldots \ldots \ldots, 24$

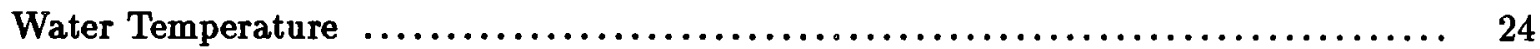

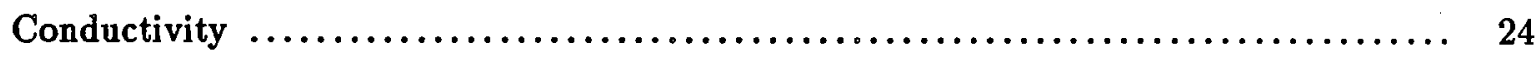

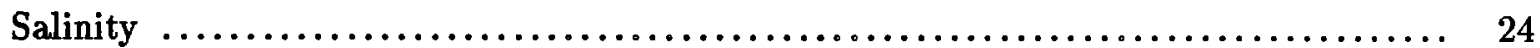

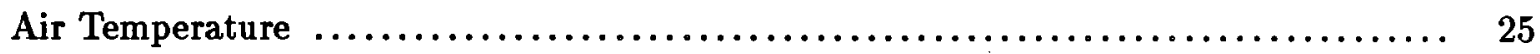

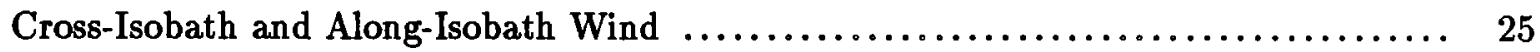

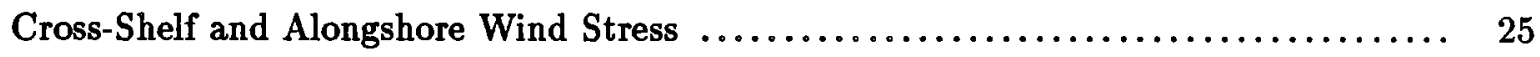

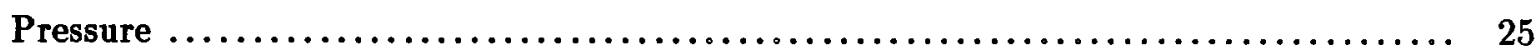

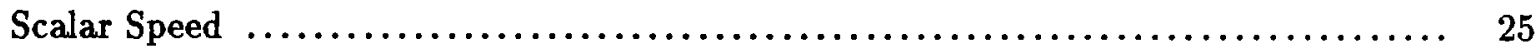

5. Statistics of Hourly Averaged Data - Common Time Period, For: ............. 26

Cross-Isobath and Along-Isobath Velocity $\ldots \ldots \ldots \ldots \ldots \ldots \ldots \ldots \ldots \ldots \ldots \ldots \ldots \ldots$

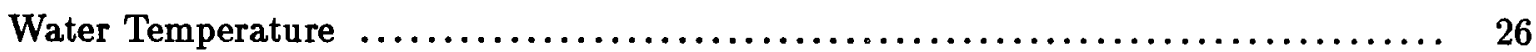

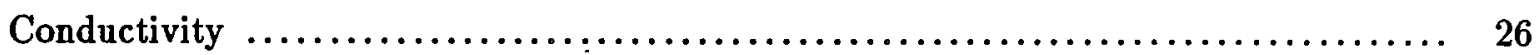

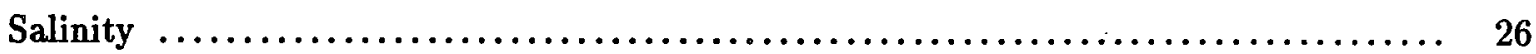

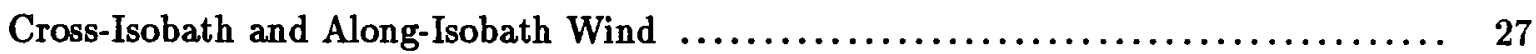

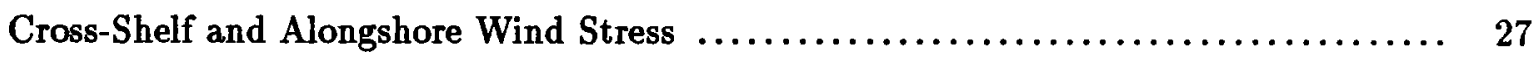

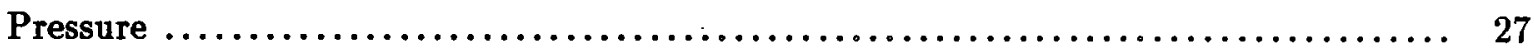

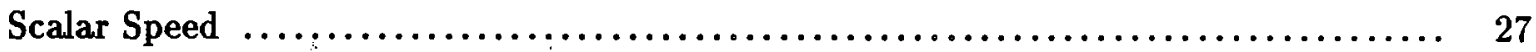




\section{List of Figures}

Figure 1. Bathymetric chart of the Amazon shelf and slope showing the . . 5 locations of the three AmasSeds mooring sites. Also shown are the locations of the three-element STACS moored array.

Figure 2. Cross-section of the shelf with the bottom profile and instrument $\ldots 6$ locations.

Figure 3. Timeline of the primary physical processes affecting the Amazon $\ldots 8$ shelf.

Figure 4. Schematics of the AmasSeds moorings. $\ldots 9$

Figure 5. Relative positions for the surface and subsurface moorings at M1 $\ldots 12$ and M2.

Figure 6. Schematic of the dual-rotor VACM. $\quad \ldots 14$

Figure 7. InterOcean S4 and the IOUSP SD2000 current meter. $\ldots 16$

Figure 8. Data return from the AmasSeds moored array. $\ldots 19$

Figure 9. Time series of the hourly-averaged M2 and ECMWF wind records $\ldots 21$ for 23 days.

Figure 10. Time series of the hourly-averaged air temperature, M2 and . .34 ECMWF wind records for the entire time period.

Figures 11-16. Composite (stacked) plots of the PL64 low-pass filtered currents. . . .36

Figures 17-20. Composite (stacked) plots of the hourly averaged current com- . . 48 ponents.

Figures 21-22. Composite (overlay) plots of the PL64 low-pass filtered water tem- $\ldots 56$ perature and salinity time series records.

Figures 23-29. Composite (stacked) plots of the hourly averaged individual water $\ldots$ 60 temperature, salinity and conductivity time series records.

Figure 30. Hourly-averaged and PL64 low-pass filtered time series of the two $\ldots 74$ speed records from the dual rotor VACM.

Figure 31. Time series of the hourly-averaged barometric pressure record. $\quad \ldots 76$ 


\section{List of Appendix Tables}

A1. Unidirectional Velocity Profiles Used as Input into Mooring Dynamics Model ....... 82

A2. Variable Parameters for the Mooring Dynamics Model $\ldots \ldots \ldots \ldots \ldots \ldots \ldots \ldots \ldots . . .62$

\section{List of Appendix Figures}

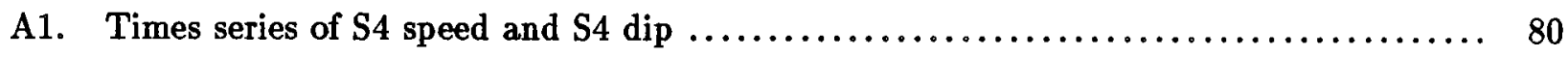

A2. Observed and predicted S4 dip plotted as a function of $\mathrm{S} 4$ speed $\ldots \ldots \ldots \ldots \ldots \ldots$

A3. Time series of S4 corrected speed and the difference between the top SD2000 speed

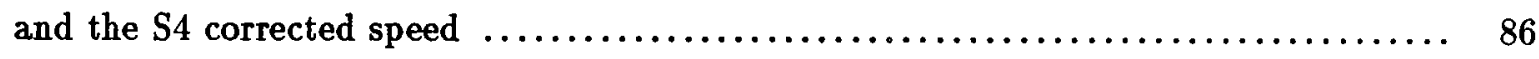


viii 


\begin{abstract}
A Multidisciplinary Amazon Shelf SEDiment Study (AmasSeds) is a cooperative research program by geological, chemical, physical, and biological oceanographers from Brazil and the United States to study sedimentary processes occurring over the continental shelf near the mouth of the Amazon River. The physical oceanography component of AmasSeds included a moored array deployed on the continental shelf approximately $300 \mathrm{~km}$ northwest of the Amazon River mouth near $3.5^{\circ} \mathrm{N}$. The moored array consisted of a crossshelf transect of three mooring sites located on the $18-\mathrm{m}, 65-\mathrm{m}$, and $103-\mathrm{m}$ isobaths. The moored array was deployed for approximately 4 months, from early February, 1990 to mid-June, 1990, obtaining time series measurements of current, temperature, conductivity, and wind. This report describes the physical oceanography moored array component and provides a statistical and graphical summary of the moored observations.
\end{abstract}




\section{Introduction}

A Multidisciplinary Amazon Shelf SEDiment Study (AmasSeds) is a cooperar, tive research program being conducted by geological, chemical, physical, and biological oceanographers from Brazil and the United States. The AmasSeds program was designed to study the continental shelf near the mouth of the Amazon River with emphasis on the major sedimentary processes. The Amazon River annually discharges into the Atlantic Ocean over six trillion cubic meters of fresh water, a billion tons of sediment, and nearly a billion tons of dissolved material (Table 1). On a global basis, these totals represent $18 \%$ of the fresh water (Oltman, 1968), 10\% of the fluvial sediment (Meade et al., 1985), and $8 \%$ of the dissolved solids (Gibbs, 1972) entering the oceans from rivers. The AmasSeds program was designed to investigate the processes influencing the dispersal and ultimate fate of these constituents as they flow out onto the North Brazil continental shelf.

There are five research components comprising AmasSeds: (1) Physical Oceanography, (2) Sediment Transport, (3) Turbidity Effects on Geochemistry, (4) Diagenetic/Authigenetic Processes, and (5) Sedimentology and Stratigraphy. The principal investigators and research topics of each group are listed in Table 2. A detailed description of the AmasSeds research program, its development, and scientific objectives were presented in Eos by the AmasSeds Research Group (1990). A brief description of past research on the Amazon shelf and preliminary results from each of the five research components were presented at a special session at the 1990 AGU Fall Meeting and in the April, 1991 issue of Oceanography. The physical oceanographic results (including some results from the moored array measurements) were presented in Oceanography by Geyer et al. (1991).

The Physical Oceanography component of AmasSeds was designed: to characterize the temporal and spatial variability of the Amazon River plume as it flows northwestward over the Amazon shelf; to determine the processes influencing the plume dynamics, including mixing between the plume and the surrounding ocean water; and to investigate physical processes influencing the sediment distribution over the shelf, including bottom stress. To address these objectives, the physical oceanography field work included:

- Long-term moored measurements of wind, current, temperature, and conductivity to determine tidal and low-frequency variability in the shelf flow field, stratification, surface wind stress, and bottom stress;

- A series of four regional hydrographic (CTD) and acoustic Doppler current profiler (ADCP) surveys to measure the spatial distributions of temperature, salinity, density, turbidity and currents over the Amazon shelf during the four stages (falling, low, rising, and high) of the river discharge cycle; 
Table 1: Discharge of sediment and water for the ten rivers with greatest sediment discharge

(from Milliman and Meade, 1983; Meade et al., 1985)

\begin{tabular}{|lcc|}
\hline River & $\begin{array}{c}\text { Sediment } \\
\text { Discharge } \\
\left(\mathbf{1 0}^{6} \text { tons/yr }\right)\end{array}$ & $\begin{array}{c}\text { Water } \\
\text { Discharge } \\
\left(\mathrm{km}^{3} / \mathrm{yr}\right)\end{array}$ \\
\hline Ganges/Brahmaputra & 1670 & 971 \\
Amazon & 1200 & 6300 \\
Huangho (Yellow) & 1080 & 49 \\
Changjiang (Yangtze) & 478 & 900 \\
Irrawaddy & 285 & 428 \\
Magdalena & 220 & 237 \\
Mississippi & 210 & 580 \\
Orinoco & 210 & 1100 \\
Hungho (Red) & 160 & 123 \\
Hekong & 160 & 470 \\
\hline
\end{tabular}


Table 2: List of participants and research topics in the five scientific components of AmasSeds

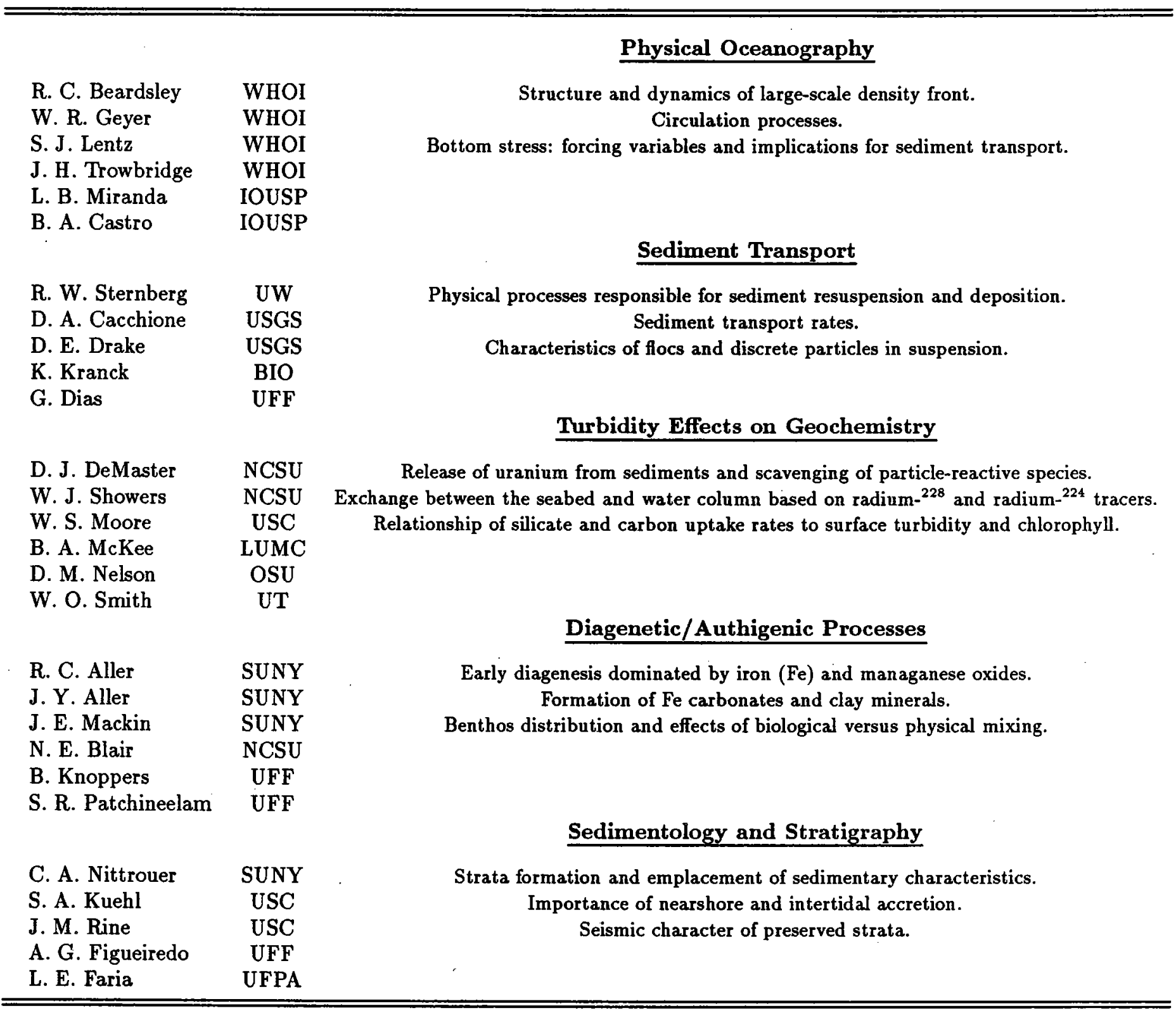

Notes:

C. A. Nittrouer and D. J. DeMaster were responsible for overall project administration.

\footnotetext{
BIO: Bedford Institute of Oceanography

IOUSP: Institute of Oceanography, University of Sao Paolo, Brazil

LUMC: Louisiana University Marine Consortium

NCSU: North Carolina State University

OSU: Oregon State University

SUNY: State University of New York, Stony Brook

UFF: Universidade Federal Fluminense
}

UFPA: Universidade Federal do Pará

USC: University of South Carolina

USGS: U.S. Geological Survey, Menlo Park, CA

UT: University of Tennessee

UW: University of Washington

WHOI: Woods Hole Oceanographic Institution 
- Short-term, high-resolution measurements of the small-scale circulation, and mixing processes in the frontal zone between the Amazon River plume and the more saline ocean water;

- Lagrangian observations of near-surface circulation using satellite-tracked drifters;

- Synoptic observations of the near-surface suspended sediment distribution through satellite imagery.

Technical reports presenting the edited hydrographic data have been published by Limeburner and Beardsley (1989, 1991a,b) and Limeburner et al. (1992). This report focuses on the long-term moored array component. The moored array component is described in Section 2, which includes a description of the site and the moored array, a summary of the instrumentation, the data return, and the data processing procedures. A description of the data presentation, and statistical summaries of the moored data are given in Section 3. Time-series plots of unfiltered (hourly averages) and low-pass filtered data for each instrument are presented in Section 6. Time series plots of the following variables are presented: wind, air temperature, barometric pressure, current, water temperature, conductivity, and salinity (derived from temperature and conductivity measurements).

\section{The Moored Array}

\subsection{Moored Array Location and Timing}

Primary objectives of the physical oceanography component of AmasSeds were to characterize the temporal variability of current, temperature, and salinity over the North Brazil shelf and to relate that variability to likely forcing such as the Amazon River discharge, the North Brazil Current (NBC), and the local wind stress. To address these objectives, a three-element moored array of wind, current, temperature, and conductivity sensors was deployed on an open-shelf transect perpendicular to the shelf topography. The location of the moored array is shown in Figure 1 along with the SubTropical Atlantic Climate Study (STACS) moored array discussed in the next paragraph.

The AmasSeds moored array was deployed about $300 \mathrm{~km}$ northwest of the river mouth, across the region of highest sediment accumulation defined by Kuehl et al. (1986). The shelf is about $230-\mathrm{km}$ wide in the vicinity of the moored array (Figure 2). From the coast to the $20-\mathrm{m}$ isobath ( $125 \mathrm{~km}$ offshore), the bottom is nearly flat (slope $\approx 10^{-4}$ ). The bottom then drops more steeply (slope $\approx 10^{-3}$ ) between the $20-\mathrm{m}$ isobath and the shelfbreak. Mooring sites were located over the flat inner shelf on the 18-m isobath (designated M1), over the steeper portion of the mid-shelf near the $65-\mathrm{m}$ isobath (designated 


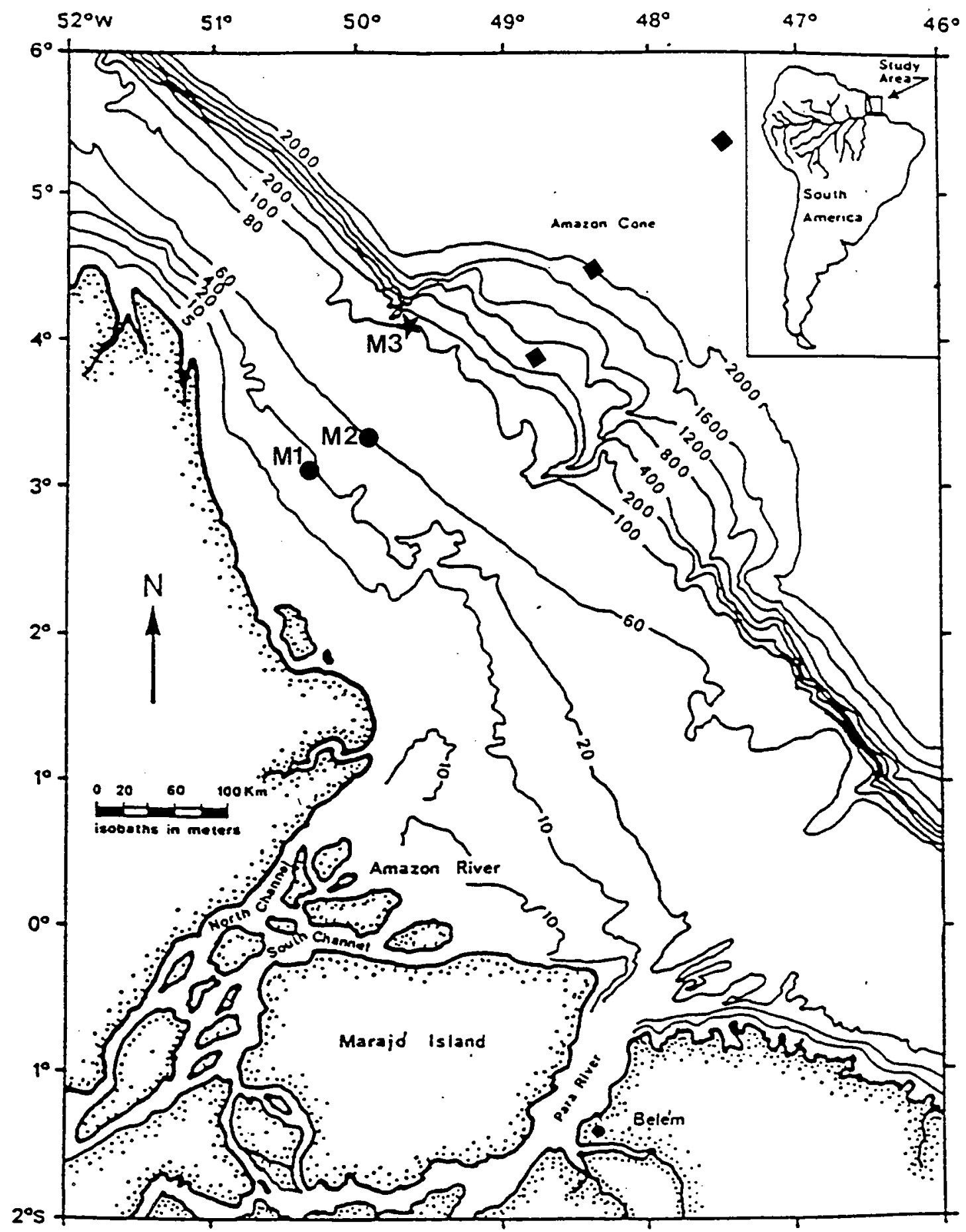

Figure 1: Bathymetric chart of the Amazon shelf and slope showing the locations of the two AmasSeds mooring sites deployed by WHOI(ø), the joint WHOI/IOUSP mooring site $(*)$, and the three-element STACS moored array $(\boldsymbol{\theta})$. 


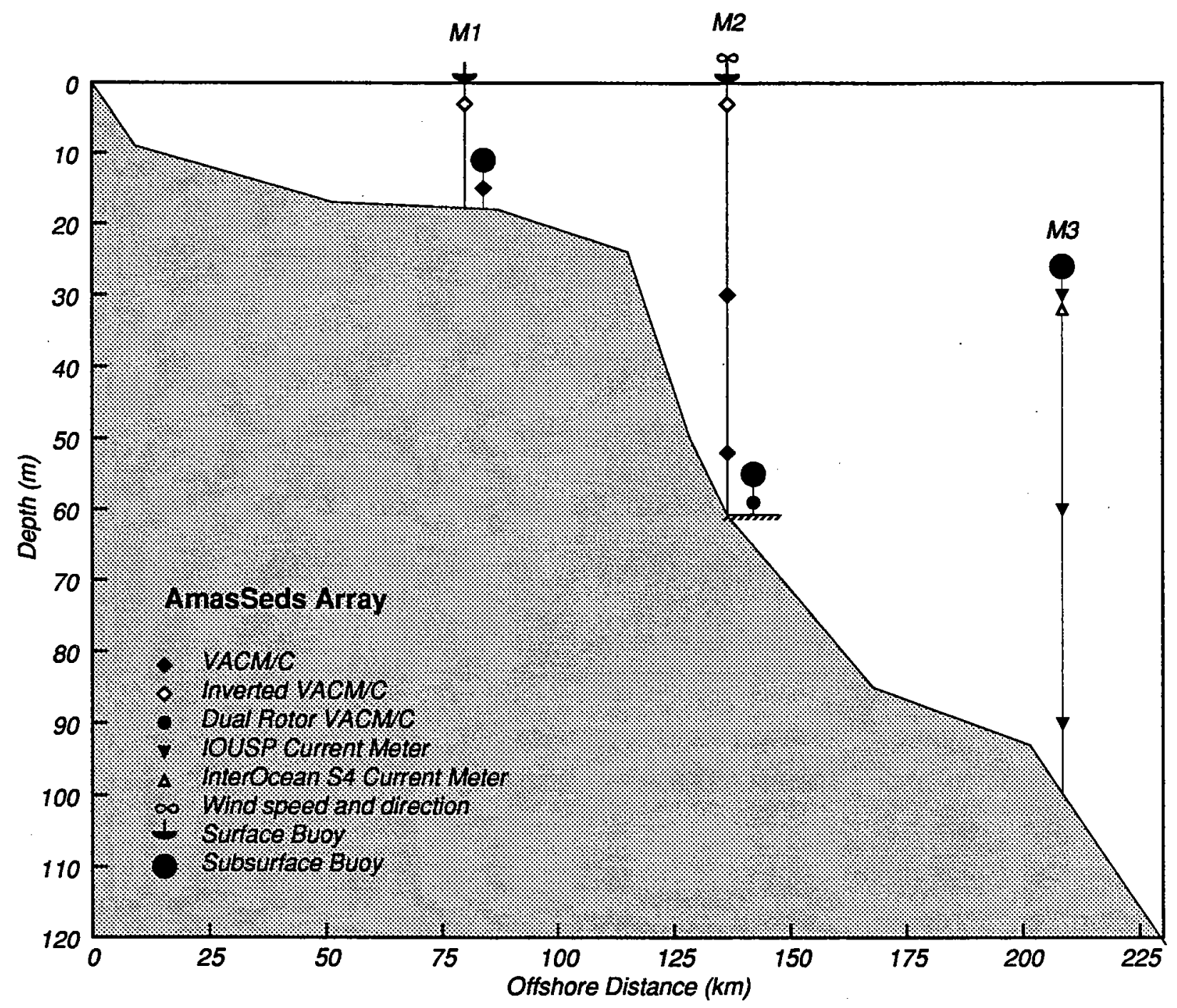

Figure 2: Cross-section of the shelf at the open-shelf transect showing the bottom profile and instument locations for the AmasSeds moored array. The wavewrider deployed at M1 is not shown, and was never recovered. 
M2), and near the shelf break on the 103-m isobath (designated M3). The M1 and M2 moorings bracketed the region of high net sediment accumulation. At the moored array, hydrographic surveys indicated that the Amazon plume was typically 5-10 $\mathrm{m}$ thick and usually extended offshore from the coast beyond the M2 mooring. The M3 mooring was deployed with joint Brazil/US support to provide a link between the AmasSeds array and the STACS moored array which was deployed across the NBC (Figure 1) to study its velocity structure and transport variability (Johns et al., 1990).

The AmasSeds moored array was deployed for a period of four months, from early February, 1990 to mid-June, 1990. The timing was chosen to span the period of rising Amazon discharge (Figure 3) when maximum sediment discharge was assumed to occur. During this period, transport of the NBC was near its minimum and the wind stress was decreasing from its seasonal maximum in February (Figure 3). The STACS moored array was deployed for a period of seven months, from February 1, 1990 to September 25, 1990. The period of AmasSeds and STACS moored array data overlap extended from February 9 , 1990 to June 18, 1990.

\subsection{Mooring Design}

A total of six moorings were designed and fabricated at WHOI for the AmasSeds moored array component, three surface and three subsurface moorings. Strong tidal and subtidal currents, shallow water, large tidal depth variations, unstable bottom characteristics, intensive coastal fishing activity, and scarce background data resulted in a challenging mooring design problem. Surface currents were expected to reach a maximum of nearly 5 knots $(2.5 \mathrm{~m} / \mathrm{s})$. The final designs shown in Figure 4 used a pair of surface and subsurface moorings at M1 and M2 and a subsurface mooring at M3. All the moorings supported current meters spanning the water column. In addition, the M2 mooring also supported a wind recorder, and a waverider was deployed at M1. The relative positions of the surface and subsurface moorings at mooring sites M1 and M2 as well as the waverider deployed at M1 are shown in Figure 5. Also shown in Figure 5 is the position of the instrumented bottom tripod, GEOPROBE. The tripod was deployed by USGS to study sediment transport and the physical processes (using current measurements at four levels) influencing sediment dynamics (Oceanography, 4, 21-26).

The M1 and M2 subsurface moorings were short enough that only chain was used between mooring components. A ground chain to a secondary anchor with a small surface marker buoy was used as a two-stage recovery method. If the surface marker buoy had disappeared, the chain on the bottom could have been used as a target for a grappling trawl recovery. The M3 mooring was deployed with an acoustic release at the shelf break where there was relatively little fishing activity. 

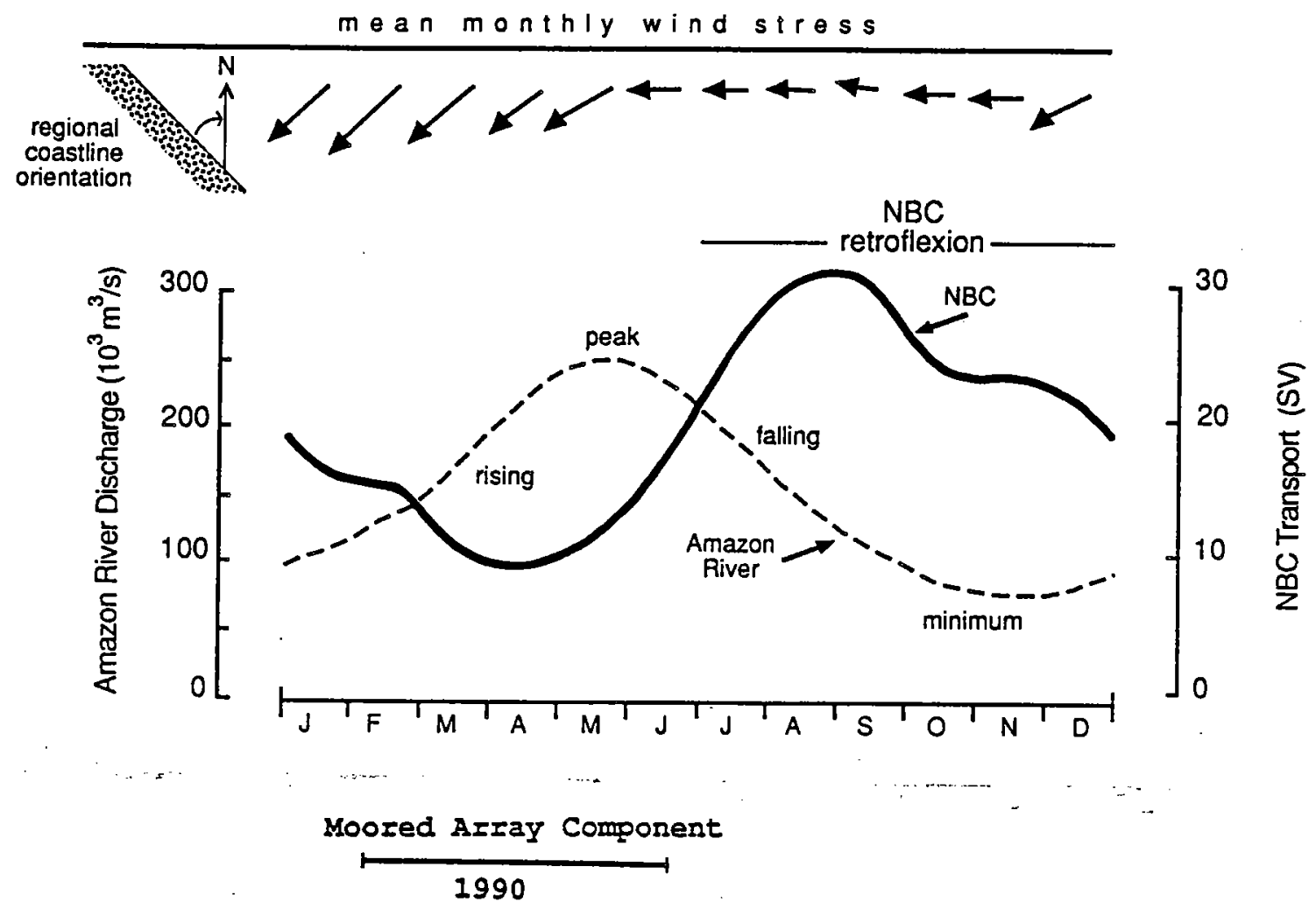

Figure 3: Timeline showing the moored array deployment period in the context of the seasonal cycle. The peak wind stress occurring in February is about $1.1 \mathrm{dyn} \mathrm{cm}^{-2}$ (Picaut et al., 1985). The flow of the North Brazil Current (NBC) (Philander and Pacanowski, 1986) is given in Sverdrups $\left(\times 10^{6} \mathrm{~m}^{3} \mathrm{~s}^{-1}\right.$ ). The current flows northwestward along the coast, but retroflects eastward during part of the year. (Modified from Nittrouer et al., 1991.) 


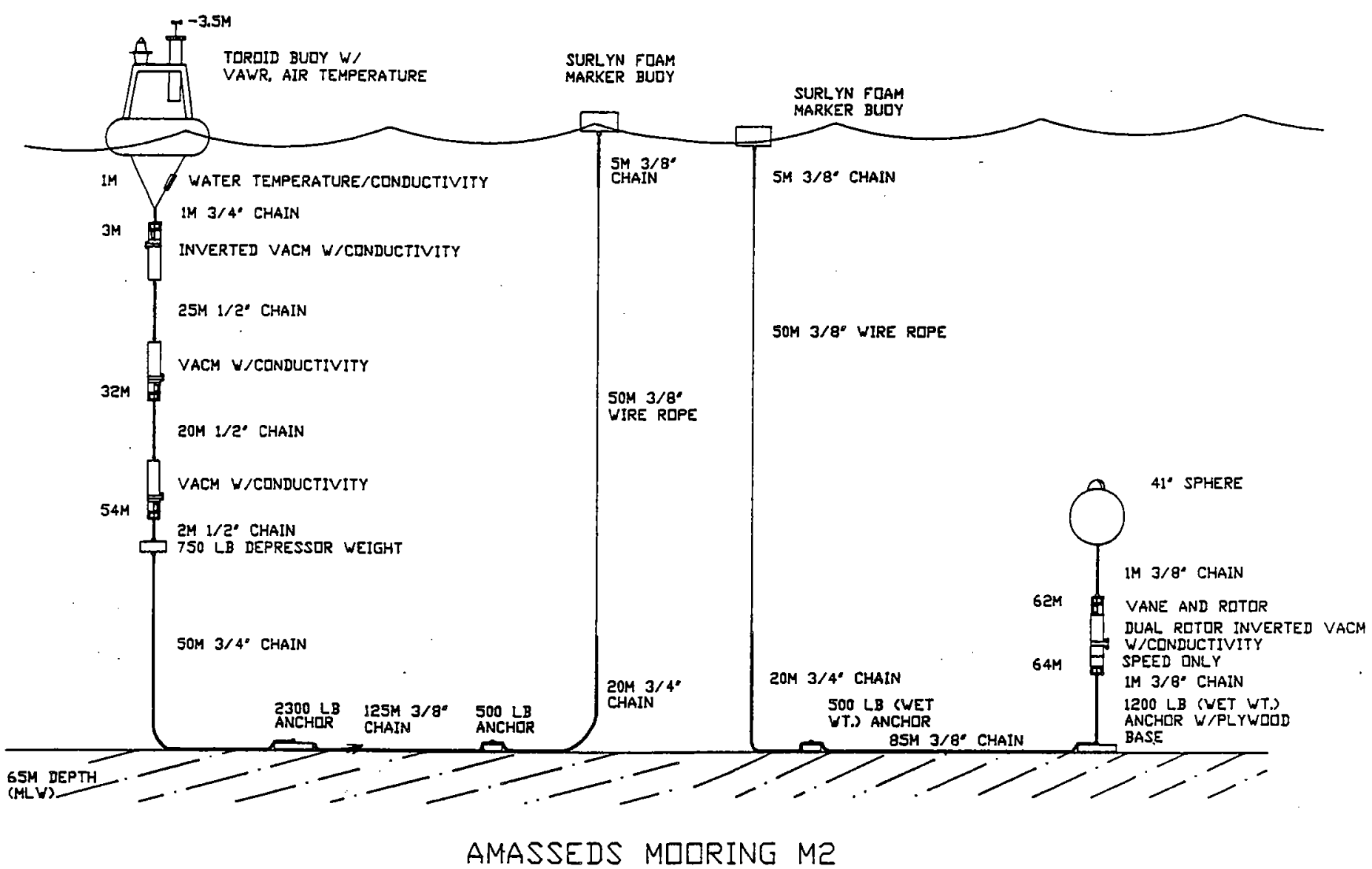

Figure 4 (cont.) 

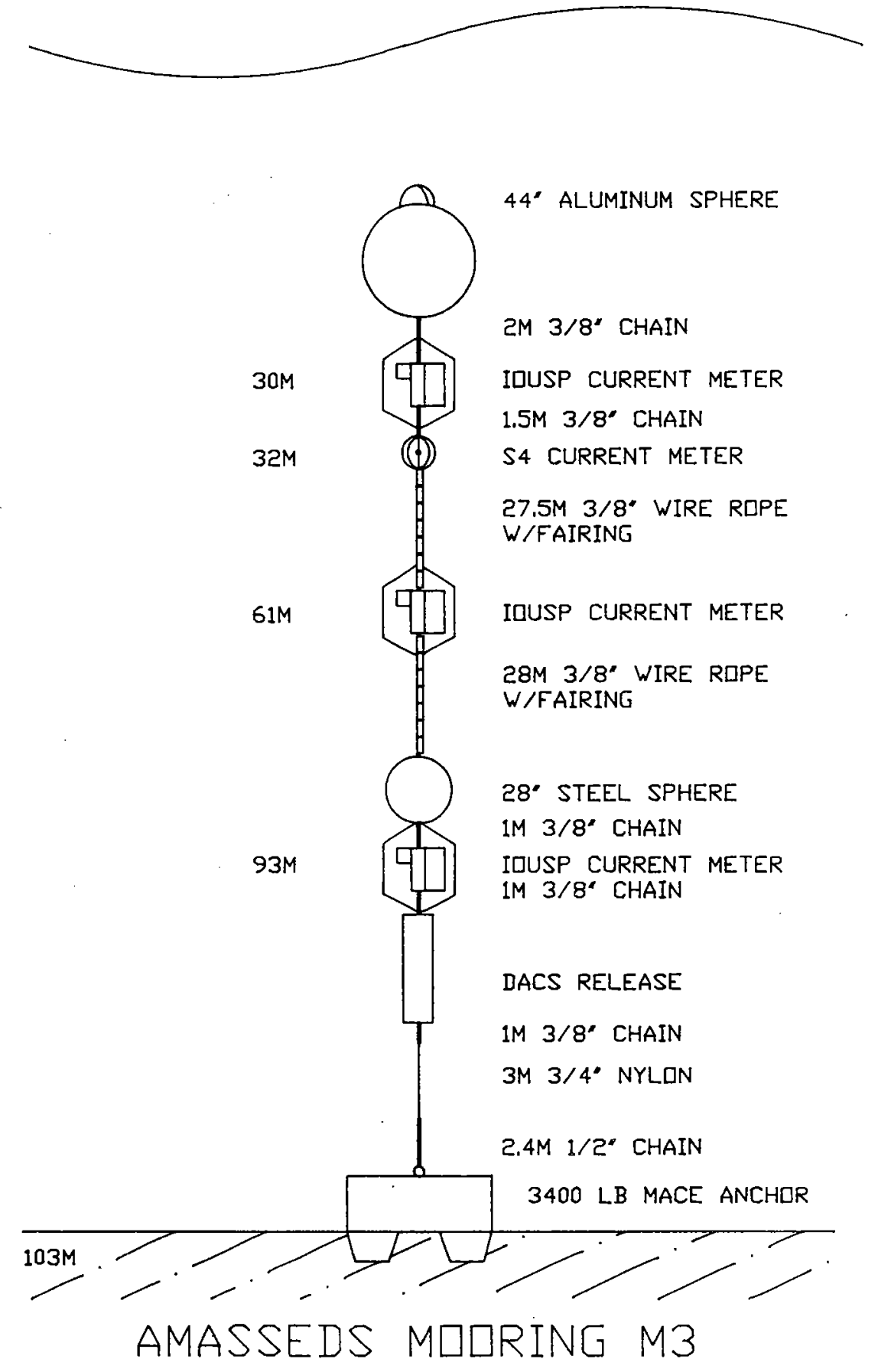

Figure 4 (cont.) 

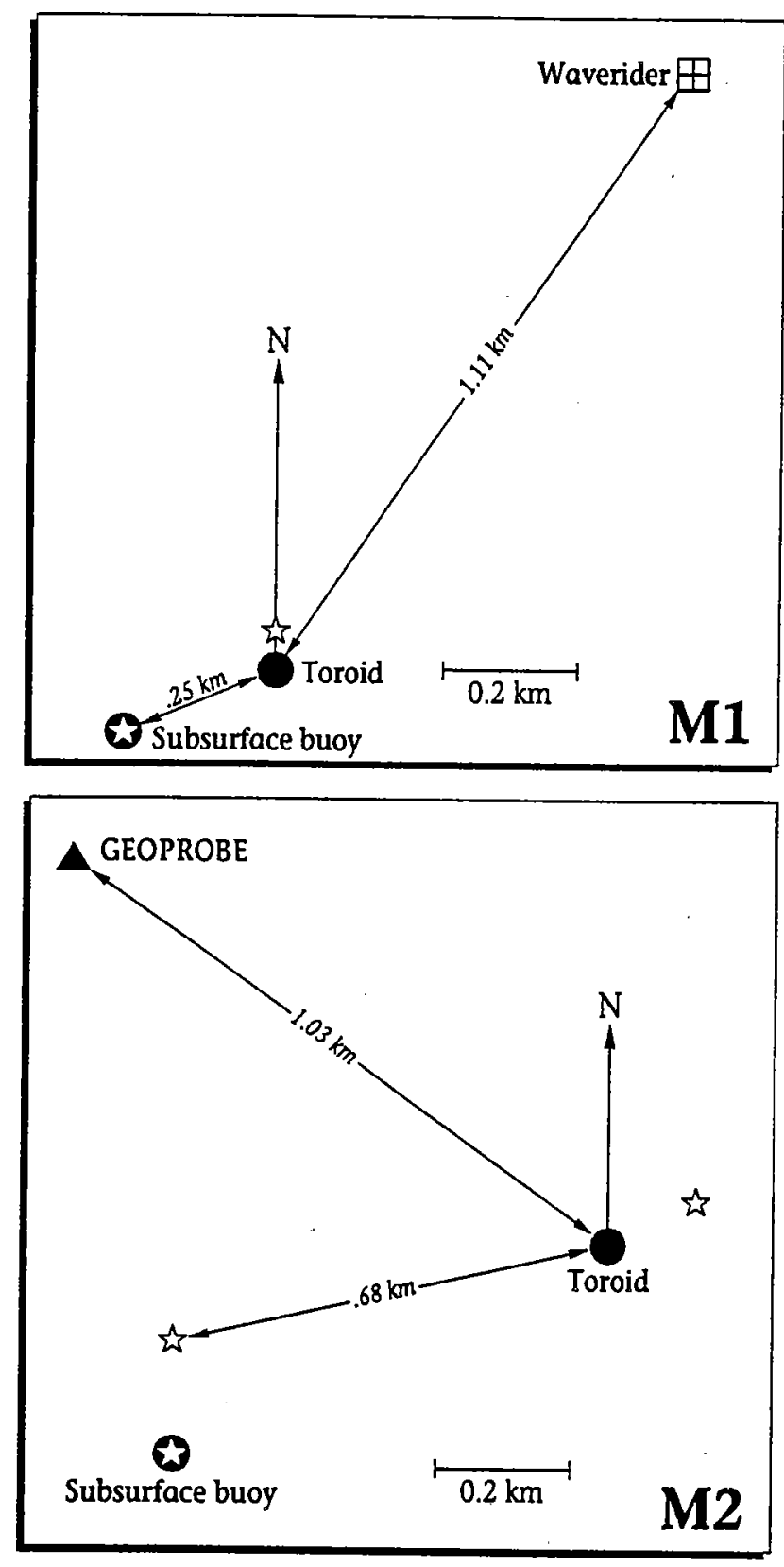

Figure 5: Relative positions of the surface and subsurface moorings at M1 (upper panel) and M2 (lower panel). The GEOPROBE is identified by ( $\mathbf{\Delta})$, surface guard buoys ( $)$, subsurface buoys $(\boldsymbol{\Theta})$, waverider $(\mathbb{\theta})$, and instrumented toroid buoys $(\boldsymbol{O})$. 
The M1 and M2 surface current meter moorings were by far the most difficult to design, prepare, and deploy. The antiquated toroid buoys which were available required extensive repair and modification, including fabrication of new rigid bridles and towers for lights and meteorological instruments. Both toroids were foam-filled in the center and decked-over which increased the total buoyancy and reduced the drag. The M1 mooring was designed for a water depth of $20 \mathrm{~m}$, supported only one current meter, and had a 750-pound depressor weight directly below the current meter to reduce the vertical tilt of the current meter. The M2 mooring was designed for a water depth of $60 \mathrm{~m}$, supported three current meters, and a compromise depressor weight of 750 pounds was used below the bottom current meter. A larger depressor weight would have reduced the tilt of the lower current meters significantly but would have risked sinking the surface buoy in the case of extreme currents. Both M1 and M2 surface moorings were set with chain ground lines to smaller secondary buoy moorings to provide a backup recovery method. In addition, both toroids were deployed with lights, radar reflectors, and WHOI-built ARGOS transmitters to monitor their positions in near-real time.

A Datawell waverider was deployed at M1 to obtain measurements of the surface gravity wave spectrum. Since the waverider buoy has very little buoyancy and would not survive or remain on the surface in the high current conditions expected at M1 if deployed in the standard way, a special mooring was designed and successfully tested in Vineyard Sound, an area where the currents reached 2.8 knots $(1.4 \mathrm{~m} / \mathrm{s})$.

\subsection{Instrumentation.}

Current, temperature, and conductivity measurements on the M1 and M2 moorings were made using WHOI Vector-Averaging Current Meters (VACMs). To measure in-situ conductivity, each VACM was equipped with a SeaBird conductivity cell mounted to the instrument case. The near surface VACMs at M1 and M2 were deployed inverted just below the rigid toroid bridle so that the current sensors were located at a depth of $3 \mathrm{~m}$. This was done to increase the likelihood that the sensors would be in the thin surface plume of low-salinity water which the hydrographic surveys revealed was typically 5 to $10 \mathrm{~m}$ thick near the moored array transect. The VACM on the M2 subsurface mooring was modified so that it had two rotors, one on either end of the case (Figure 6), in an effort to estimate bottom stress from the velocity shear. The VACMs were prepared in the standard way with 0.125-inch-diameter Kennametal 801 (a tungsten/titanium carbide) pivot/delrin block bearings. To reduce biofouling, the VACMs were completely coated with Tributyl-Tin anti-fouling paint before deployment. In addition, the conductivity cells were deployed with anti-fouling sleeves inserted in both ends of each cell. The VACMs were set to record data every 7.5 minutes. 


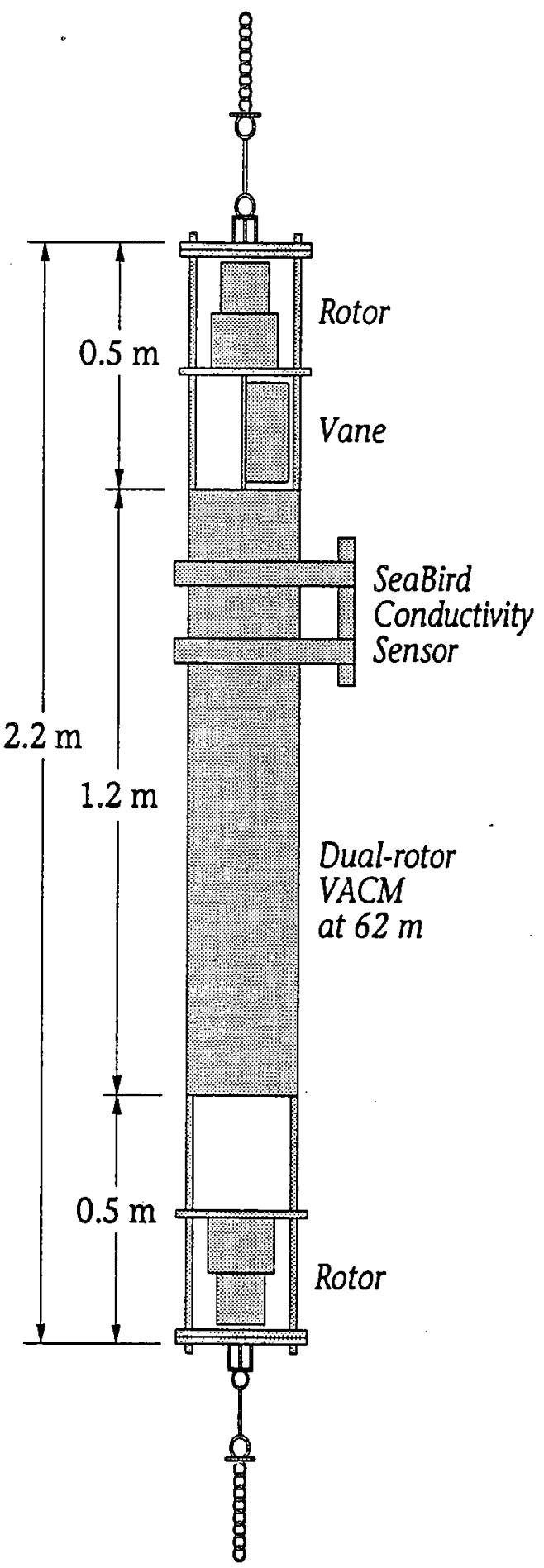

Figure 6: Schematic of the dual-rotor VACM deployed on the subsurface mooring at M2. 
Wind speed and direction were measured at $3.5 \mathrm{~m}$ above the surface on the midshelf M2 mooring using a standard WHOI Vector Averaging Wind Recorder (VAWR) mounted on the toroid buoy (Dean and Beardsley, 1988). The VAWR also recorded water temperature and conductivity data from sensors mounted at $1 \mathrm{~m}$ depth on the mooring bridle of the buoy. The VAWR was set to record average data every 7.5 minutes.

The M3 subsurface mooring supported three SD2000 current meters built in Norway by Sensordata and one WHOI InterOcean S4 current meter. The SD2000 current meter is similar to an Aanderaa current meter but smaller and more lightly built (Figure 7). The vertical strength member of the SD2000 was found to be inadequate to survive the normal mooring tension. Stainless steel cages were designed and fabricated at WHOI to pass the mooring tension around the current meter while minimizing its flow disturbance and allow the current meter to orient itself freely into the flow. The SD2000 instruments used a solid-state memory to store four-minute burst samples of vector-averaged current speed, direction, and temperature data every two hours. The SD2000 had been purchased by IOUSP as an inexpensive lightweight current meter suitable for use in shallow coastal waters. Because its performance on a subsurface mooring in a strong western boundary current was untested, an S4 current meter was deployed about $2.75 \mathrm{~m}$ below the uppermost SD2000 to provide some redundancy and data for an instrument comparison. The S4 was one in routine use at WHOI and was configured to measure and record current speed, direction and pressure every 20 minutes. A summary of the moored instrumentation and sensors deployed during AmasSeds and other descriptive information is given in Table 3.

\subsection{Deployment Strategy}

Due to the short M1 and M2 moorings, double anchor design, and high currents, the M1 and M2 surface and subsurface moorings were deployed from the R/V Iselin while she was anchored. Once the desired location was reached and the ship anchored, the instrumented section of the mooring was deployed over the side and off the stern. Then as the main anchor was being lowered on the groundline, the ship took in anchor chain so that the groundline was stretched out on the bottom into the current and the main and secondary anchors were separated as much as possible. Then the secondary surface marker buoy was released and the deployment completed. This approach worked reasonably well, although it placed great strain on the ship's anchor windlass. The M1 waverider mooring and the M3 subsurface mooring were deployed anchor last from a freely floating ship. A combination of SatNav and GPS was used for navigation. 

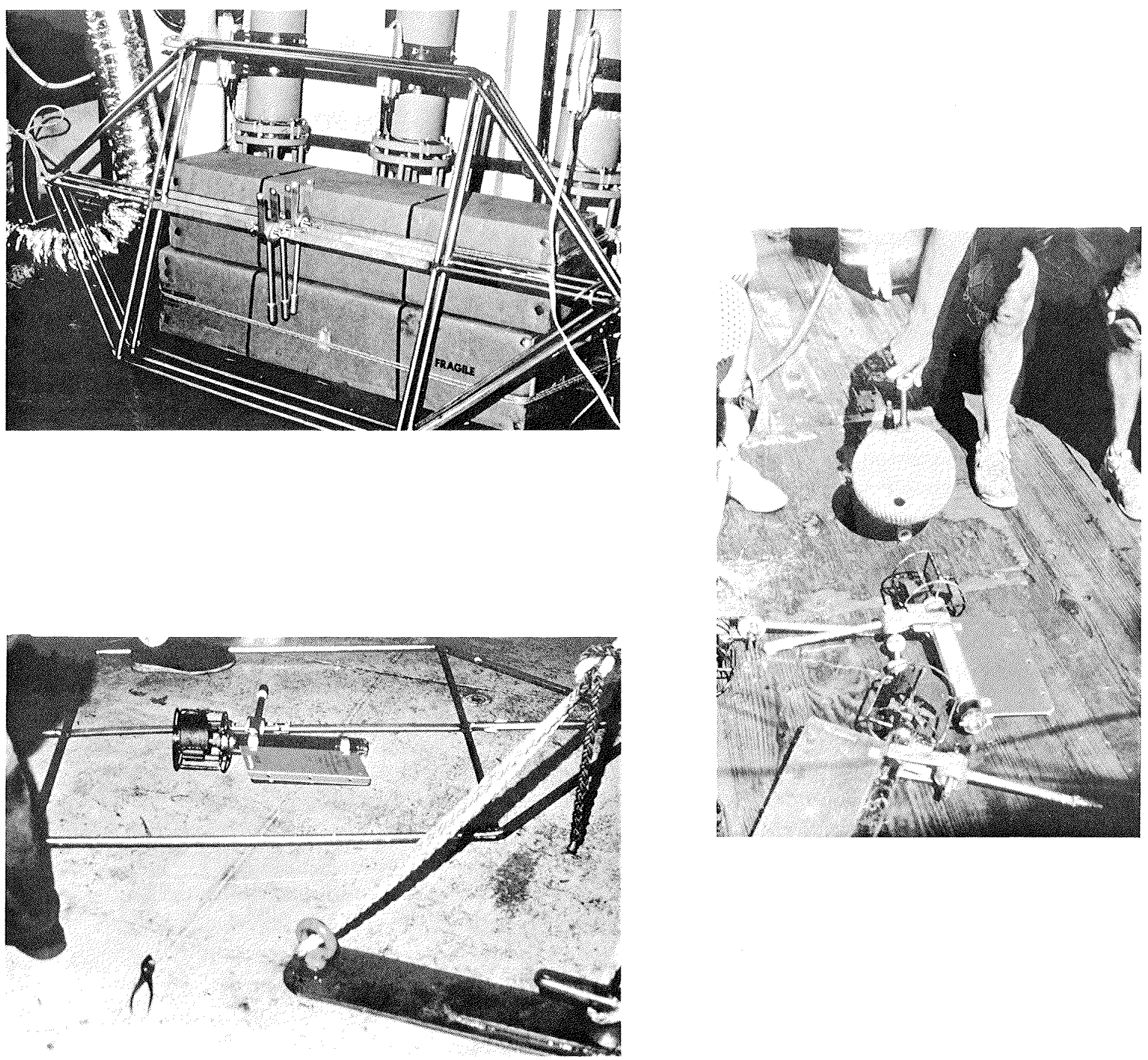

Figure 7: InterOcean S4 and the IOUSP SD2000 current meter. 
Table 3: Station information and sensors deployed during AmasSeds

\begin{tabular}{|c|c|c|c|c|c|c|c|}
\hline $\begin{array}{c}\text { Station } \\
\text { (Mooring } \\
\text { Type) }\end{array}$ & $\begin{array}{c}\text { Water } \\
\text { Depth } \\
\text { (m) }\end{array}$ & $\begin{array}{l}\text { Location } \\
\text { N/W }\end{array}$ & $\begin{array}{c}\text { Instrument } \\
\text { Sensor } \\
\text { Type }\end{array}$ & $\begin{array}{c}\text { Sensor } \\
\text { Depth } \\
\text { (m) }\end{array}$ & $\begin{array}{l}\text { Record } \\
\text { Rate } \\
\text { (min) }\end{array}$ & $\begin{array}{l}\text { Data } \\
\text { Source }\end{array}$ & $\begin{array}{r}\text { Record } \\
\text { Length } \\
\text { (days) }\end{array}$ \\
\hline $\begin{array}{c}\text { M1 } \\
\text { (Surface) }\end{array}$ & 18 & $\begin{array}{l}03^{\circ} 04.51^{\prime} \\
50^{\circ} 18.80^{\prime}\end{array}$ & $\begin{array}{c}\text { VACM(I) } \\
\text { WT } \\
\text { CD }\end{array}$ & $\begin{array}{l}3.0 \\
3.0 \\
3.0\end{array}$ & $\begin{array}{l}7.5 \\
7.5 \\
7.5\end{array}$ & WHOI & $\begin{array}{l}102 \\
128 \\
128\end{array}$ \\
\hline $\begin{array}{c}\text { M1 } \\
\text { (Subsurface) }\end{array}$ & 18 & $\begin{array}{l}03^{\circ} 04.47^{\prime} \\
50^{\circ} 18.80^{\prime}\end{array}$ & $\begin{array}{l}\text { VACM } \\
\text { WT } \\
\text { CD }\end{array}$ & $\begin{array}{l}16.0 \\
16.0 \\
16.0\end{array}$ & $\begin{array}{l}7.5 \\
7.5 \\
7.5\end{array}$ & WHOI & $\begin{array}{l}128 \\
128 \\
128\end{array}$ \\
\hline $\begin{array}{c}\text { M2 } \\
\text { (Surface) }\end{array}$ & 65 & $\begin{array}{l}03^{\circ} 23.12^{\prime} \\
49^{\circ} 56.23^{\prime}\end{array}$ & $\begin{array}{c}\text { VAWR } \\
\text { AT } \\
\text { WT } \\
\text { CD } \\
\text { VACM(I) } \\
\text { WT } \\
\text { CD } \\
\text { VACM } \\
\text { WT } \\
\text { CD } \\
\text { VACM } \\
\text { WT } \\
\text { CD }\end{array}$ & $\begin{array}{r}-3.5 \\
-3.5 \\
1.0 \\
1.0 \\
3.0 \\
3.0 \\
3.0 \\
32.0 \\
32.0 \\
32.0 \\
54.0 \\
54.0 \\
54.0\end{array}$ & $\begin{array}{l}7.5 \\
7.5 \\
7.5 \\
7.5 \\
7.5 \\
7.5 \\
7.5 \\
7.5 \\
7.5 \\
7.5 \\
7.5 \\
7.5 \\
7.5\end{array}$ & WHOI & $\begin{array}{l}23 \\
41 \\
65 \\
65 \\
65 \\
65 \\
65 \\
65 \\
65 \\
65 \\
65 \\
65 \\
65\end{array}$ \\
\hline $\begin{array}{c}\text { M2 } \\
\text { (Subsurface) }\end{array}$ & 65 & $\begin{array}{l}03^{\circ} 23.02^{\prime} \\
49^{\circ} 56.48^{\prime}\end{array}$ & $\begin{array}{c}\text { VACM(D) } \\
\text { WT } \\
\text { CD } \\
\text { PR } \\
\text { SD } \\
\text { SD }\end{array}$ & $\begin{array}{l}62.0 \\
62.0 \\
62.0 \\
62.0 \\
62.0 \\
64.0\end{array}$ & $\begin{array}{l}7.5 \\
7.5 \\
7.5 \\
7.5 \\
7.5 \\
7.5\end{array}$ & WHOI & $\begin{array}{l}128 \\
128 \\
128 \\
128 \\
128 \\
128\end{array}$ \\
\hline $\begin{array}{c}\text { M3 } \\
\text { (Subsurface) }\end{array}$ & 103 & $\begin{array}{l}04^{\circ} 04.29^{\prime} \\
49^{\circ} 37.35^{\prime}\end{array}$ & $\begin{array}{c}\text { BCM } \\
\text { WT } \\
\text { S4 } \\
\text { PR } \\
\text { BCM } \\
\text { WT } \\
\text { BCM } \\
\text { WT }\end{array}$ & $\begin{array}{l}30.0 \\
30.0 \\
32.0 \\
32.0 \\
61.0 \\
61.0 \\
93.0 \\
93.0\end{array}$ & $\begin{array}{r}120.0 \\
120.0 \\
20.0 \\
20.0 \\
120.0 \\
120.0 \\
120.0 \\
120.0\end{array}$ & $\begin{array}{l}\text { IOUSP } \\
\text { IOUSP } \\
\text { WHOI } \\
\text { WHOI } \\
\text { IOUSP } \\
\text { IOUSP } \\
\text { IOUSP } \\
\text { IOUSP }\end{array}$ & $\begin{array}{r}128 \\
128 \\
128 \\
128 \\
0 \\
128 \\
128 \\
128\end{array}$ \\
\hline
\end{tabular}

PR: Pressure CD: Conductivity AT: Air Temperature WT: Water Temperature SD: Scalar Speed S4: Inter-Ocean S4 Current Meter

BCM: Current Meters made in Norway by Sensordata, deployed by IOUSP

VACM: Vector Averaging Current Meter

VACM(I): Inverted Vector Averaging Current Meter

VACM(D): Inverted Vector Averaging Current Meter with Dual Rotors

VAWR: Vector Averaging Wind Recorder

IOUSP: Institute of Oceanography, University of Sao Paolo

WHOI: Woods Hole Oceanographic Institution 


\subsection{Mooring Recovery and Data Return}

The data return from the AmasSeds moored array is summarized in Figure 8. A number of mooring and instrument failures occurred during the mooring deployment which contributed to loss of data. An overview of these problems is given below. A complete data return resulted in about 128 days of data (Table 3 ).

The AmasSeds moored array was deployed on Leg 1 (February 8-12, 1990) of AmasSeds Cruise 2 and mostly recovered on Leg 5 (June 16-25, 1990) of Cruise 3. All mooring work was done from the R/V Iselin, which was based in Belem, Brazil during both Cruises 2 and 3. Cruise 2 contained a total of five legs over the period February 8March 30. Cruise 3 contained five legs over the period May 1-June 25. One advantage of this ship schedule was that the Iselin usually visited the M1 and M2 mooring sites at least once every leg and the surface moorings could be located and visually inspected. Within a few weeks of deployment, the M2 ARGOS transmitter stopped. On Leg 3 of Cruise 2, the transmitter package was taken to the ship and found to have a cracked housing and water inside. A new transmitter was assembled with existing and some new parts and remounted on the M2 toroid. Since it was unclear if this new transmitter would work, a Draper Lab low-cost drifter (LCD) surface buoy which contained an ARGOS transmitter was also mounted to the tower. Several LCDs were onboard to be deployed as part of the regional scale hydrographic/acoustic Doppler current profiler survey. A LCD surface buoy was also mounted on the M1 surface buoy as backup.

Only the toroid and the subsurface mooring marker buoy were found at the surface when recovery operations started at the M1 site in mid-June, 1990. The surface current was initially slack so that the ship was able to recover the subsurface mooring marker buoy first within 20 minutes without anchoring. The main anchor had about two feet of mud on top, indicating its depth of burial. The toroid and rest of the M1 mooring was successfully recovered through the ship's A-frame. Chain was present beneath the missing toroid marker buoy, suggesting it was stolen. The vertical chains of both the surface and subsurface moorings had pieces of gill nets wrapped around them, indicating a high intensity of fishing.

The M1 $3 \mathrm{~m}$ VACM was missing its rotor when it was recovered. Subsequent examination of the current data suggests the rotor failed abruptly on May 22 (101 days after deployment). The cage showed indications of the rotor rubbing or bouncing around for a period of time before the rotor broke up and its pieces flushed from the cage.

The rotor on the VACM at $16 \mathrm{~m}$ depth on the M1 subsurface mooring was out of its pivot when recovered. The rotor speed observations from this sensor did not reveal an obvious time when the sensor failed so all the data is presented in this report. However, the current speeds show a trend suggesting a gradual degradation of the speed data starting in 


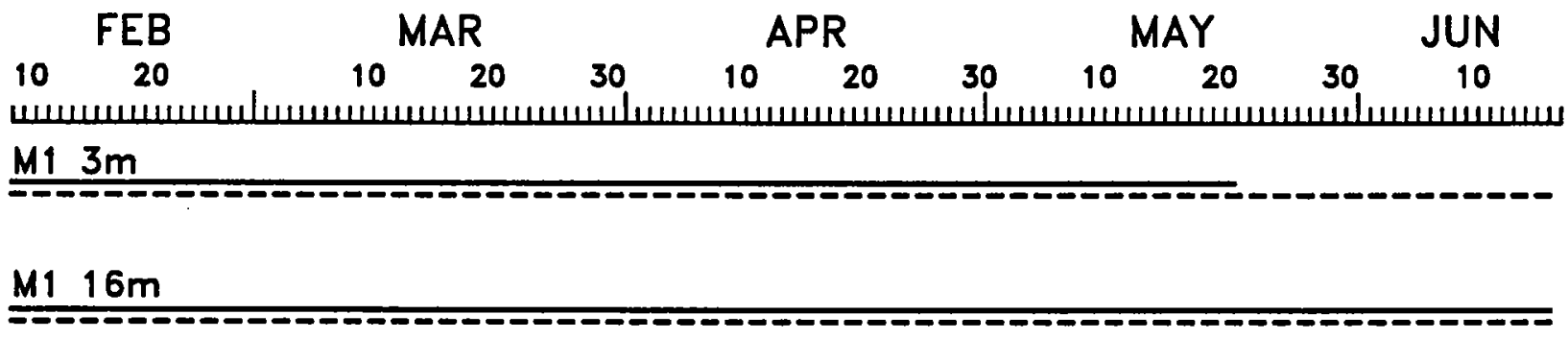

M2 Meteorological

M2 $1 \mathrm{~m}$

M2 3m

M2 $\mathrm{Jm}$ -

M2 32m

"--ー-

AmasSeds Data Return

M2 54m

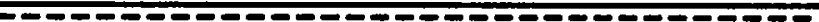

$\mathrm{M} 2.62 \mathrm{~m}$

Current or Wind

-.... Temperature and Conductivity

- Temperature only

- - Pressure

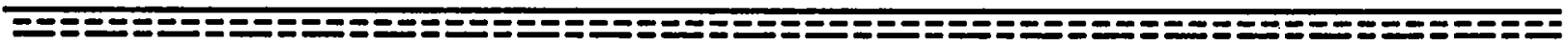

$\mathrm{M3} 30 \mathrm{~m}$

M3 32m

M3 $\underline{61}$ m

\section{M3 93m}

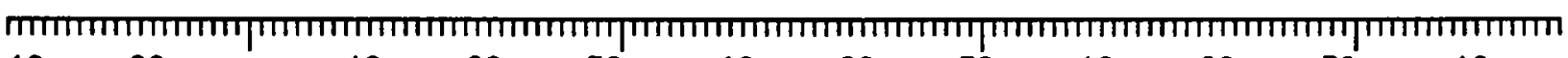

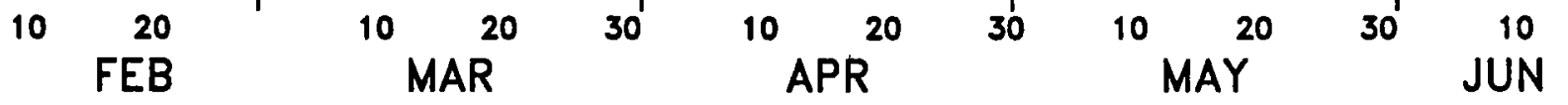

Figure 8: Data return from the AmasSeds moored array. 
mid-April. This is most likely due to the heavy growth of barnacles found over the lower part of this instrument, including the rotor, when it was recovered. Why this one VACM experienced so much biofouling is unclear, since the other current meters were relatively clean when recovered.

The special waverider mooring deployed at $\mathrm{M} 1$ was never recovered. The waverider buoy was observed to be floating at the surface in very strong currents whenever the Iselin passed the M1 site shortly into the deployment period so that that aspect of the mooring design seemed to be successful. Whether the mooring failed or the surface buoy was stolen or cut free, is not known.

The most significant problem affecting data return was the failure of the M2 surface mooring. ARGOS positioning data revealed that the M2 surface buoy began drifting on April 16, 1990 (65 days after deployment). The buoy was tracked and subsequently recovered off Suriname on April 29, 1990 aboard the R/V Iselin during its transit from Miami to Belem to start AmasSeds Cruise 3. Examination of the surface buoy revealed that the mooring failed at a shackle $1 \mathrm{~m}$ below the toroid bridle and above the first current meter. The rest of the M2 surface mooring, including all the current meters, was recovered on June 22, 1990 by dragging during the scheduled mooring recovery leg (the surface marker buoy was then missing and presumed stolen). The main anchor had at least 1.5 feet of mud on top, indicating depth of burial. The shackle linking the two sections of the mooring was not recovered so the specific cause of the mooring failure is not known. One likely candidate based on past experience in high current conditions is that the nut on the shackle worked loose and wore through the cotter pin. If the nut is not tightened enough prior to deployment, strumming of the mooring line can cause the nut to back off and vibrate enough to quickly wear out the shackle pin and cotter pin. Pieces of rope found attached to the M2 toroid (see next paragraph) and elongated chain links found in the M2 groundline also suggest that at some point prior to recovery, a fishing boat or boats hooked onto this mooring.

The M2 VAWR rotor and vane assembly were found broken off during a visit by the Iselin to the mooring site in early March. At the same time, a large rope was found tied off around the toroid tower and one leg of the tower was bent, suggesting that the tower had been 'lassoed' and used to tie up fishing boats. Consequently, the wind velocity data series was only 23 days long, ending on March 5. Because of this short wind record, ECMWF (European Centre for Medium-Range Weather Forecasts) winds were acquired to supplement the moored wind observations. A comparison of the winds at M2 and the ECMWF winds is shown in Figure 9. The VAWR air temperature sensor returned 41 days of data through March 22, and the VAWR water temperature and conductivity sensors returned full data records. 
AmasSeds M2 and ECMWF Winds $(\mathrm{m} / \mathrm{s})$
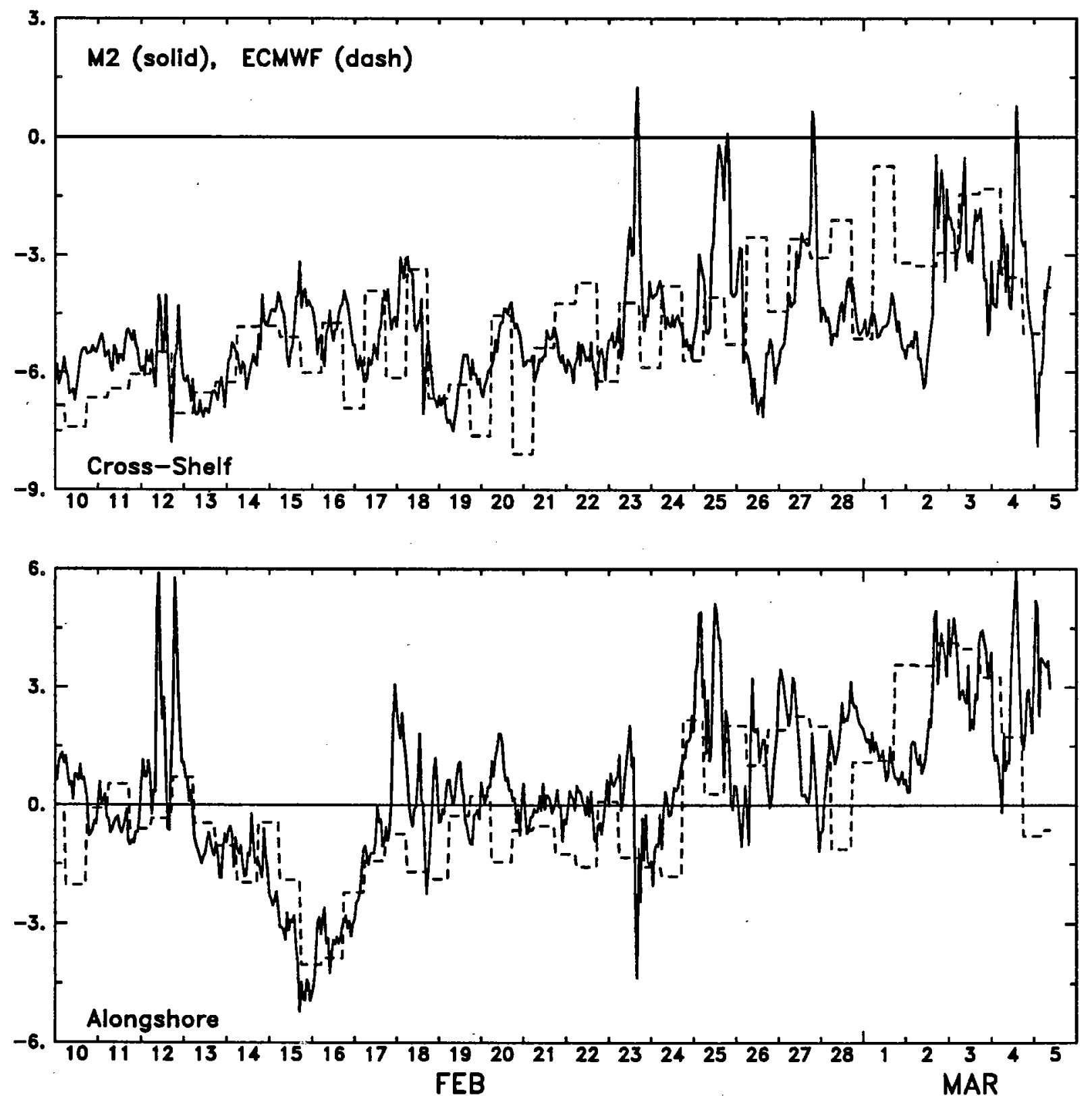

Figure 9: Time series of the hourly-averaged M2 and ECMWF wind records for 23 days. 
Attempts to recover the M2 subsurface mooring during the AmasSeds recovery cruise were unsuccessful. Its surface marker buoy was missing and even though the mooring had been deployed with good positioning data, extensive dragging did not hook the mooring. Fortunately, a Brazilian fisherman subsequently recovered this mooring on $\mathrm{Au}-$ gust 12, 1990 and the one VACM was returned to WHOI on May 8, 1991. The elongated chain links in the M2 surface mooring groundline and the extensive but unsuccessful dragging suggest that the M2 subsurface mooring was moved by fishing activity prior to the AmasSeds recovery leg. Due to the expulsion of foreign fishing vessels from French Guinea waters during the spring of 1990 , a large fleet of Brazilian and Korean shrimpers were fishing in the M2 area in late spring. During the June recovery leg, at least 10 trawlers were in sight at any time while the Iselin was working at M2.

The M3 subsurface mooring was recovered without incident. About half of the wire rope fairing was still intact. The current meters showed little biofouling and all instruments returned full data records except the $61 \mathrm{~m}$ SD2000 which returned no current data. The SD2000 current meters were in good mechanical condition including the rotors and bearings except the $61 \mathrm{~m}$ instrument which had a loose mounting shaft and the stainless steel mounting frame of the $30-\mathrm{m}$ instrument which was twisted about $45^{\circ}$ (this may have occurred during recovery).

It should be noted that the accurate determination of mean water depth at the three mooring sites was made quite difficult in this experiment by the combination of large surface tides, variations in the surface plume, variable bottom composition and bearing strength, and the presence of fluid muds and shifting sediment over the inner and mid-shelf. The water depth and instrument depths listed in Tables 3-5 represent best estimates based on a variety of inputs which include the ship's PDR data corrected for local sound speed, the moored pressure data, and the mooring configurations. The instantaneous water depth can vary from the mean by at least $\pm 1.4 \mathrm{~m}$, the maximum surface tide amplitude at the shelf break (Flagg and McDowell, 1981).

\subsection{Data Processing Methods}

Data from the M1 and M2 instruments (VAWR, VACMs) were recorded internally on standard magnetic cassette tapes and transcribed onto 9-track tapes at WHOI. The data were then converted to scientific units and edited using the standard current meter processing system developed at WHOI (Tarbell et al., 1988). This included a careful check of the timebase, truncation to remove launch and retrieval transients, the removal of erroneous data cycles, and interpolation to fill any resulting gaps in the data. 
For the M3 mooring initial decoding of the S4 current meter data was done at WHOI by R. Geyer, and final editing of the IOUSP Sensordata SD2000 current meters was done by B. Castro during a visit to WHOI in 1991. The M3 time series were truncated to a common time period and corrected for magnetic variation. An evaluation of the effects of mooring tilt on the S4 current observations and comparison of the S4 at $32 \mathrm{~m}$ and the SD2000 at $30 \mathrm{~m}$ are given in the Appendix. Time series of the hourly-averaged S4 pressure at $32 \mathrm{~m}$, which were used in the calculation to correct for dip, is shown in Figure A1.

For all vector and scalar variables that were sampled at intervals less than one hour, hourly values were formed by vector or scalar averaging (computed using a running mean), centering time on the hour (e.g., the value assigned to 1200 is an average of data collected between 1130 and 1230). Hourly averaged data for the SD2000 current meters were formed by linear interpolation between the samples recorded every two hours.

The current and wind vectors were rotated into an along-shelf coordinate system oriented $45^{\circ}$ counterclockwise with respect to true north so that the along-shelf component is positive towards $315^{\circ} \mathrm{T}$ and the cross-shelf component is positive towards $45^{\circ} \mathrm{T}$. This is also the coordinate system used in the STACS data set (Johns et al., 1990). Note that isobath orientations are roughly $325^{\circ} \mathrm{T}$ at the $\mathrm{M} 1$ mooring, $315^{\circ} \mathrm{T}$ at the $\mathrm{M} 2$ mooring and $310^{\circ} \mathrm{T}$ at the M3 mooring. The mean flow within the Amazon plume $(3 \mathrm{~m}$ depth on the $\mathrm{M} 1$ and M2 moorings) is toward $320^{\circ} \mathrm{T}$.

Salinities were estimated from the SeaBird temperature and conductivity observations using the SeaBird software.

For examining low-frequency (subtidal) variability, the hourly data were filtered using the PL64 filter. The filter is symmetric with a total of 129 weights applied to the hourly time-series. The PL64 filter has a half-power point of 38 hours. A summary of the PL64 filter, including the generating function, was given by Beardsley, Limeburner, and Rosenfeld (1985).

\section{Description of Data Presentation}

The data are presented in the form of time series plots. Each plot covers the time period between February 9, 1990 and June 22, 1990. The PL64 low-pass filtered vector plots are subsampled every six hours. For display purposes all plots are shown on two pages, side by side, with the time axis on each page spanning 66.5 days. For each variable presented, the vertical scales are generally the same but the ranges vary. The exception is salinity, where the vertical scale for M2 varies. 
Table 4: Hourly-Averaged Statistics - Entire Time Period

\begin{tabular}{|c|c|c|c|c|c|c|c|c|c|}
\hline Sta & $\begin{array}{l}\text { Water } \\
\text { Depth } \\
\text { (m) }\end{array}$ & $\begin{array}{c}\text { Start Time } \\
\text { (y m d/hm) } \\
\text { GMT }\end{array}$ & $\begin{array}{c}\text { Stop Time } \\
\text { (y m d/hm) } \\
\text { GMT }\end{array}$ & $\begin{array}{c}\text { Duration } \\
\text { (Days) }\end{array}$ & $\begin{array}{l}\text { Sensor } \\
\text { Depth } \\
\text { (m) }\end{array}$ & Mean & $\begin{array}{l}\text { Std } \\
\text { Dev }\end{array}$ & $\operatorname{Max}$ & Min \\
\hline \multicolumn{10}{|c|}{ Cross-Isobath Velocity $(\mathrm{cm} / \mathrm{s})$} \\
\hline M1 & 18 & $900209 / 1300$ & $900522 / 0500$ & 102 & 3.0 & 5.12 & 101.52 & 202.52 & -201.84 \\
\hline M1 & 18 & $900209 / 1600$ & $900617 / 1600$ & 128 & 16.0 & -0.52 & 76.61 & 185.13 & -192.59 \\
\hline M2 & 65 & $900210 / 0100$ & $900416 / 1100$ & 65 & 3.0 & 7.47 & 34.92 & 118.75 & -89.18 \\
\hline M2 & 65 & $900210 / 0100$ & $900416 / 1100$ & 65 & 32.0 & -6.01 & 35.17 & 73.10 & -81.42 \\
\hline M2 & 65 & $900210 / 0100$ & $900416 / 1100$ & 65 & 54.0 & -2.84 & 41.29 & 80.09 & -79.37 \\
\hline M2 & 65 & $900209 / 2300$ & $900618 / 1100$ & 128 & 62.0 & -6.99 & 33.57 & 77.63 & -75.39 \\
\hline M3 & 103 & $900210 / 0800$ & $900618 / 1200$ & 128 & 30.0 & 8.03 & 22.60 & 92.48 & -71.28 \\
\hline M3 & 103 & $900210 / 0800$ & $900618 / 1200$ & 128 & 32.0 & -0.32 & 25.62 & 71.72 & -78.97 \\
\hline M3 & 103 & $900210 / 0800$ & $900618 / 1200$ & 128 & 93.0 & -4.02 & 18.84 & 66.76 & -60.82 \\
\hline \multicolumn{10}{|c|}{ Along-Isobath Velocity $(\mathrm{cm} / \mathrm{s})$} \\
\hline M1 & 18 & $900209 / 1300$ & $900522 / 0500$ & 102 & 3.0 & 41.38 & 40.86 & 135.14 & -90.90 \\
\hline M1 & 18 & $900209 / 1600$ & $900617 / 1600$ & 128 & 16.0 & 6.42 & 19.58 & 89.23 & -50.18 \\
\hline M2 & 65 & $900210 / 0100$ & $900416 / 1100$ & 65 & 3.0 & 73.64 & 40.64 & 183.82 & -33.88 \\
\hline M2 & 65 & $900210 / 0100$ & $900416 / 1100$ & 65 & 32.0 & 45.76 & 14.39 & 85.69 & 9.70 \\
\hline M2 & 65 & $900210 / 0100$ & $900416 / 1100$ & 65 & 54.0 & 15.58 & 8.13 & 37.82 & -6.92 \\
\hline M2 & 65 & $900209 / 2300$ & $900618 / 1100$ & 128 & 62.0 & 10.53 & 11.85 & 47.31 & -23.04 \\
\hline M3 & 103 & $900210 / 0800$ & $900618 / 1200$ & 128 & 30.0 & 78.82 & 28.40 & 213.71 & -3.70 \\
\hline M3 & 103 & $900210 / 0800$ & $900618 / 1200$ & 128 & 32.0 & 83.59 & 26.96 & 146.64 & -7.48 \\
\hline M3 & 103 & $900210 / 0800$ & $900618 / 1200$ & 128 & 93.0 & 17.55 & 11.65 & 72.09 & -25.57 \\
\hline \multicolumn{10}{|c|}{ Water Temperature $\left({ }^{\circ} \mathrm{C}\right)$} \\
\hline M1 & 18 & $900209 / 1600$ & $900617 / 1600$ & 128 & 3.0 & 27.91 & 0.58 & 29.47 & 26.71 \\
\hline M1 & 18 & $900209 / 1600$ & $900617 / 1600$ & 128 & 16.0 & 27.27 & 0.33 & 28.40 & 26.56 \\
\hline M2 & 65 & $900210 / 0100$ & $900416 / 0900$ & 65 & 1.0 & 27.62 & 0.50 & 29.21 & 26.63 \\
\hline M2 & 65 & $900210 / 0100$ & $900416 / 1100$ & 65 & 3.0 & 27.62 & 0.48 & 29.20 & 26.66 \\
\hline M2 & 65 & $900210 / 0100$ & $900416 / 1100$ & 65 & 32.0 & 26.85 & 0.38 & 27.69 & 25.31 \\
\hline M2 & 65 & $900210 / 0100$ & $900416 / 1100$ & 65 & 54.0 & 26.04 & 0.98 & 27.48 & 23.89 \\
\hline M2 & 65 & $900209 / 2300$ & $900811 / 1000$ & 128 & 62.0 & 26.42 & 1.09 & 27.70 & 23.69 \\
\hline M3 & 103 & $900210 / 0800$ & $900618 / 1200$ & 128 & 30.0 & 28.31 & 0.52 & 29.76 & 26.89 \\
\hline M3 & 103 & $900210 / 0800$ & $900618 / 1200$ & 128 & 61.0 & 27.50 & 0.54 & 28.63 & 24.68 \\
\hline M3 & 103 & $900210 / 0800$ & $900618 / 1200$ & 128 & 93.0 & 24.34 & 2.09 & 28.13 & 17.78 \\
\hline \multicolumn{10}{|c|}{ Conductivity (s/m) } \\
\hline M1 & 18 & $900209 / 1600$ & $900617 / 1600$ & 128 & 3.0 & 3.31 & 0.78 & 5.24 & 1.35 \\
\hline M1 & 18 & $900209 / 1600$ & $900617 / 1600$ & 128 & 16.0 & 5.03 & 0.49 & 5.66 & 2.97 \\
\hline M2 & 65 & $900210 / 0100$ & $900416 / 0900$ & 65 & 1.0 & 4.21 & 0.93 & 5.74 & 1.89 \\
\hline M2 & 65 & $900210 / 0100$ & $900416 / 1100$ & 65 & 3.0 & 4.40 & 0.85 & 5.74 & 2.11 \\
\hline M2 & 65 & $900210 / 0100$ & $900416 / 1100$ & 65 & 32.0 & 5.67 & 0.04 & 5.77 & 5.49 \\
\hline M2 & 65 & $900210 / 0100$ & $900416 / 1100$ & 65 & 54.0 & 5.59 & 0.10 & 5.75 & 5.36 \\
\hline M2 & 65 & $900209 / 2300$ & $900618 / 1100$ & 128 & 62.0 & 5.55 & 0.10 & 5.72 & 5.30 \\
\hline \multicolumn{10}{|c|}{ Salinity (psu) } \\
\hline M1 & 18 & $900209 / 1600$ & $900617 / 1600$ & 128 & 3.0 & 19.56 & 5.13 & 32.71 & 7.28 \\
\hline M1 & 18 & $900209 / 1600$ & $900617 / 1600$ & 128 & 16.0 & 31.43 & 3.49 & 35.87 & 17.34 \\
\hline M2 & 65 & $900210 / 0100$ & $900416 / 0900$ & 65 & 1.0 & 25.69 & 6.41 & 36.34 & 10.76 \\
\hline M2 & 65 & $900210 / 0100$ & $900416 / 1100$ & 65 & 3.0 & 26.92 & 5.86 & 36.34 & 11.89 \\
\hline M2. & 65 & $900210 / 0100$ & $900416 / 1100$ & 65 & 32.0 & 36.23 & 0.09 & 36.41 & 34.95 \\
\hline M2 & 65 & $900210 / 0100$ & $900416 / 1100$ & 65 & 54.0 & 36.24 & 0.03 & 36.35 & 36.15 \\
\hline M2 & 65 & $900209 / 2300$ & $900618 / 1100$ & 128 & 62.0 & 36.00 & 0.13 & 36.24 & 35.54 \\
\hline
\end{tabular}


Table 4: Hourly-Averaged Statistics - Entire Time Period

\begin{tabular}{|c|c|c|c|c|c|c|c|c|c|}
\hline Sta & $\begin{array}{l}\text { Water } \\
\text { Depth } \\
\text { (m) }\end{array}$ & $\begin{array}{c}\text { Start Time } \\
(y \mathrm{~m} \mathrm{~d} / \mathrm{hm}) \\
\text { GMT }\end{array}$ & $\begin{array}{c}\text { Stop Time } \\
(\mathrm{y} \mathrm{m} \mathrm{d/hm)} \\
\text { GMT }\end{array}$ & $\begin{array}{c}\text { Duration } \\
\text { (Days) }\end{array}$ & $\begin{array}{c}\text { Sensor } \\
\text { Depth } \\
\text { (m) }\end{array}$ & Mean & $\begin{array}{l}\text { Std } \\
\text { Dev }\end{array}$ & $\operatorname{Max}$ & Min \\
\hline \multicolumn{10}{|c|}{ Air Temperature $\left({ }^{\circ} \mathrm{C}\right)$} \\
\hline M2 & 65 & $900210 / 0100$ & $900322 / 1900$ & 41 & -3.5 & 26.66 & 0.86 & 28.09 & 23.18 \\
\hline \multicolumn{10}{|c|}{ Cross-Isobath Wind (m/s) } \\
\hline $\begin{array}{l}\text { M2 } \\
\text { EW }\end{array}$ & $\begin{array}{l}65 \\
-\end{array}$ & $\begin{array}{l}900210 / 0100 \\
900209 / 0000\end{array}$ & $\begin{array}{l}900305 / 0900 \\
900618 / 2300\end{array}$ & $\begin{array}{r}23 \\
130\end{array}$ & -3.5 & $\begin{array}{l}-4.82 \\
-4.30\end{array}$ & $\begin{array}{l}1.47 \\
1.73\end{array}$ & $\begin{array}{l}1.25 \\
0.20\end{array}$ & $\begin{array}{l}-7.88 \\
-8.28\end{array}$ \\
\hline \multicolumn{10}{|c|}{ Along-Isobath Wind (m/s) } \\
\hline $\begin{array}{l}\text { M2 } \\
\text { EW }\end{array}$ & $\begin{array}{c}65 \\
-\end{array}$ & $\begin{array}{l}900210 / 0100 \\
900209 / 0000\end{array}$ & $\begin{array}{l}900305 / 0900 \\
900618 / 2300\end{array}$ & $\begin{array}{r}23 \\
130\end{array}$ & $\begin{array}{r}-3.5 \\
-\end{array}$ & $\begin{array}{l}0.45 \\
0.86\end{array}$ & $\begin{array}{l}2.00 \\
1.65\end{array}$ & $\begin{array}{l}5.96 \\
4.52\end{array}$ & $\begin{array}{l}-5.21 \\
-4.02\end{array}$ \\
\hline \multicolumn{10}{|c|}{ 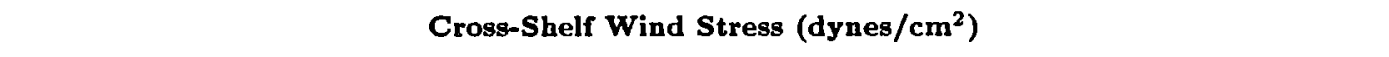 } \\
\hline $\begin{array}{l}\text { M2 } \\
\text { EW }\end{array}$ & $\begin{array}{c}65 \\
-\end{array}$ & $\begin{array}{l}900210 / 0100 \\
900209 / 0000\end{array}$ & $\begin{array}{l}900305 / 0900 \\
900618 / 2300\end{array}$ & $\begin{array}{r}23 \\
130\end{array}$ & $\begin{array}{r}-3.5 \\
-\end{array}$ & $\begin{array}{r}-0.49 \\
-0.42\end{array}$ & $\begin{array}{l}0.21 \\
0.27\end{array}$ & $\begin{array}{l}0.10 \\
0.00\end{array}$ & $\begin{array}{r}-1.34 \\
-1.27\end{array}$ \\
\hline \multicolumn{10}{|c|}{ Alongshore Wind Stress (dynes $/ \mathrm{cm}^{2}$ ) } \\
\hline $\begin{array}{l}\text { M2 } \\
\text { EW }\end{array}$ & $\begin{array}{l}65 \\
-\end{array}$ & $\begin{array}{l}900210 / 0100 \\
900209 / 0000\end{array}$ & $\begin{array}{l}900305 / 0900 \\
900618 / 2300\end{array}$ & $\begin{array}{r}23 \\
130\end{array}$ & $\begin{array}{r}-3.5 \\
-\end{array}$ & $\begin{array}{l}0.04 \\
0.07\end{array}$ & $\begin{array}{l}0.21 \\
0.16\end{array}$ & $\begin{array}{l}0.85 \\
0.51\end{array}$ & $\begin{array}{r}-0.58 \\
-0.53\end{array}$ \\
\hline \multicolumn{10}{|c|}{ Pressure (db) } \\
\hline $\begin{array}{l}\text { M2 } \\
\text { M3 }\end{array}$ & $\begin{array}{c}65 \\
103\end{array}$ & $\begin{array}{l}900209 / 2300 \\
900210 / 0800\end{array}$ & $\begin{array}{l}900618 / 1100 \\
900618 / 1200\end{array}$ & $\begin{array}{l}129 \\
128\end{array}$ & $\begin{array}{l}62.0 \\
32.0\end{array}$ & $\begin{array}{l}59.85 \\
34.97\end{array}$ & $\begin{array}{l}0.88 \\
1.96\end{array}$ & $\begin{array}{l}62.25 \\
43.99\end{array}$ & $\begin{array}{l}57.60 \\
30.30\end{array}$ \\
\hline \multicolumn{10}{|c|}{ Scalar Speed $(\mathrm{cm} / \mathrm{s})$} \\
\hline $\begin{array}{l}\text { M2 } \\
\text { M2 }\end{array}$ & $\begin{array}{l}65 \\
65\end{array}$ & $\begin{array}{l}900209 / 2300 \\
900209 / 2300\end{array}$ & $\begin{array}{l}900618 / 2200 \\
900618 / 2200\end{array}$ & $\begin{array}{l}129 \\
129\end{array}$ & $\begin{array}{l}62.0 \\
64.0\end{array}$ & $\begin{array}{l}35.36 \\
29.53\end{array}$ & $\begin{array}{l}14.64 \\
11.58\end{array}$ & $\begin{array}{l}85.46 \\
73.64\end{array}$ & $\begin{array}{l}6.88 \\
6.23\end{array}$ \\
\hline
\end{tabular}

Note: EW = European Centre for Medium-Range Weather Forecasts 
Table 5: Hourly-Averaged Statistics - Common Time Period

\begin{tabular}{|c|c|c|c|c|c|c|c|c|c|}
\hline Sta & $\begin{array}{l}\text { Water } \\
\text { Depth } \\
(\mathrm{m})\end{array}$ & $\begin{array}{c}\text { Start Time } \\
(y \mathrm{~m} \mathrm{~d} / \mathrm{hm}) \\
\text { GMT }\end{array}$ & $\begin{array}{c}\text { Stop Time } \\
\text { (y m d/hm) } \\
\text { GMT }\end{array}$ & $\begin{array}{c}\text { Duration } \\
\text { (Days) }\end{array}$ & $\begin{array}{l}\text { Sensor } \\
\text { Depth } \\
\text { (m) }\end{array}$ & Mean & $\begin{array}{l}\text { Std } \\
\text { Dev }\end{array}$ & $\operatorname{Max}$ & Min \\
\hline \multicolumn{10}{|c|}{ Cross-Isobath Vèlocity $(\mathrm{cm} / \mathrm{s})$} \\
\hline M1 & 18 & $900210 / 0800$ & $900416 / 0900$ & 65 & 3.0 & 3.09 & 107.27 & 202.52 & -201.84 \\
\hline M1 & 18 & $900210 / 0800$ & $900416 / 0900$ & 65 & 16.0 & 0.04 & 93.25 & 185.13 & -192.59 \\
\hline M2 & 65 & $900210 / 0800$ & $900416 / 0900$ & 65 & 3.0 & 7.41 & 34.90 & 118.75 & -89.18 \\
\hline M2 & 65 & $900210 / 0800$ & $900416 / 0900$ & 65 & 32.0 & -5.98 & 35.12 & 73.10 & -81.42 \\
\hline M2 & 65 & $900210 / 0800$ & $900416 / 0900$ & 65 & 54.0 & -2.84 & 41.20 & 80.09 & -79.37 \\
\hline M2 & 65 & $900210 / 0800$ & $900416 / 0900$ & 65 & 62.0 & -4.62 & 35.31 & 82.07 & -74.93 \\
\hline M3 & 103 & $900210 / 0800$ & $900416 / 0900$ & 65 & 30.0 & 8.77 & 19.11 & 77.28 & -50.46 \\
\hline M3 & 103 & $900210 / 0800$ & $900416 / 0900$ & 65 & 32.0 & -0.14 & 29.14 & 75.00 & -82.59 \\
\hline M3 & 103 & $900210 / 0800$ & $900416 / 0900$ & 65 & 93.0 & -4.77 & 19.07 & 66.76 & -56.34 \\
\hline \multicolumn{10}{|c|}{ Along-Isobath Velocity $(\mathrm{cm} / \mathrm{s})$} \\
\hline M1 & 18 & $900210 / 0800$ & $900416 / 0900$ & 65 & 3.0 & 38.21 & 45.18 & 135.14 & -90.90 \\
\hline M1 & 18 & $900210 / 0800$ & $900416 / 0900$ & 65 & 16.0 & 8.24 & 24.07 & 89.23 & -43.52 \\
\hline M2 & 65 & $900210 / 0800$ & $900416 / 0900$ & 65 & 3.0 & 73.77 & 40.60 & 183.82 & -33.88 \\
\hline M2 & 65 & $900210 / 0800$ & $900416 / 0900$ & 65 & 32.0 & 45.68 & 14.30 & 83.15 & 9.70 \\
\hline M2 & 65 & $900210 / 0800$ & $900416 / 0900$ & 65 & 54.0 & 15.56 & 8.13 & 37.82 & -6.92 \\
\hline M2 & 65 & $900210 / 0800$ & $900416 / 0900$ & 65 & 62.0 & 12.84 & 8.05 & 34.21 & -7.73 \\
\hline M3 & 103 & $900210 / 0800$ & $900416 / 0900$ & 65 & 30.0 & 70.33 & 15.92 & 122.83 & 16.58 \\
\hline M3 & 103 & $900210 / 0800$ & $900416 / 0900$ & 65 & 32.0 & 95.52 & 21.76 & 157.71 & 16.38 \\
\hline M3 & 103 & $900210 / 0800$ & $900416 / 0900$ & 65 & 93.0 & 19.63 & 10.20 & 51.53 & -2.67 \\
\hline \multicolumn{10}{|c|}{ Water Temperature $\left({ }^{\circ} \mathrm{C}\right)$} \\
\hline M1 & 18 & $900210 / 0800$ & $900416 / 0900$ & 65 & 3.0 & 27.51 & 0.46 & 28.86 & 26.71 \\
\hline M1 & 18 & $900210 / 0800$ & $900416 / 0900$ & 65 & 16.0 & 27.10 & 0.27 & 28.10 & 26.56 \\
\hline M2 & 65 & $900210 / 0800$ & $900416 / 0900$ & 65 & 1.0 & 27.62 & 0.50 & 29.21 & 26.63 \\
\hline M2 & 65 & $900210 / 0800$ & $900416 / 0900$ & 65 & 3.0 & 27.62 & 0.48 & 29.20 & 26.66 \\
\hline M2 & 65 & $900210 / 0800$ & $900416 / 0900$ & 65 & 32.0 & 26.85 & 0.38 & 27.69 & 25.31 \\
\hline M2 & 65 & $900210 / 0800$ & $900416 / 0900$ & 65 & 54.0 & 26.04 & 0.98 & 27.48 & 23.89 \\
\hline M2 & 65 & $900210 / 0800$ & $900416 / 0900$ & 65 & 62.0 & 25.99 & 1.03 & 27.49 & 23.89 \\
\hline M3 & 103 & $900210 / 0800$ & $900416 / 0900$ & 65 & 30.0 & 27.96 & 0.46 & 29.30 & 26.89 \\
\hline M3 & 103 & $900210 / 0800$ & $900416 / 0900$ & 65 & 61.0 & 27.25 & 0.43 & 28.21 & 24.68 \\
\hline M3 & 103 & $900210 / 0800$ & $900416 / 0900$ & 65 & 93.0 & 24.61 & 1.79 & 27.29 & 19.23 \\
\hline \multicolumn{10}{|c|}{ Conductivity (s/m) } \\
\hline M1 & 18 & $900210 / 0800$ & $900416 / 0900$ & 65 & 3.0 & 3.29 & 0.72 & 4.92 & 1.70 \\
\hline M1 & 18 & $900210 / 0800$ & $900416 / 0900$ & 65 & 16.0 & 4.92 & 0.50 & 5.59 & 2.97 \\
\hline M2 & 65 & $900210 / 0800$ & $900416 / 0900$ & 65 & 1.0 & 4.21 & 0.93 & 5.74 & 1.89 \\
\hline M2 & 65 & $900210 / 0800$ & $900416 / 0900$ & 65 & 3.0 & 4.40 & 0.85 & 5.74 & 2.11 \\
\hline M2 & 65 & $900210 / 0800$ & $900416 / 0900$ & 65 & 32.0 & 5.67 & 0.04 & 5.77 & 5.49 \\
\hline M2 & 65 & $900210 / 0800$ & $900416 / 0900$ & 65 & 54.0 & 5.59 & 0.10 & 5.75 & 5.36 \\
\hline M2 & 65 & $900210 / 0800$ & $900416 / 0900$ & 65 & 62.0 & 5.56 & 0.10 & 5.72 & 5.35 \\
\hline \multicolumn{10}{|c|}{ Salinity (psu) } \\
\hline M1 & 18 & $900210 / 0800$ & $900416 / 0900$ & 65 & 3.0 & 19.58 & 4.82 & 30.74 & 9.30 \\
\hline M1 & 18 & $900210 / 0800$ & $900416 / 0900$ & 65 & 16.0 & 30.73 & 3.56 & 35.31 & 17.34 \\
\hline M2 & 65 & $900210 / 0800$ & $900416 / 0900$ & 65 & 1.0 & 25.66 & 6.40 & 36.34 & 10.76 \\
\hline M2 & 65 & $900210 / 0800$ & $900416 / 0900$ & 65 & 3.0 & 26.90 & 5.85 & 36.34 & 11.89 \\
\hline M2 & 65 & $900210 / 0800$ & $900416 / 0900$ & 65 & 32.0 & 36.23 & 0.09 & 36.41 & 34.95 \\
\hline M2 & 65 & $900210 / 0800$ & $900416 / 0900$ & 65 & 54.0 & 36.24 & 0.03 & 36.35 & 36.18 \\
\hline M2 & 65 & $900210 / 0800$ & $900416 / 0900$ & 65 & 62.0 & 36.09 & 0.07 & 36.23 & 35.93 \\
\hline
\end{tabular}


Table 5: Hourly-Averaged Statistics - Common Time Period (continued)

\begin{tabular}{|c|c|c|c|c|c|c|c|c|c|}
\hline Sta & $\begin{array}{l}\text { Water } \\
\text { Depth } \\
(\mathbf{m})\end{array}$ & $\begin{array}{c}\text { Start Time } \\
\text { (y m d/hm) } \\
\text { GMT }\end{array}$ & $\begin{array}{c}\text { Stop Time } \\
\text { (y m d/hm) } \\
\text { GMT }\end{array}$ & $\begin{array}{c}\text { Duration } \\
\text { (Days) }\end{array}$ & $\begin{array}{c}\text { Sensor } \\
\text { Depth } \\
\text { (m) }\end{array}$ & Mean & $\begin{array}{l}\text { Std } \\
\text { Dev }\end{array}$ & $\operatorname{Max}$ & Min \\
\hline \multicolumn{10}{|c|}{ Pressure (db) } \\
\hline M2 & 65 & $900210 / 0800$ & $900416 / 0900$ & 65 & 62.0 & 60.17 & 0.87 & 62.25 & 58.02 \\
\hline M3 & 103 & $900210 / 0800$ & $900416 / 0900$ & 65 & 32.0 & 35.37 & 1.43 & 40.08 & 32.26 \\
\hline \multicolumn{10}{|c|}{ Scalar Speed $(\mathrm{cm} / \mathrm{s})$} \\
\hline M2 & 65 & $900210 / 0800$ & $900416 / 0900$ & 65 & 62.0 & 36.18 & 14.93 & 85.46 & 8.69 \\
\hline M2 & 65 & $900210 / 0800$ & $900416 / 0900$ & 65 & 64.0 & 29.80 & 11.56 & 73.64 & 6.84 \\
\hline \multicolumn{10}{|c|}{ Cross-Isobath Wind $(\mathrm{m} / \mathrm{s})$} \\
\hline EW & - & $900210 / 0800$ & $900416 / 0900$ & 65 & - & -5.17 & 1.52 & -0.73 & -8.28 \\
\hline \multicolumn{10}{|c|}{ Along-Isobath Wind $(\mathrm{m} / \mathrm{s})$} \\
\hline EW & - & $900210 / 0800$ & $900416 / 0900$ & 65 & - & 0.29 & 1.64 & 4.14 & -4.02 \\
\hline \multicolumn{10}{|c|}{ Cross-Shelf Wind Stress (dynes/cm ${ }^{2}$ ) } \\
\hline EW & - & $900210 / 0800$ & $900416 / 0900$ & 65 & - & -0.55 & 0.27 & -0.02 & -1.27 \\
\hline \multicolumn{10}{|c|}{ Alongshore Wind Stress(dynes $/ \mathrm{cm}^{2}$ ) } \\
\hline EW & - & $900210 / 0800$ & $900416 / 0900$ & 65 & - & 0.02 & 0.17 & 0.51 & -0.53 \\
\hline
\end{tabular}

Note: $\mathrm{EW}=$ European Centre for Medium-Range Weather Forecasts 
The basic statistics for the hourly averaged data covering the entire period for each record are shown in Table 4. To facilitate comparisons, Table 5 shows the statistics for the common 65-day time period when most sensors worked, 0800 February $10-0900$ April 16, 1990 (GMT).

The hourly-averaged air temperature at M2 and the M2 and ECMWF winds are shown in Figure 10. Composite (stacked) plots of the PL64 low-pass filtered currents are presented in Figures 11-16. The time-series for each instrument have been stacked vertically on the same time base for easy comparison. Composite plots of the hourlyaveraged current velocity components are shown in Figures 17-20.

Composite (overlay) plots of the PL64 low-pass filtered water temperature and salinity records by mooring are presented in Figures 21 and 22. Composite (stacked) plots of the hourly-averaged individual water temperature, salinity, and conductivity time series records are shown in Figures 23-29. Time series of the hourly-averaged and PL64 low-pass filtered speed records from the dual rotor VACM are shown in Figure 30. The hourly-averaged pressure record at M2 is shown in Figure 31.

\section{Acknowledgments}

The authors would like to express their appreciation to the many individuals who helped to make the AmasSeds moored array field program successful. In particular, we would like to acknowledge Sean Kery, Peter Clay, and Dave Simoneau for their work in designing and fabricating the moorings, Scott Worrilow and Bryan Way for preparing and debriefing the VAWR and VACMs and conductivity cells, and Susan Tarbell who read and edited the VAWR and VACM data. Dick Limeburner made several unscheduled visits to the M1 and M2 toroids, one to recover the broken M2 VAWR wind sensors and another to recover the failed ARGOS transmitter and mount the Draper Lab LCDs as backup ARGOS transmitters. The deployment crew consisted of Dave Simoneau, Scott Worrilow, Pat O'Malley, John Trowbridge, Belmiro Castro, and Bob Beardsley. The recovery crew consisted of Dave Simoneau, Scott Worrilow, Peter Clay, Belmiro Castro, Dick Limeburner, and Bob Beardsley. Additional help during the extensive dragging operations was given by George Tate and Joanne Theade (USGS), and Dick Sternberg (University of Washington). We also want to acknowledge the fine job of ship handling done by the officers and crew of the R/V Iselin during the moored array deployment and recovery operations.

George Tupper and Brian Racine did the mooring model calculations presented in the Appendix, and Anne-Marie Michael helped prepare the final version of this report.

The U.S. component of the AmasSeds moored array field program was supported by NSF Grant OCE $88-12917$. The Brazilian mooring work at M3 was supported by 
FAPESP grant $89 / 3508-4$. The preparation and publication of this report is funded by NSF grant OCE 91-15712.

\section{References}

AmasSeds Research Group (1990). A Multidisciplinary Amazon Shelf SEDiment Study. Eos Transactions, American Geophysical Union, 71, 45, November 6, 1990.

Beardsley, R. C., R. Limeburner, and L. K. Rosenfeld, 1985. Introduction to CODE-2 Moored Array and Large-Scale Data Report. Woods Hole Oceanographic Institution Technical Report, WHOI-85-35, CODE Technical Report No. 38, 234 pp.

Dean, J. P., and R. C. Beardsley, 1988. A vector-averaging wind recorder (VAWR) system for surface meteorological measurements in CODE (Coastal Ocean Dynamics Experiment). Woods Hole Oceanographic Institution Technical Report WHOI-88-20, $77 \mathrm{pp}$.

Flagg, C. N., and S. McDowell, 1981. Current and hydrographic measurements of the North Brazil coastal current between $2^{\circ}$ and $7^{\circ} \mathrm{N}$ latitude. EG\&G Environmental Consultants. Submitted to Esso Exploration, Inc., August.

Geyer, W. R., R. C. Beardsley, J. Candela, B. Castro, R. V. Legeckis, S. J. Lentz, R. Limeburner, L. Miranda, and J. H. Trowbridge, 1991. The physical oceanography of the Amazon outflow. Oceanography, 4, 8-14.

Gibbs, R. J., 1972. Water chemistry of the Amazon River. Geochimica et Cosmochimica Acta, 36, 1061-1066.

Johns, W. E., R. L. Molinari, and D. Wilson, 1990. International research activities in the tropical Atlantic Ocean off northern Brazil. Eos, Transactions of the American Geophysical Union, 71, 43 (abstract).

Kuehl, S. A., D. J. DeMaster, and C. A. Nittrouer, 1986. Nature of sediment accumulation on the Amazon continental shelf. Continental Shelf Research, 6, 209-225.

Limeburner, R., and R. C. Beardsley, 1989. CTD observations off northern Brazil during A Multidisciplinary Amazon Shelf SEDiment Study, AmasSeds, August, 1989. Woods Hole Oceanographic Institution Technical Report, WHOI-89-53, 134 pp.

Limeburner, R., and R. C. Beardsley, 1991a. CTD observations off northern Brazil during A Multidisciplinary Amazon Shelf SEDiment Study, AmasSeds, February - March, 1990. Woods Hole Oceanographic Institution Technical Report, WHOI-91-11, 344 pp. 
Limeburner, R., and R. C. Beardsley, 1991b. CTD observations off northern Brazil during A Multidisciplinary Amazon Shelf SEDiment Study, AmasSeds, May - June 1990. Woods Hole Oceanographic Institution Technical Report, WHOI-91-12, 344 pp.

Limeburner, R., I. D. Soares, J. Candela, and R. C. Beardsley, 1992. CTD observations on the North Brazil Shelf during A Multidisciplinary Amazon Shelf SEDiment Study (AMASSEDS), November 1991. Woods Hole Oceanographic Institution Technical Report, WHOI-92-27, 257 pp.

Meade, R. H., T. Dunne, J. E. Richey, U. De M. Sanots, and E. Salati, 1985. Storage and remobilization of suspended sediment in the lower Amazon River of Brazil. Science, 228, 488-490.

Milliman, J. D., and R. H. Meade, 1983. World-wide delivery of river sediment to the oceans. Journal of Geology, 91, 1-21.

Moller, D., 1976. A computer program for the design and static analysis of single-point subsurface mooring systems: NOYFB. Woods Hole Oceanographic Institution Technical Report, WHOI-76-59, 105 pp.

Nittrouer, C. A. (Editor) 1991. Oceanography, The Oceanography Society, Vol. 4, No. 1, $47 \mathrm{pp}$.

Oltman, R. E., 1968. Reconnaissance investigations of the discharge and water quality of the Amazon River. U.S. Geological Survey, Circular 552, Washington, D.C., 16 pp.

Philander, S. G. H., and R. C. Pacanowski, 1986: The mass and heat budget in a model of the tropical Atlantic Ocean. Journal of Geophysical Research, 91, 14,212-14,220.

Picaut, J., J. Servain, P. Lecompte, M. Seva, S. Lukas, and G. Rougier, 1985. Climatic Atlas of the Tropical Atlantic Wind Stress and Sea Surface Temperature, 1964-1979. Université de Bretagne Occidentale, 467 pp.

Tarbell, S. A., A. Spencer, and E. T. Montgomery, 1988. The Buoy Group Data Processing System. Woods Hole Oceanographic Institution Technical Memorandum, WHOI3-88, 207 pp. 


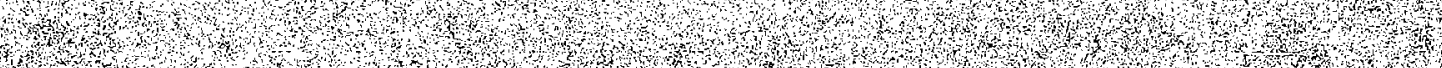

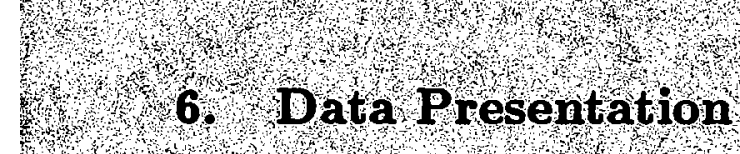
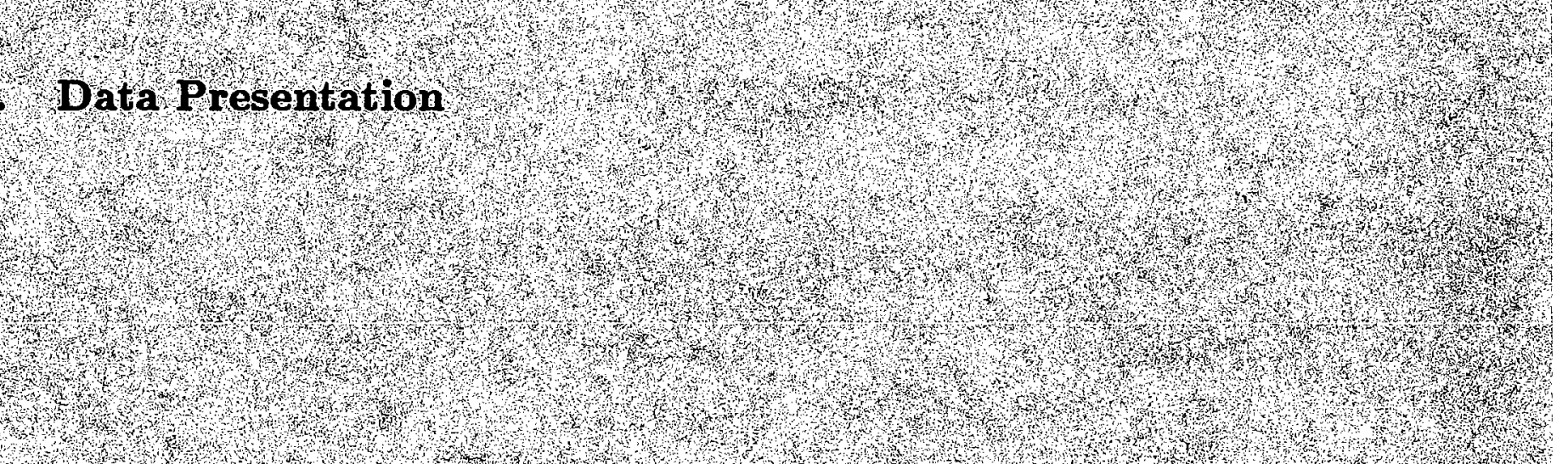


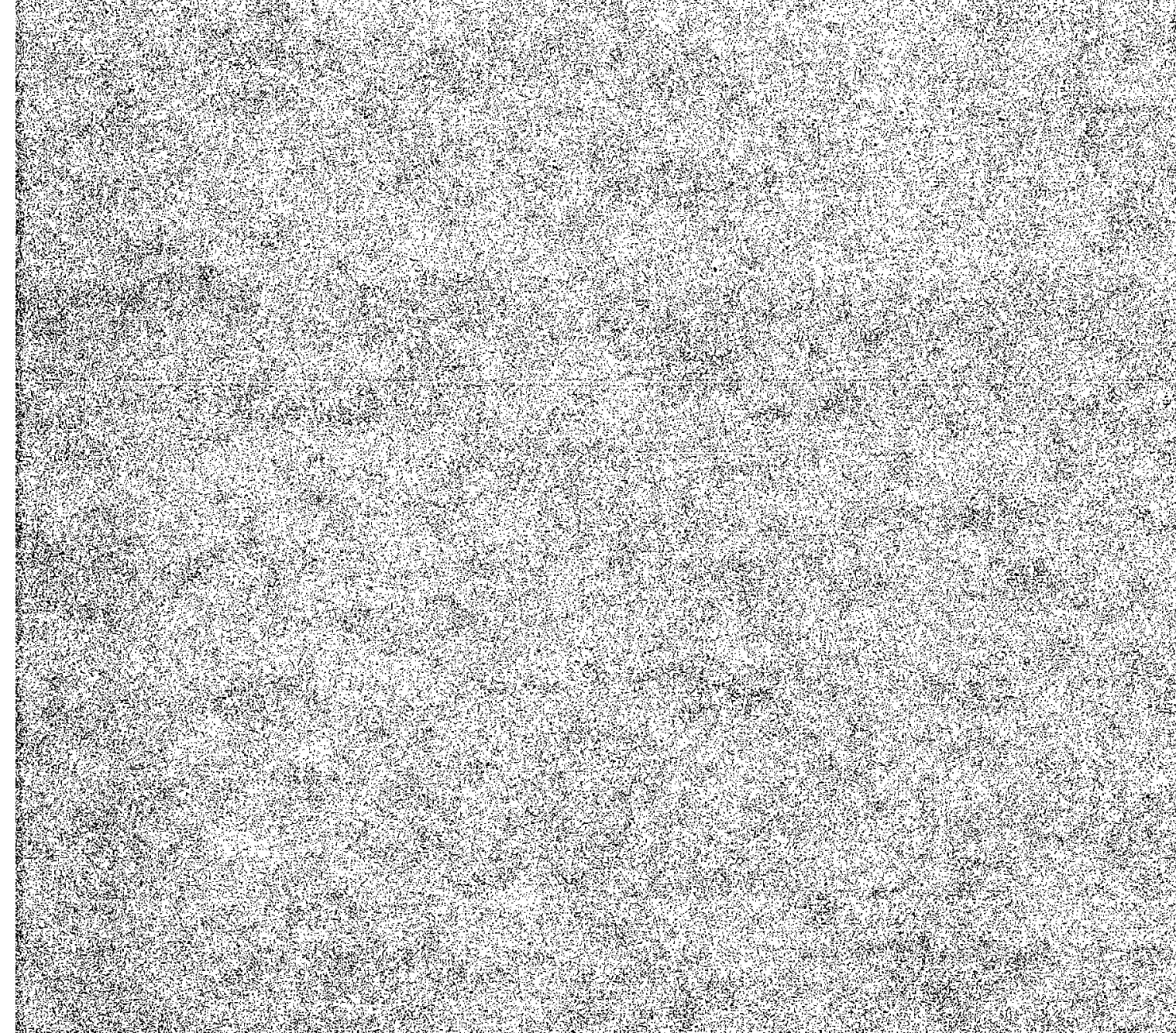

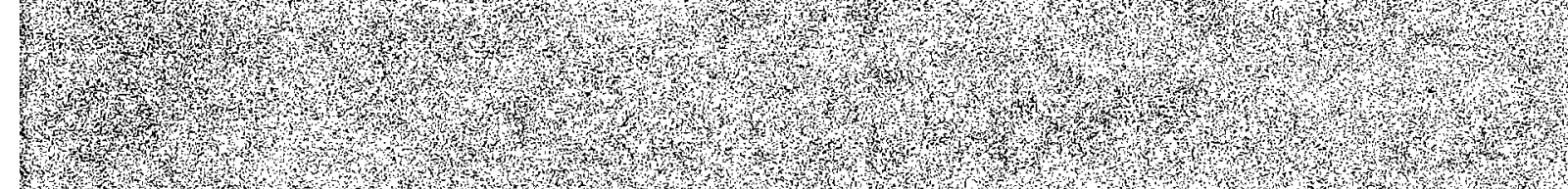


M2 and ECMWF Winds $(\mathrm{m} / \mathrm{s})$
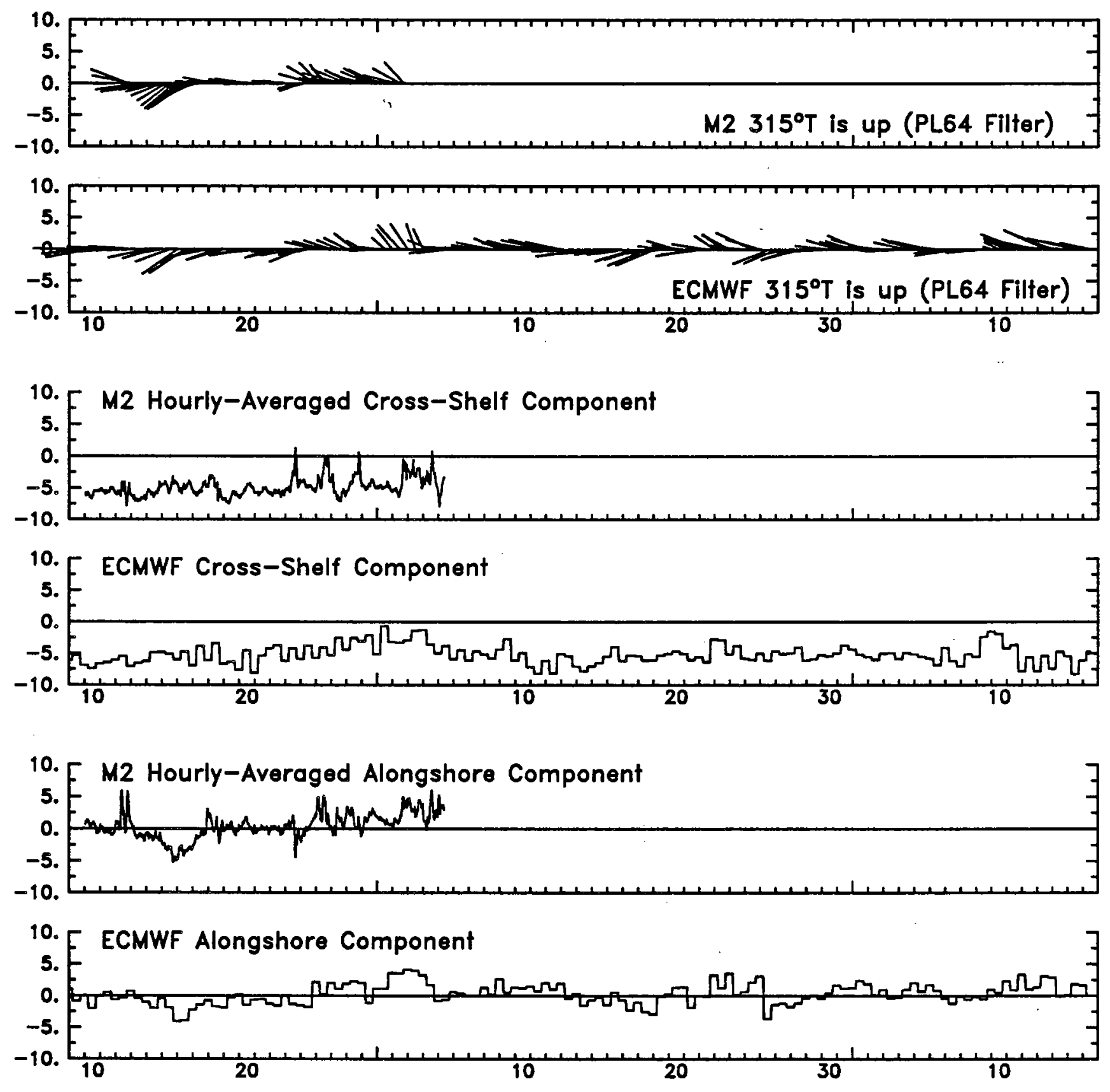

Hourly-Averaged Air Temperature at M2

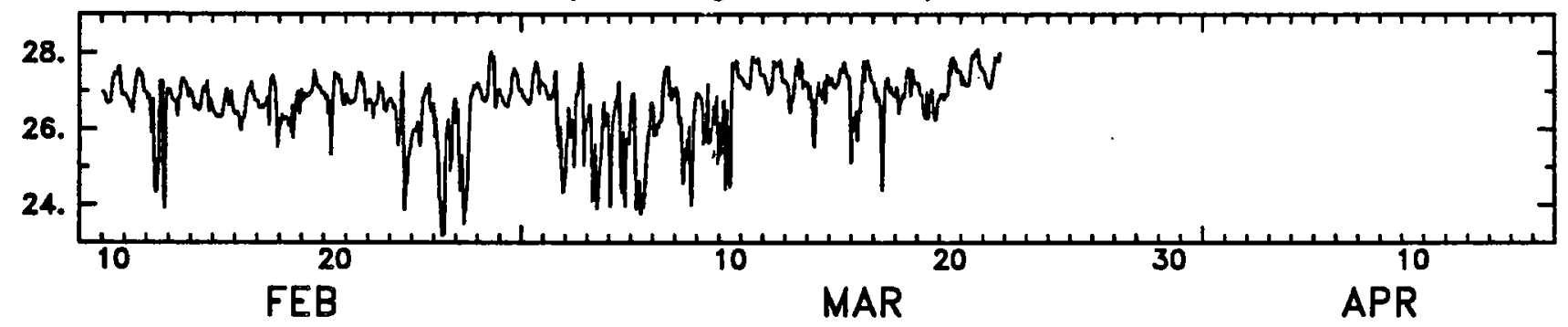




\section{M2 and ECMWF Winds $(\mathrm{m} / \mathrm{s})$}
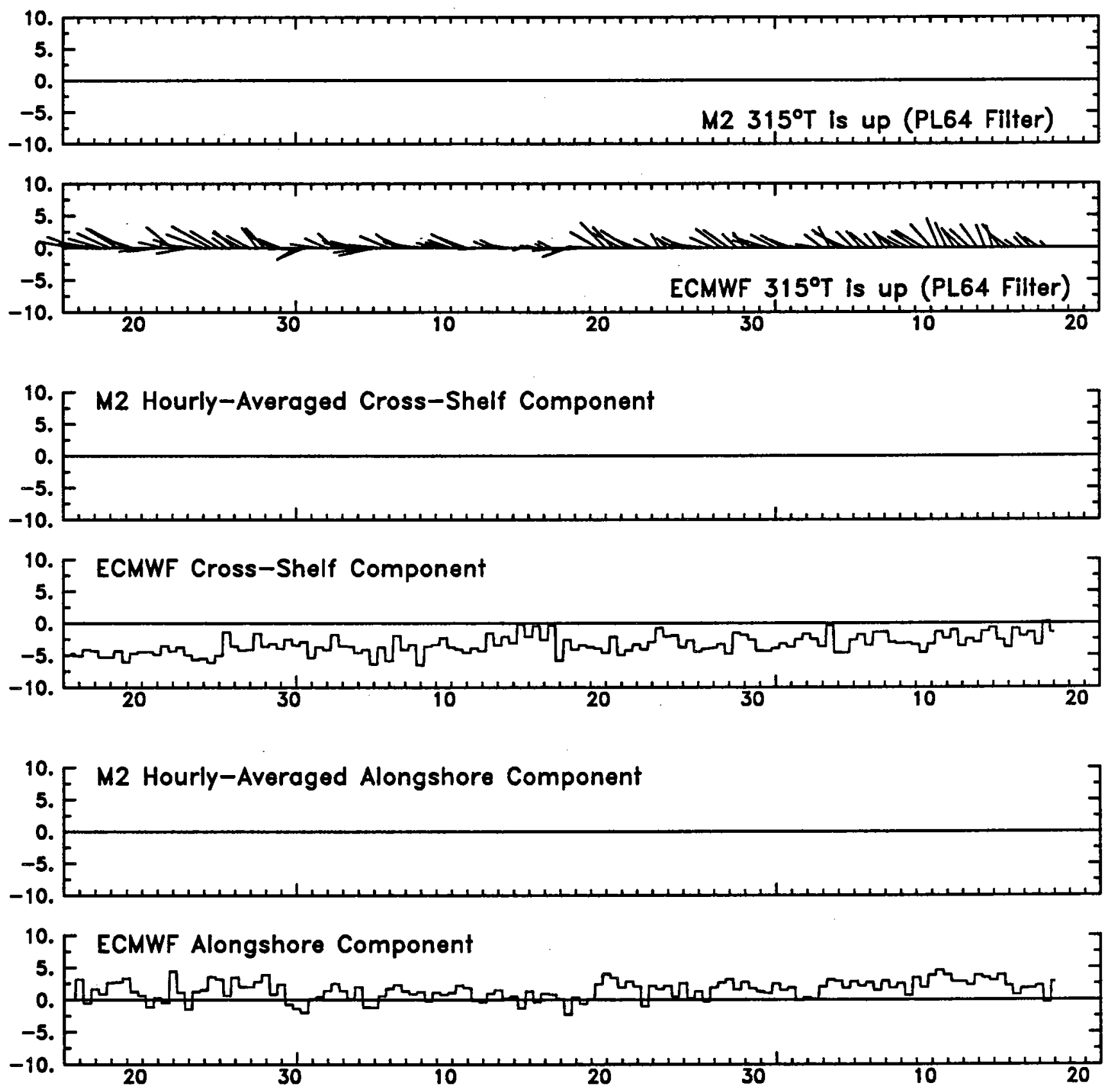

Hourly-Averaged Air Temperature at M2

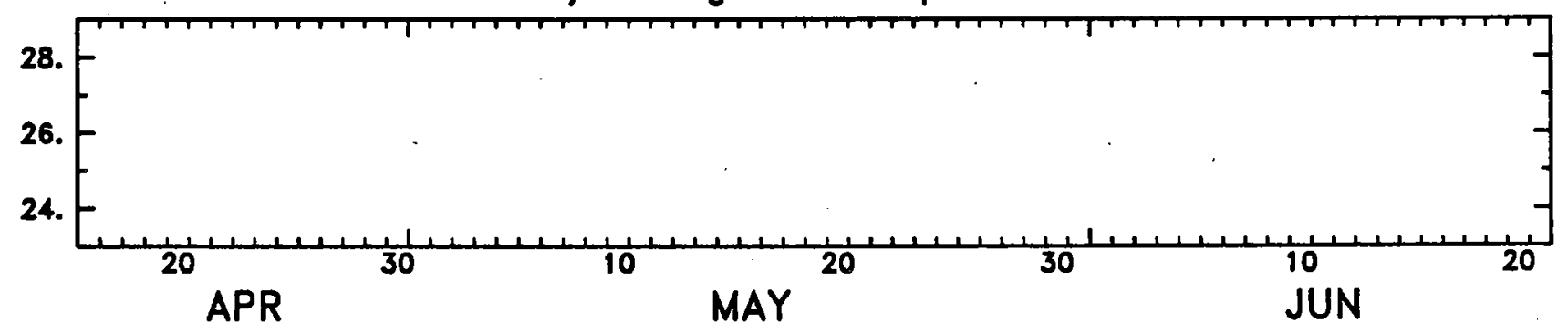


PL64 Low-Pass Filtered Currents $(\mathrm{cm} / \mathrm{s})$ at $M 1$ and $M 2$

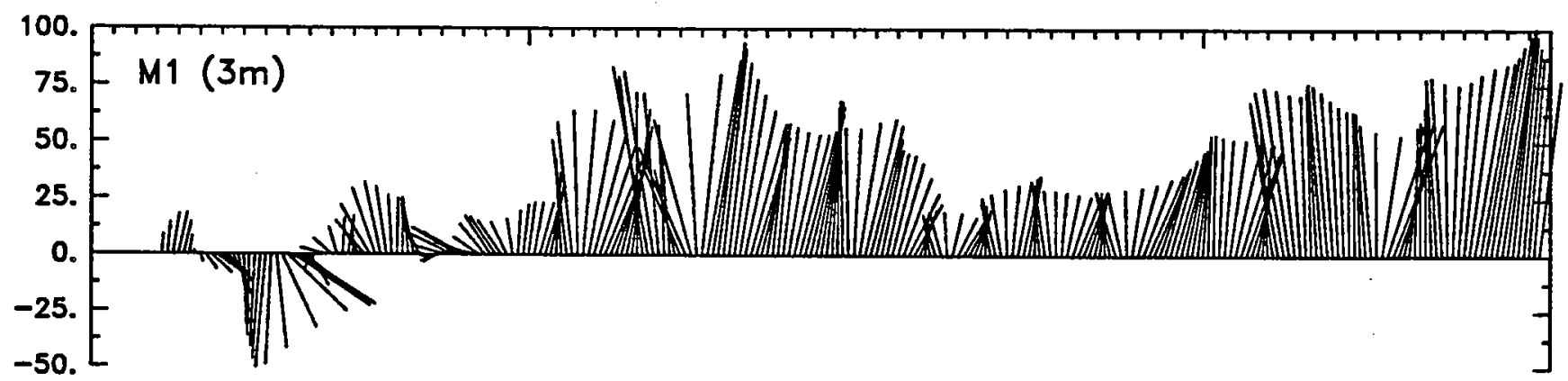

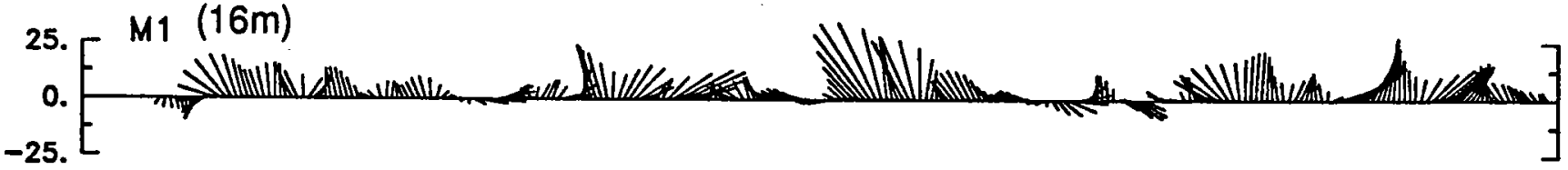

175. [

(3m)

150.

75. $\mathrm{M} 2(32 \mathrm{~m})$

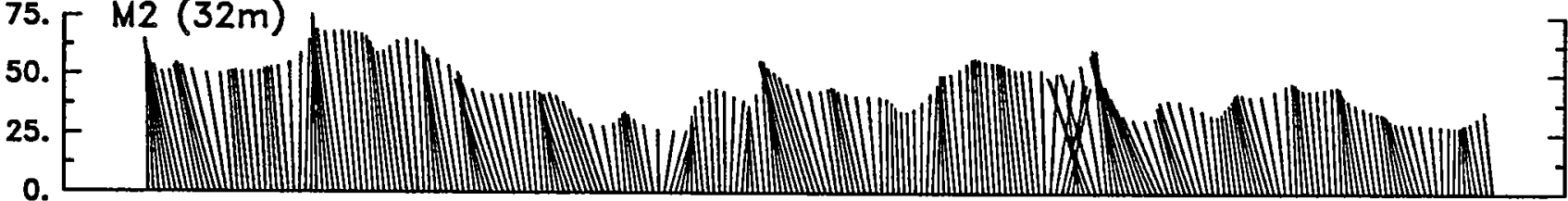

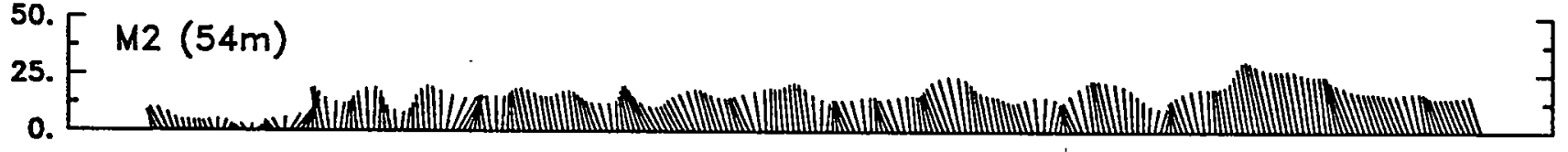

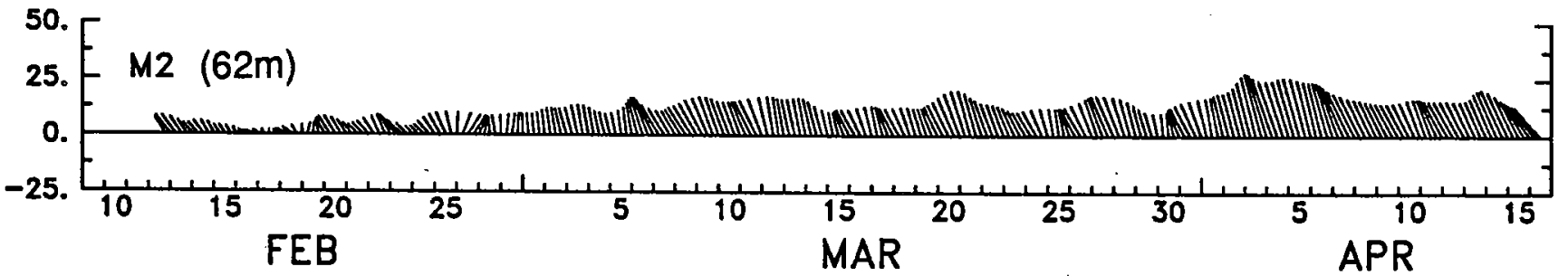


PL64 Low-Pass Filtered Currents $(\mathrm{cm} / \mathrm{s})$ at $M 1$ and $M 2$
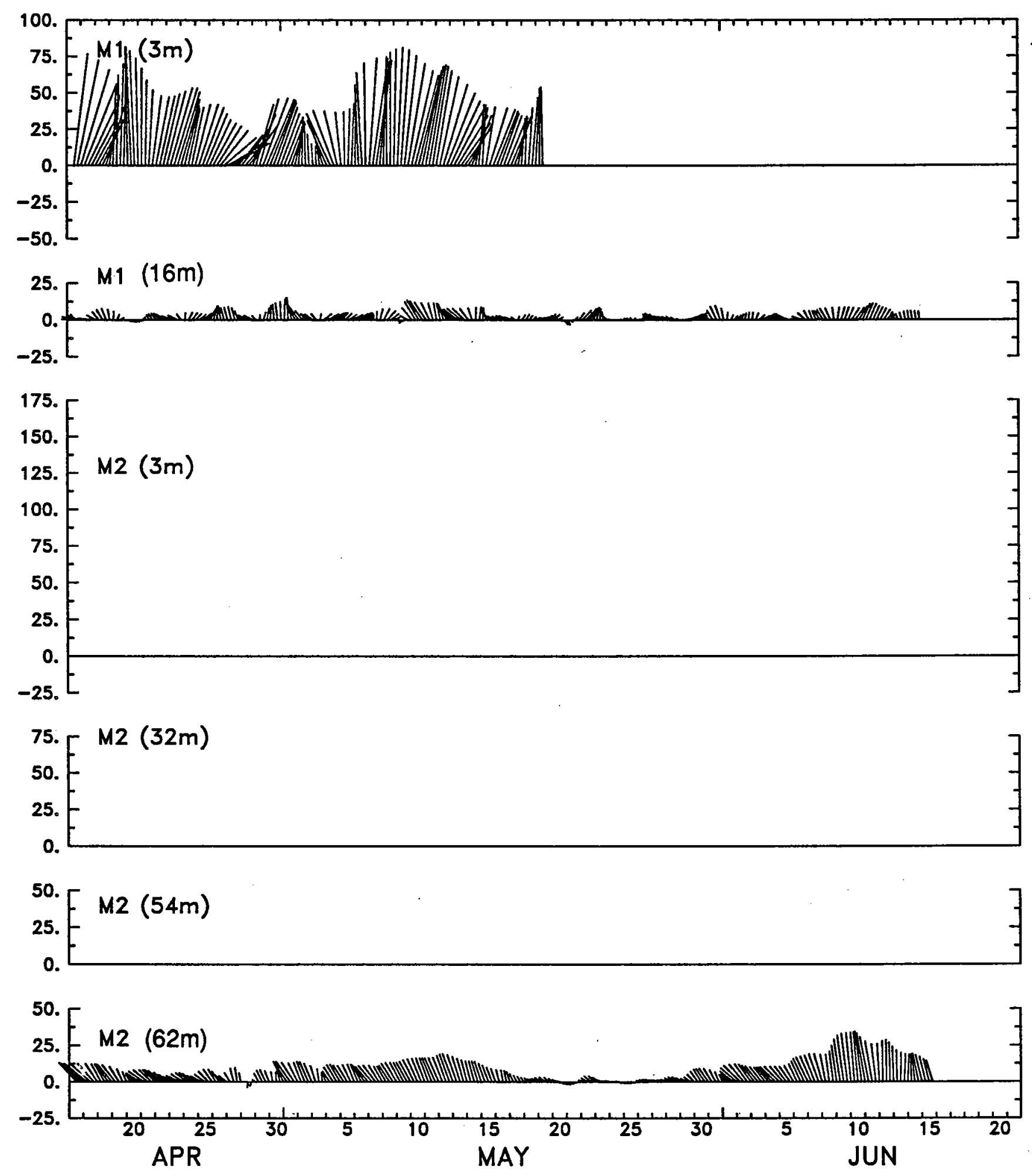
PL64 Low-Pass Filtered Currents $(\mathrm{cm} / \mathrm{s})$ at $M 3$
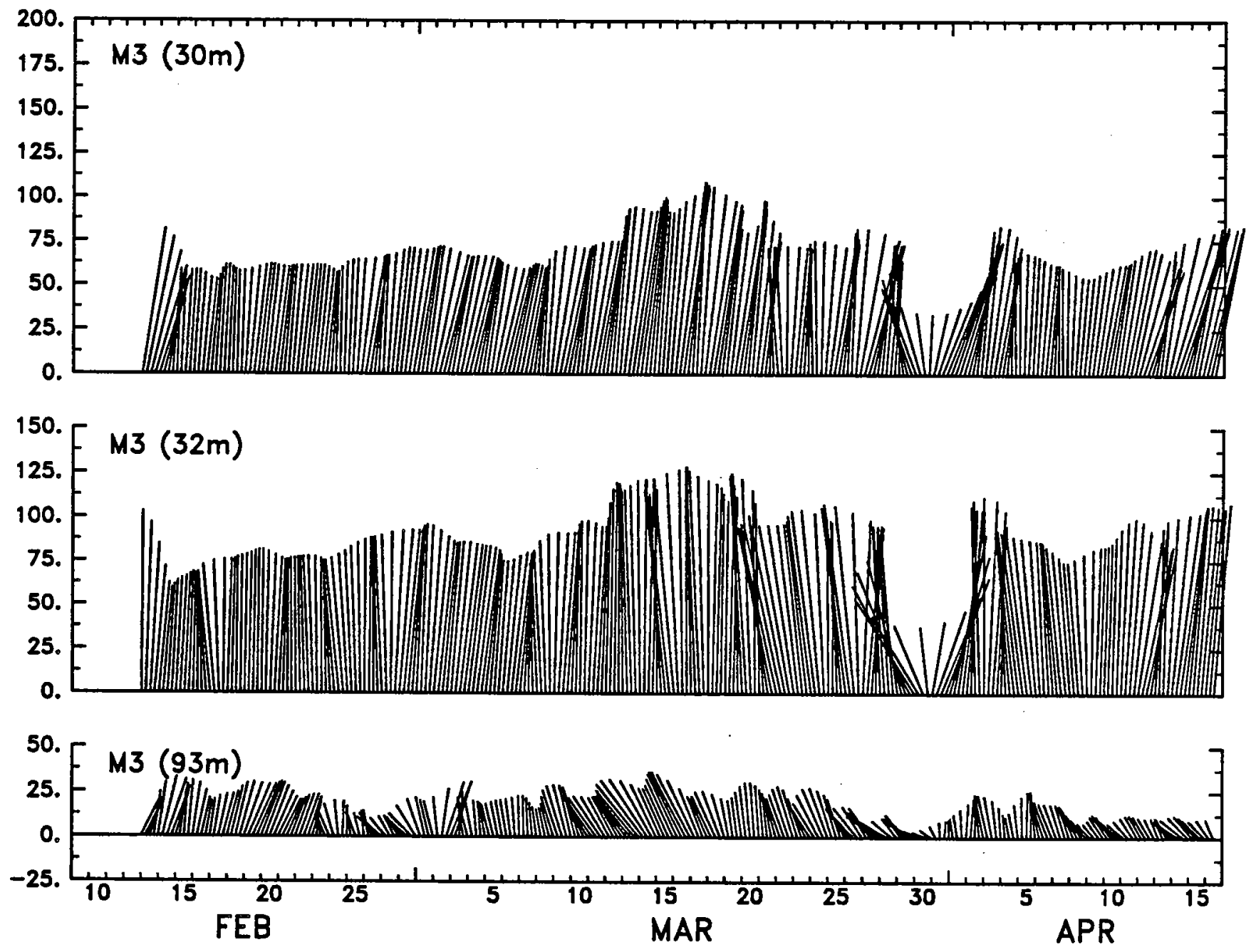
PL64 Low-Pass Filtered Currents $(\mathrm{cm} / \mathrm{s})$ at M3
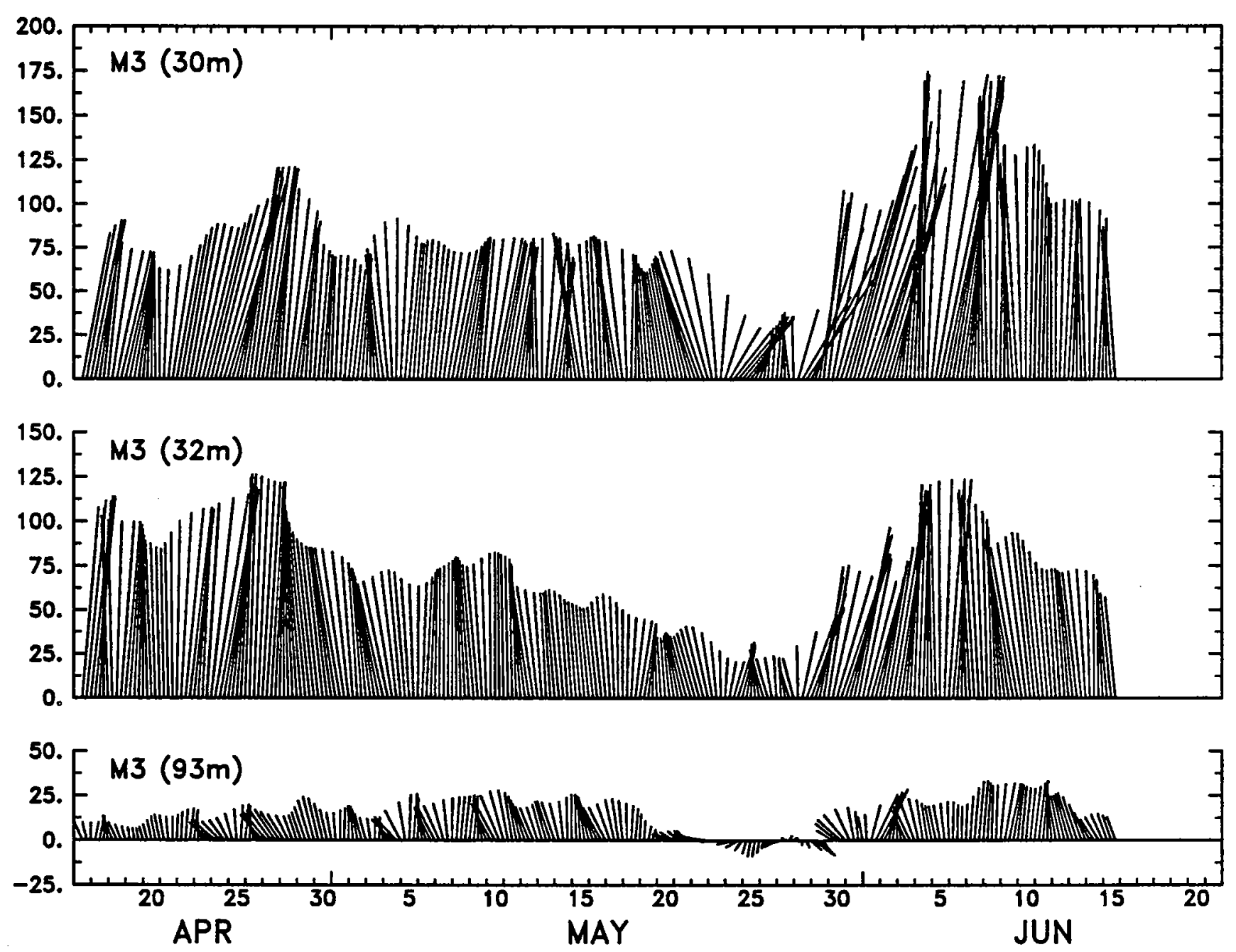
PL64 Low-Pass Filtered Cross-Shelf Component $(\mathrm{cm} / \mathrm{s})$ at $M 1$ and $M 2$

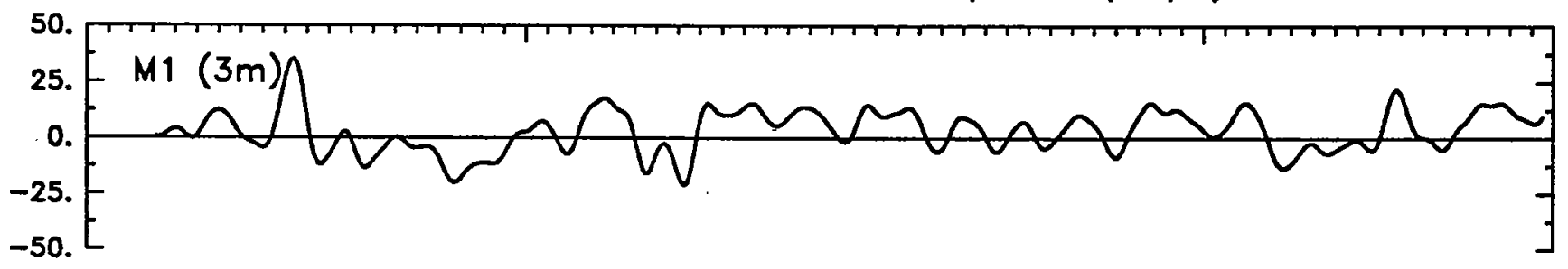

25. ${ }^{\mathrm{M1}(16 \mathrm{~m})}$

25. $E$ (3)

25.
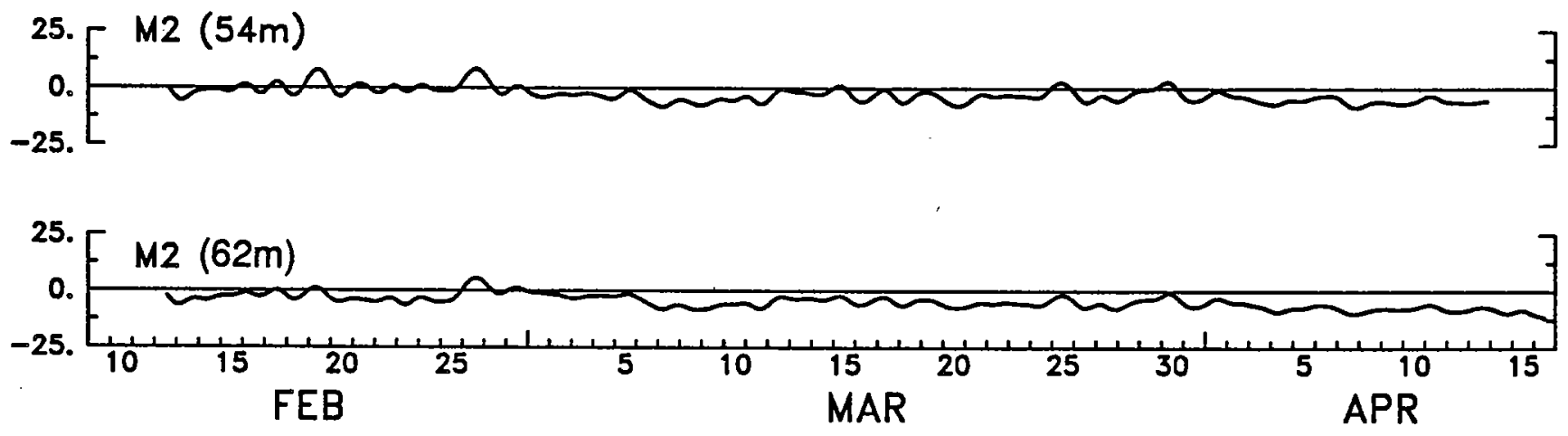
PL64 Low-Pass Filtered Cross-Shelf Component $(\mathrm{cm} / \mathrm{s})$ at $M 1$ and $M 2$
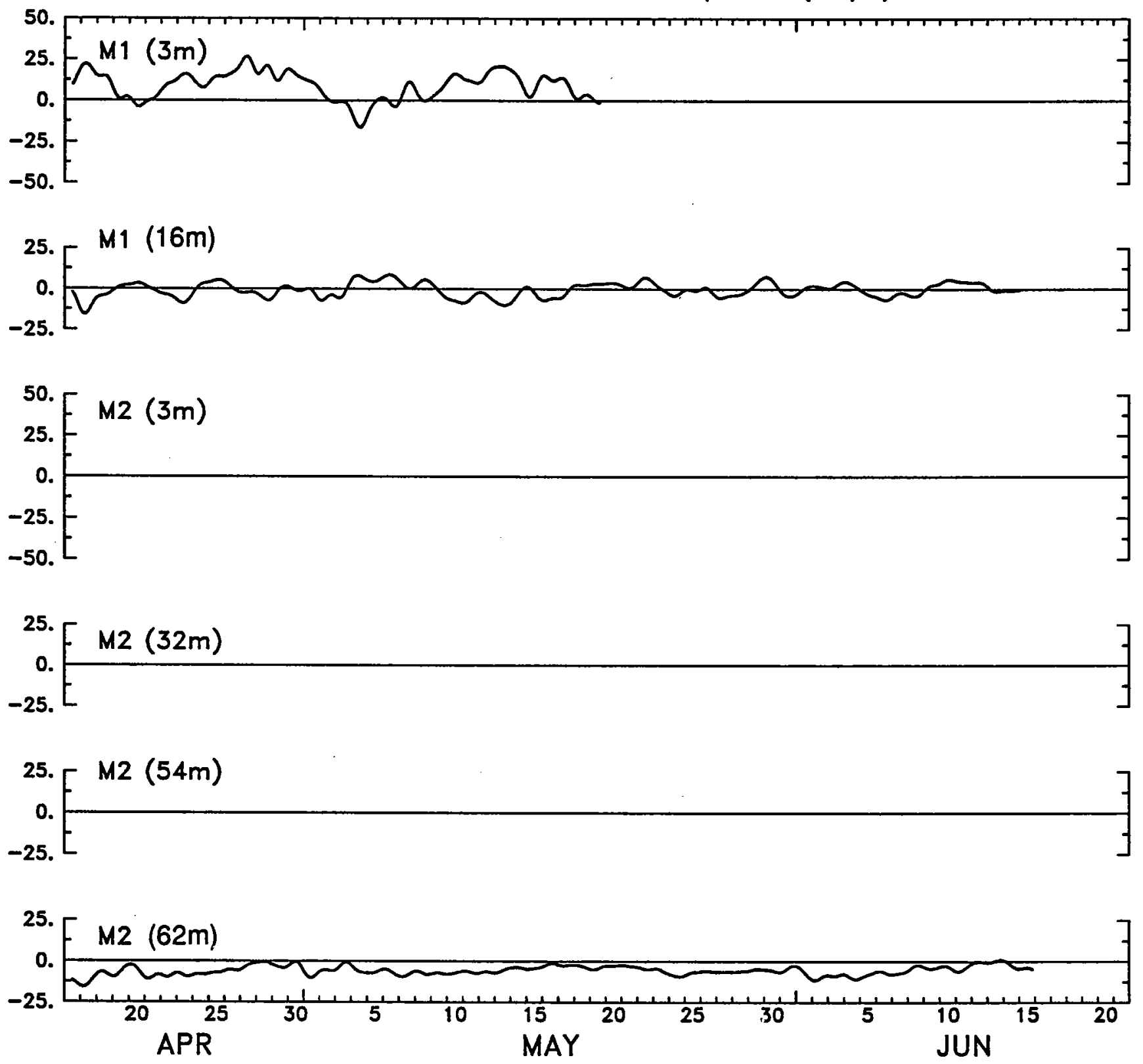
PL64 Low-Pass Filtered Cross-Shelf Component $(\mathrm{cm} / \mathrm{s})$ at M3
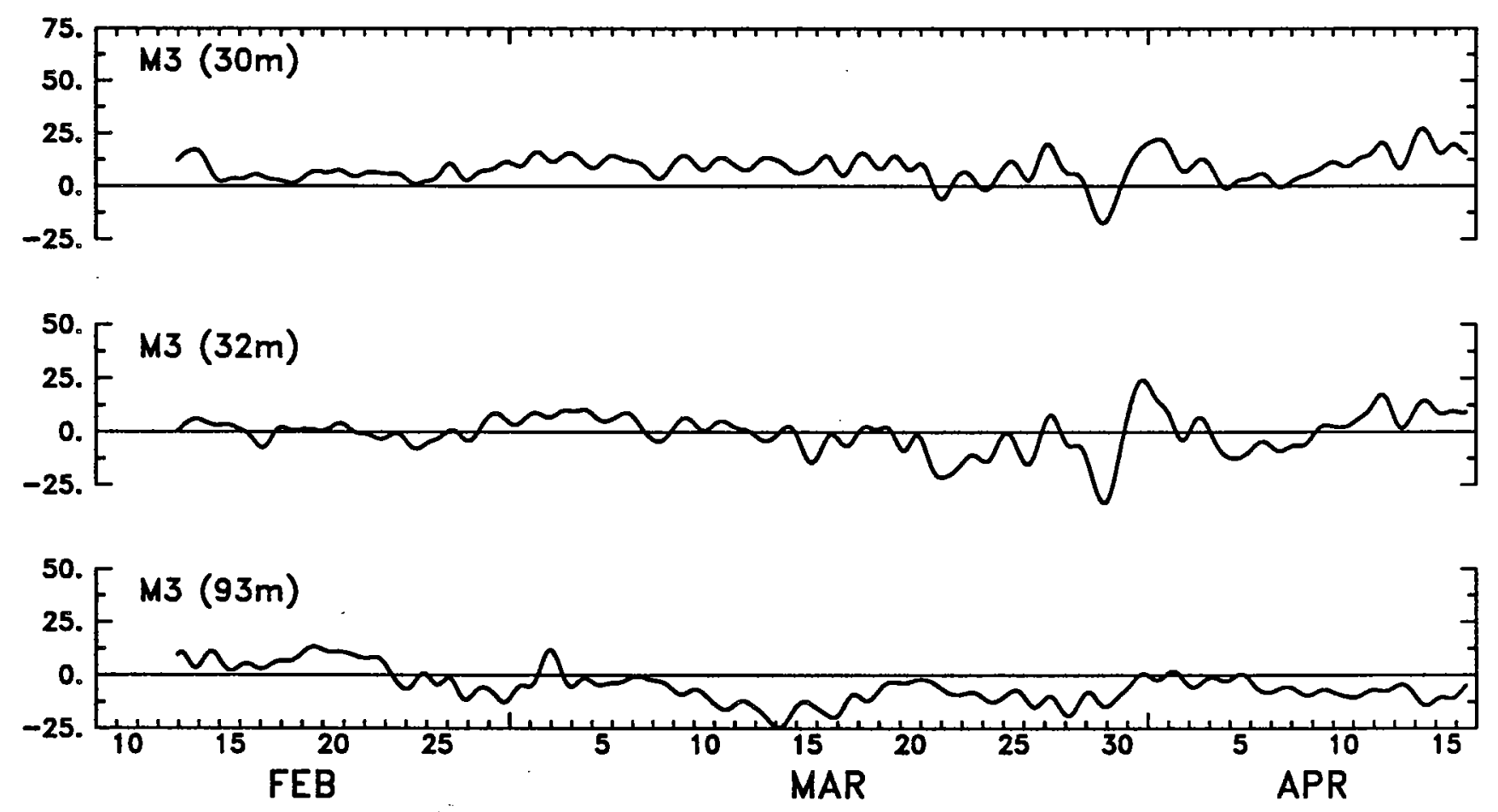
PL64 Low-Pass Filtered Cross-Shelf Component $(\mathrm{cm} / \mathrm{s})$ at M3
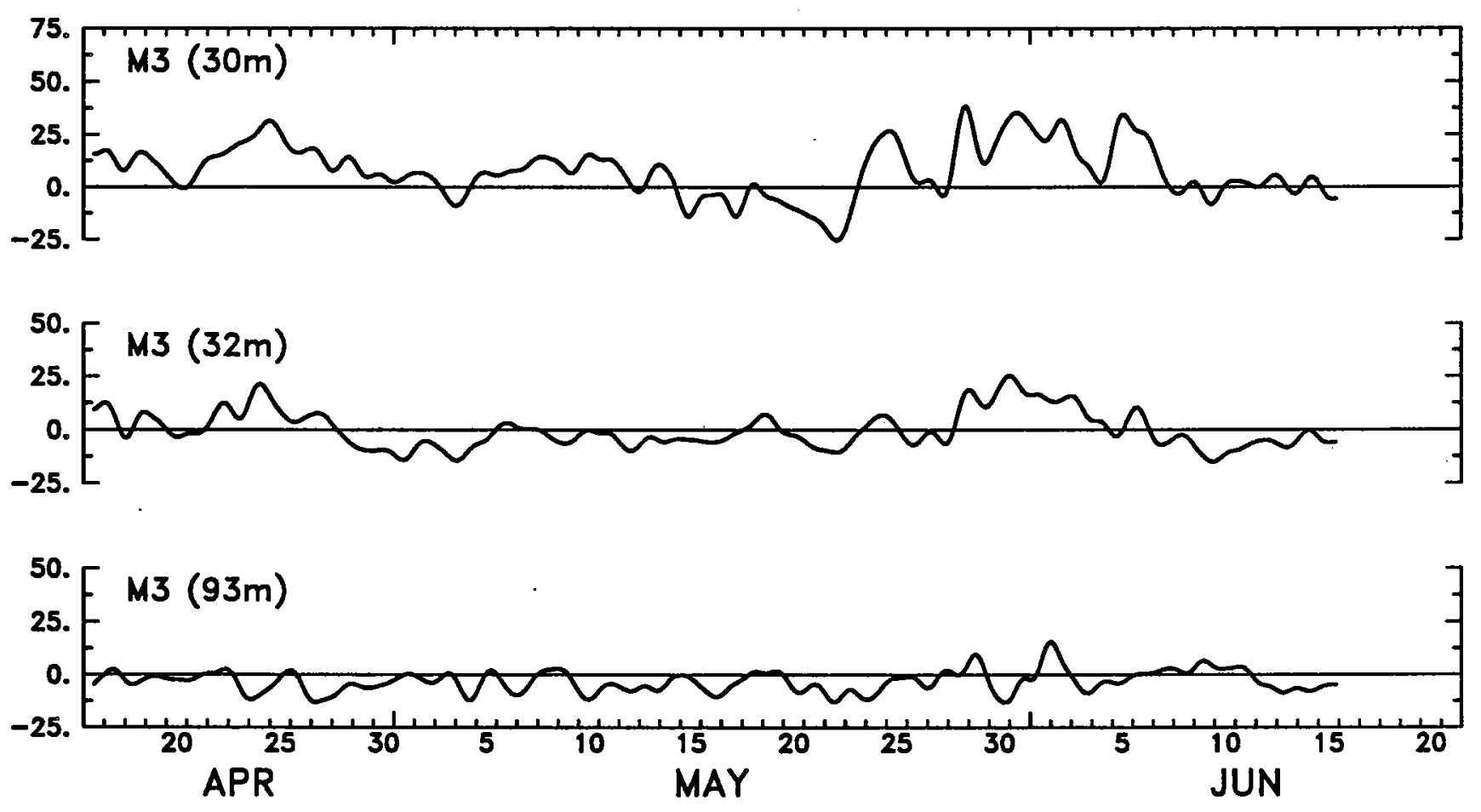
PL64 Low-Pass Filtered Alongshelf Component $(\mathrm{cm} / \mathrm{s})$ at $M 1$ and $M 2$
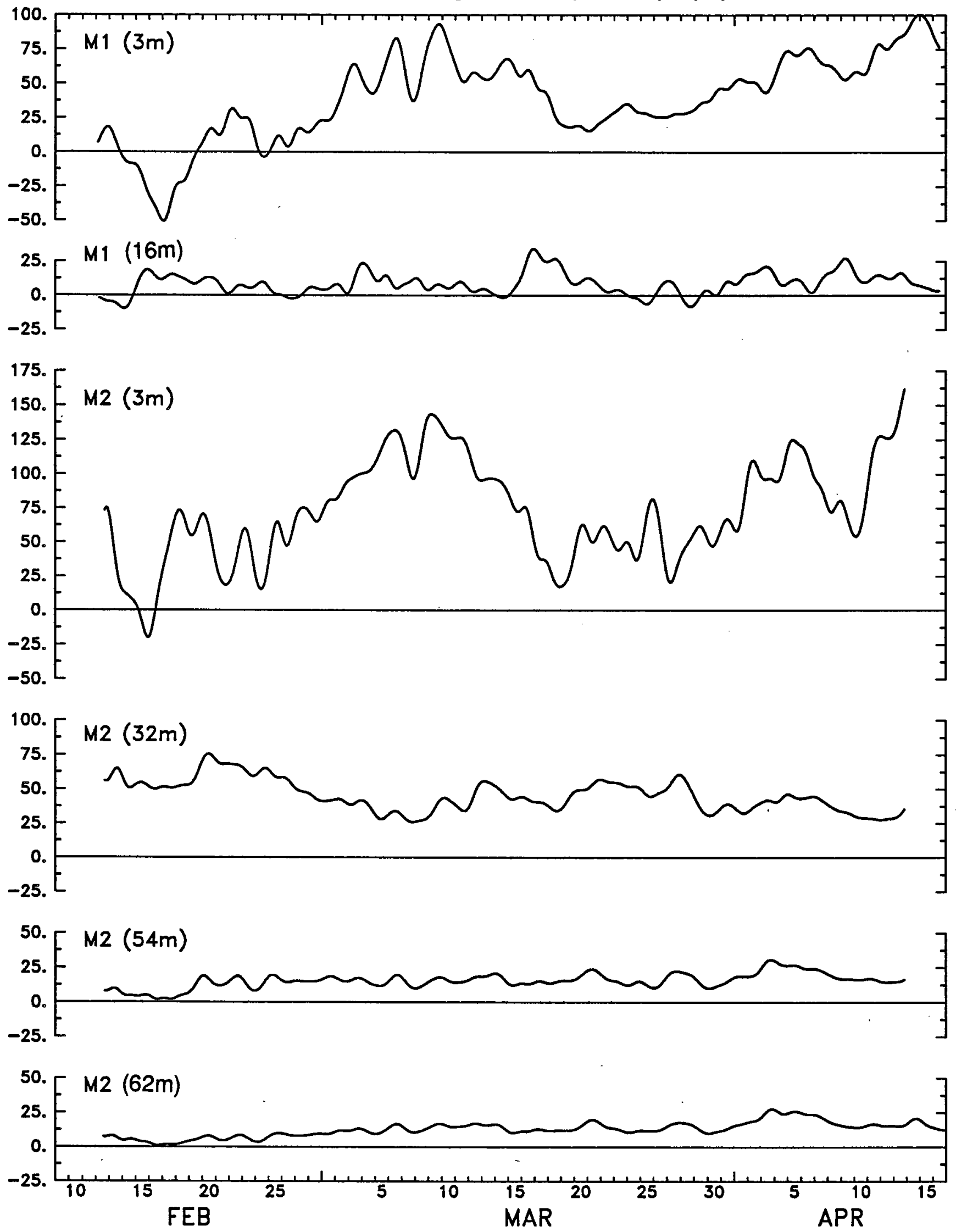
PL64 Low-Pass Filtered Alongshelf Component $(\mathrm{cm} / \mathrm{s})$ at M1 and M2
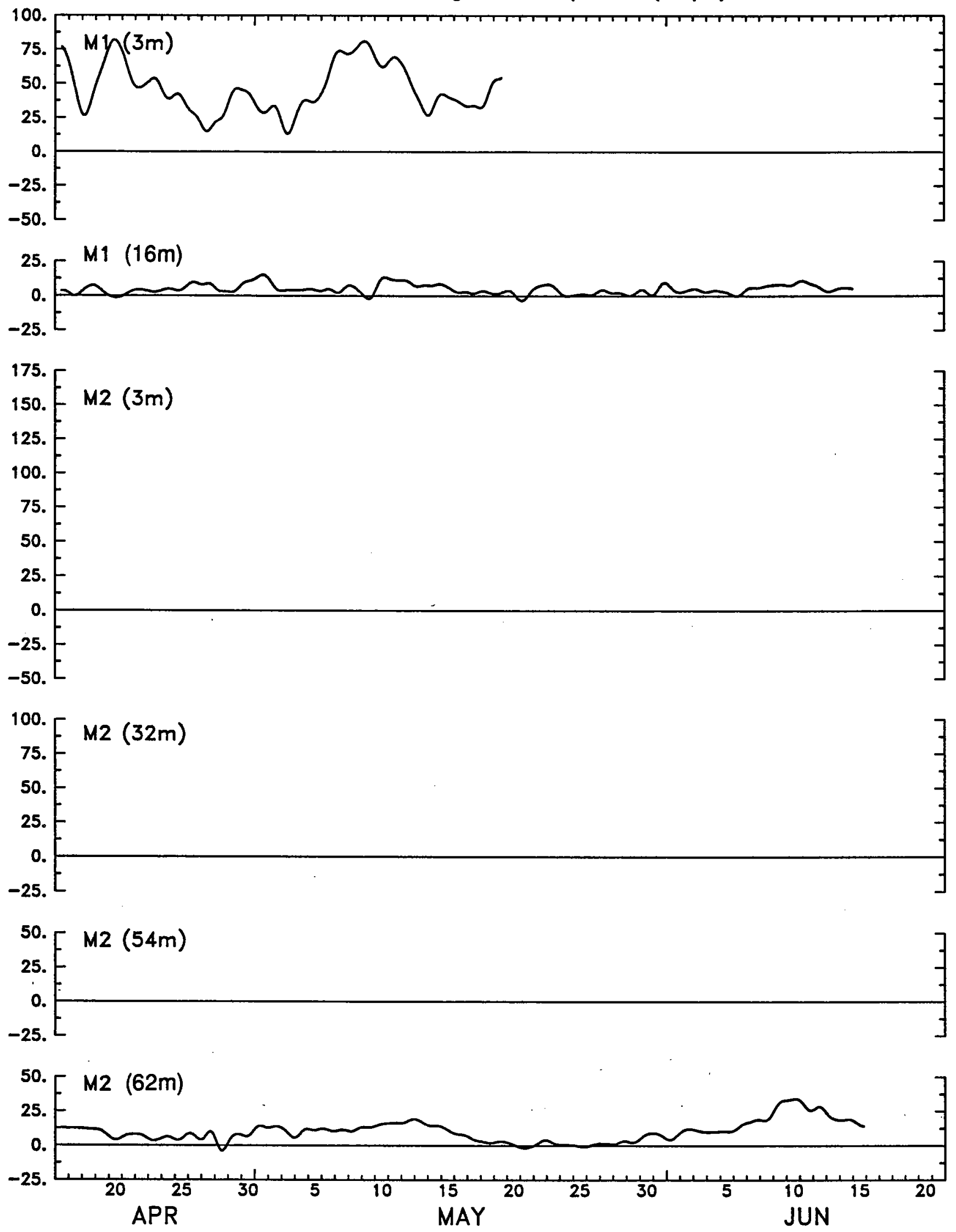
PL64 Low-Pass Filtered Alongshelf Component $(\mathrm{cm} / \mathrm{s})$ at $M 3$
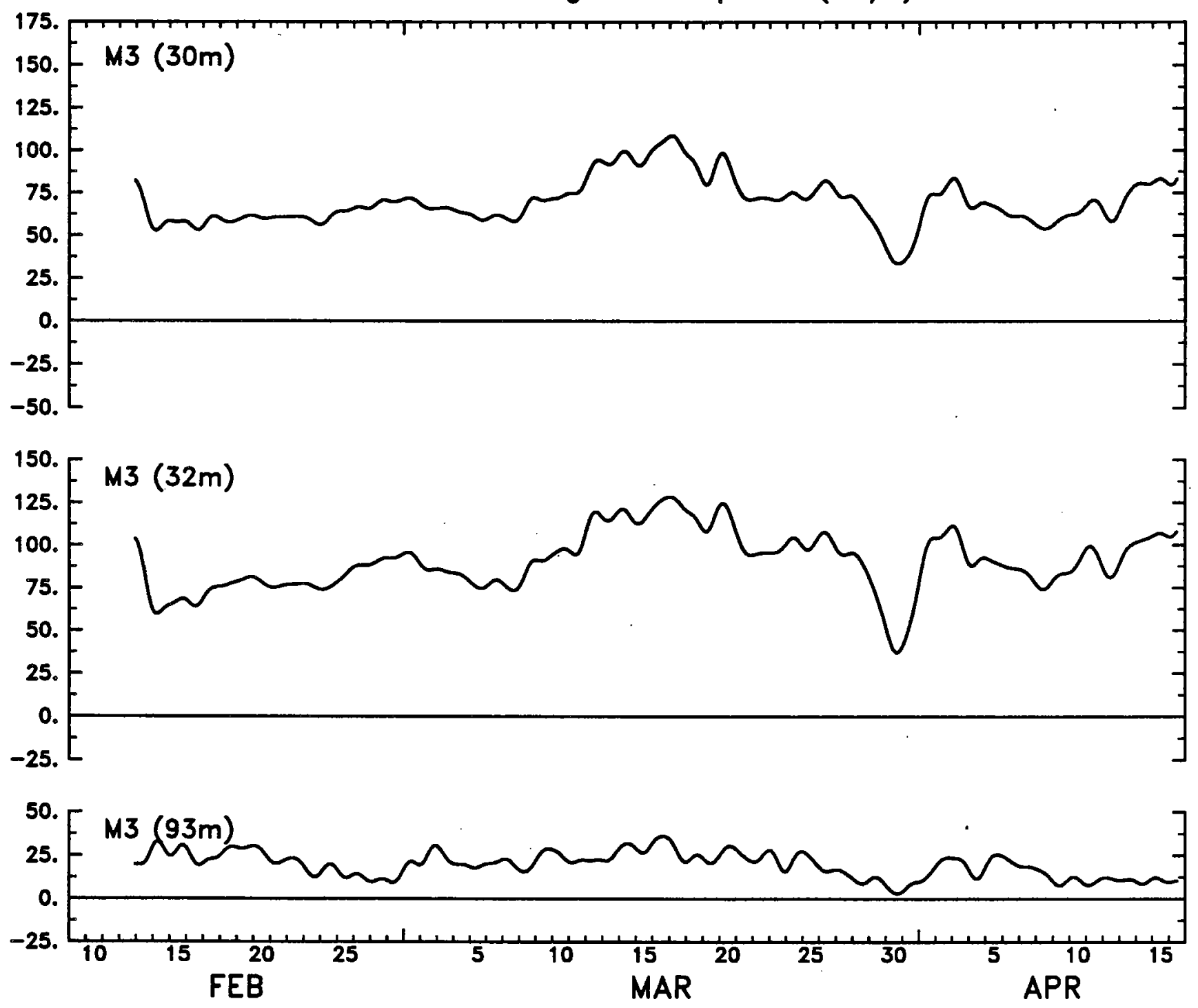
PL64 Low-Pass Filtered Alongshelf Component $(\mathrm{cm} / \mathrm{s})$ at $M 3$
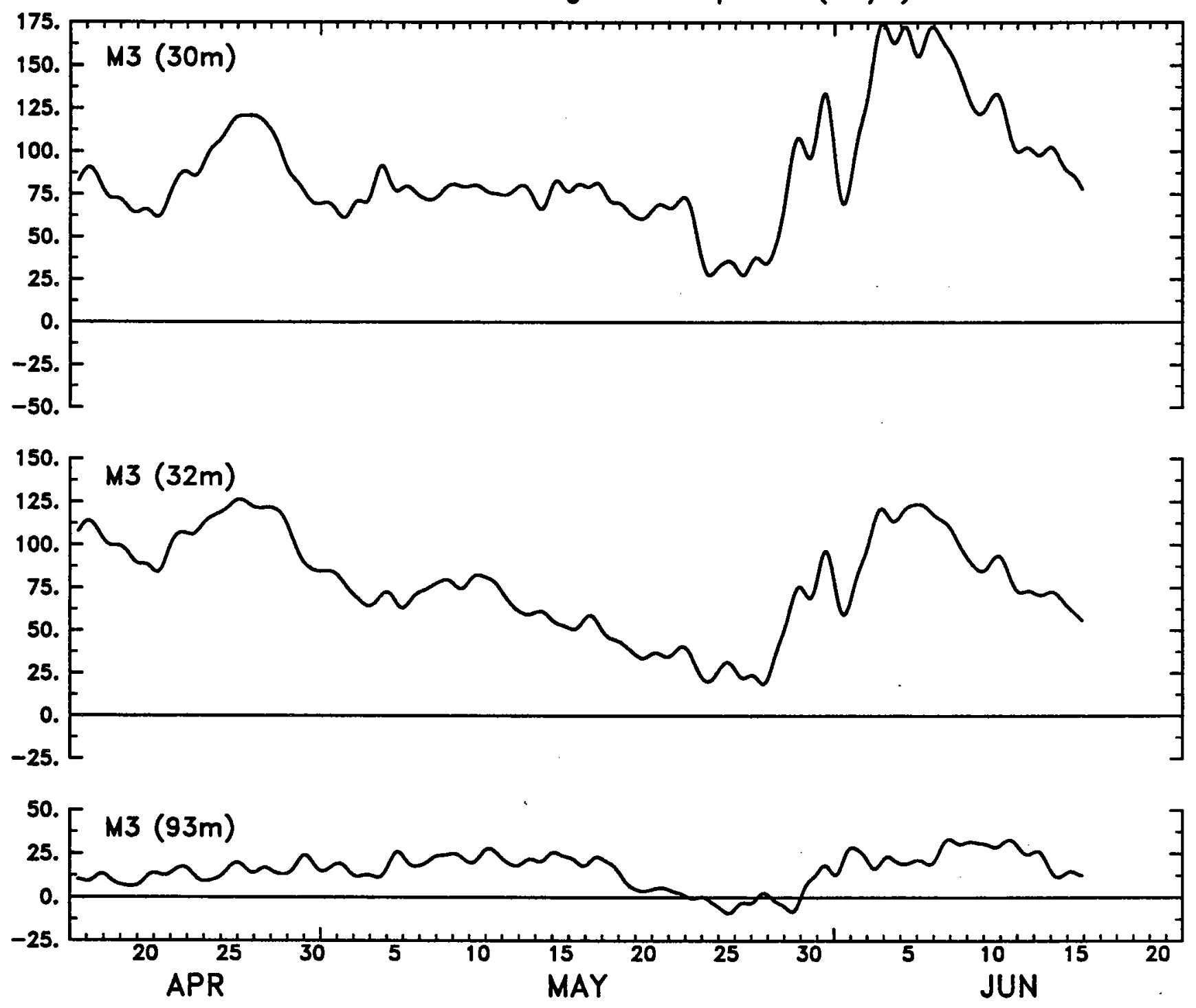
Hourly-Averaged Cross-Shelf Component $(\mathrm{cm} / \mathrm{s})$ at $M 1$ and $M 2$

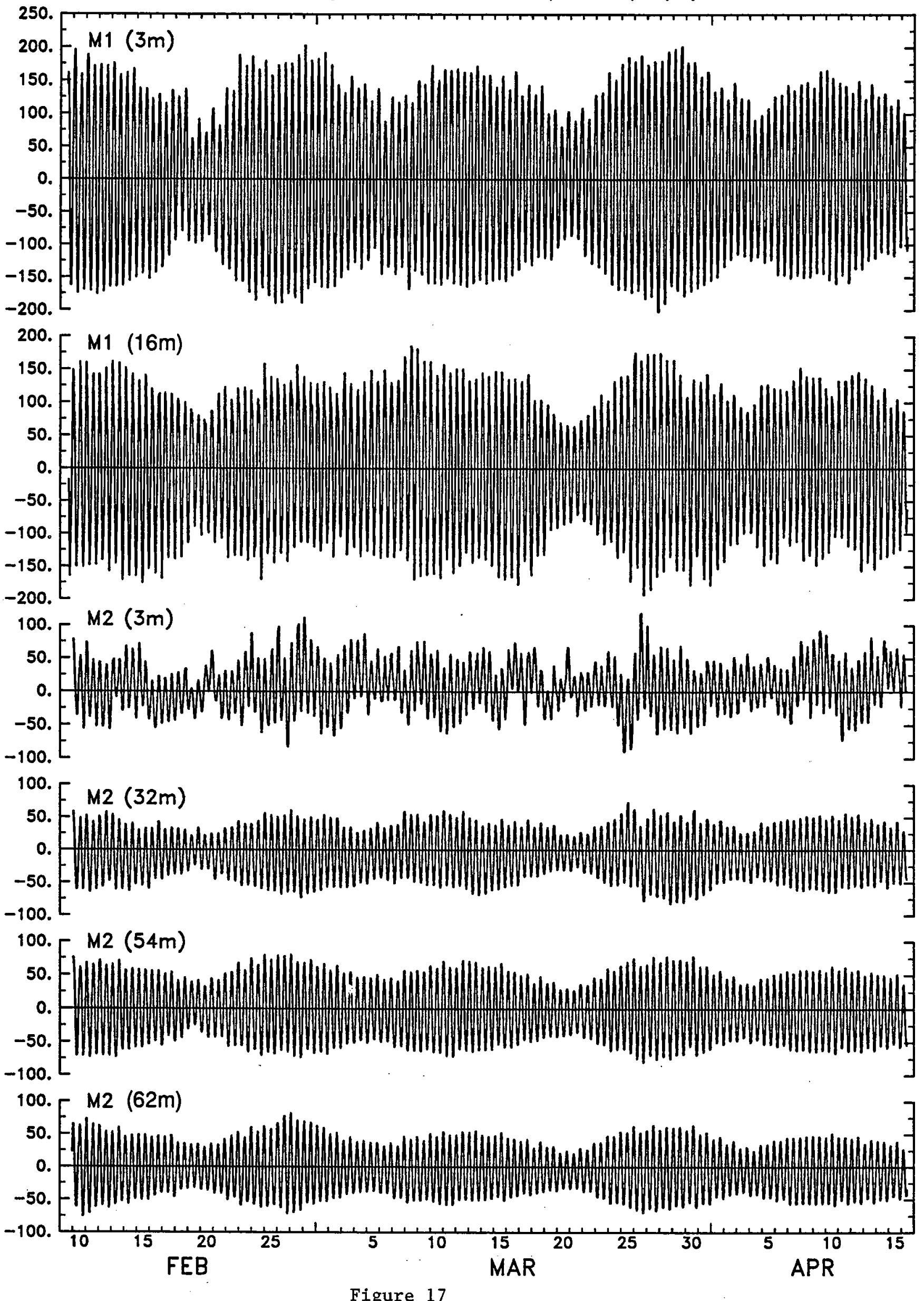


Hourly-Averaged Cross-Shelf Component $(\mathrm{cm} / \mathrm{s})$ at $M 1$ and $M 2$

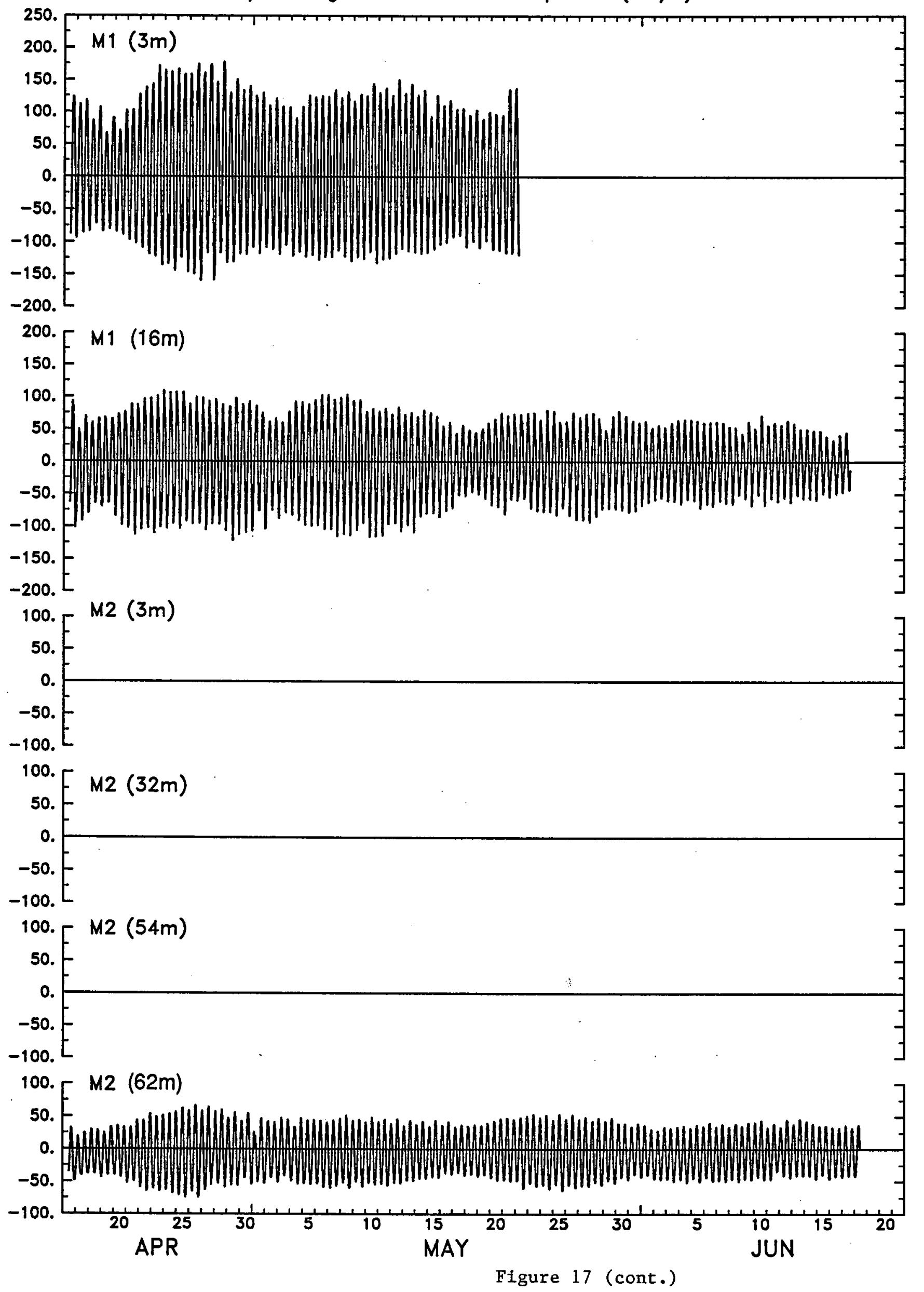


Hourly-Averaged Cross-Shelf Component $(\mathrm{cm} / \mathrm{s})$ at $M 3$

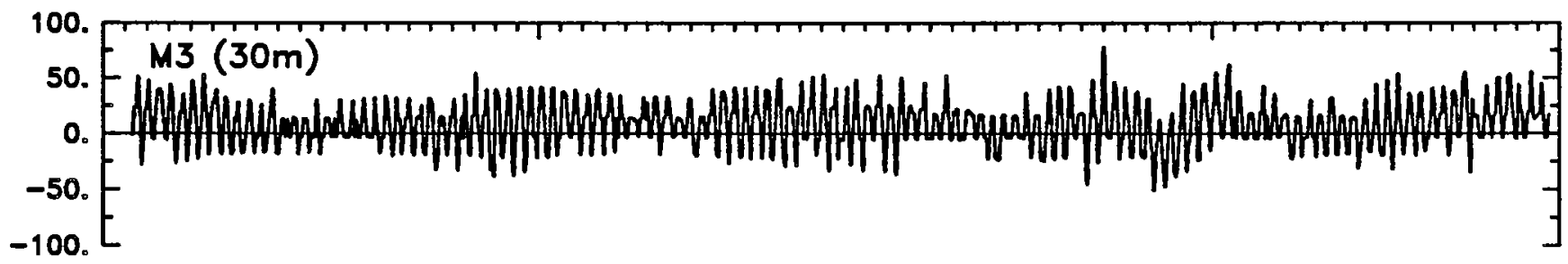

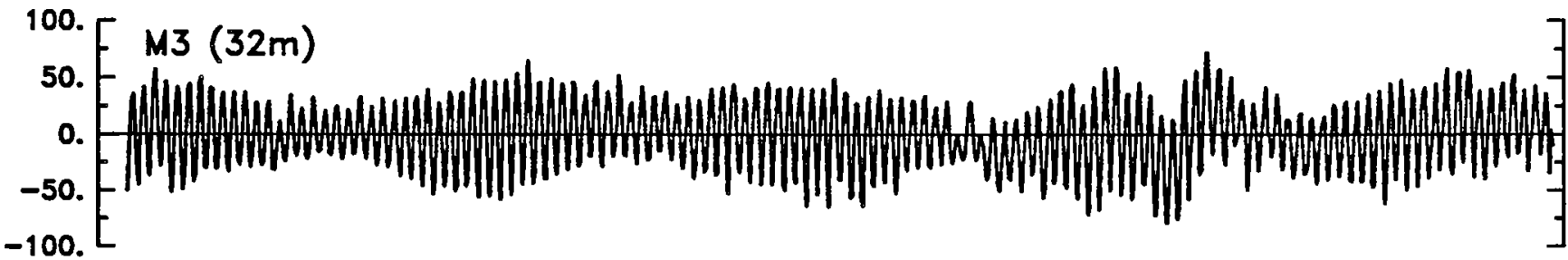

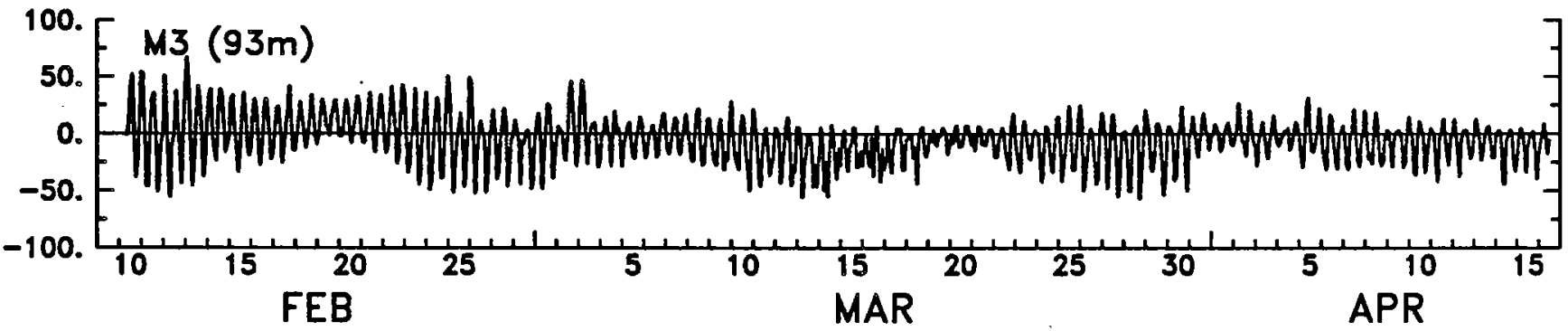


Hourly-Averaged Cross-Shelf Component $(\mathrm{cm} / \mathrm{s})$ at $M 3$

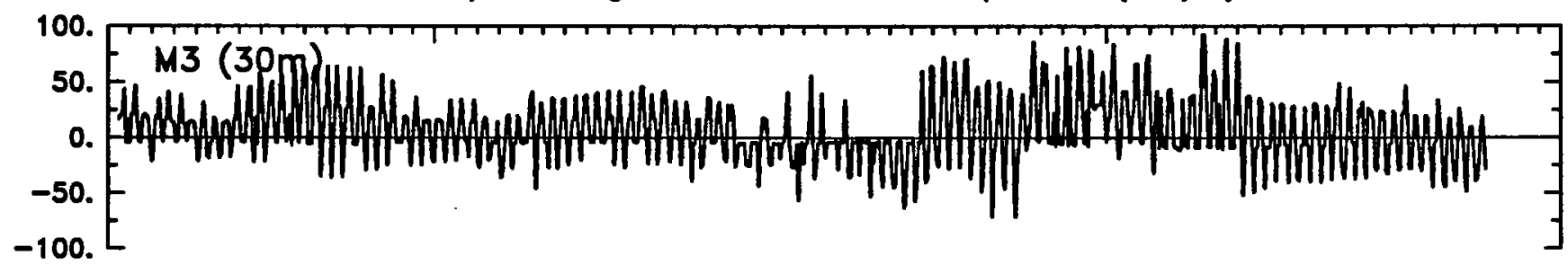

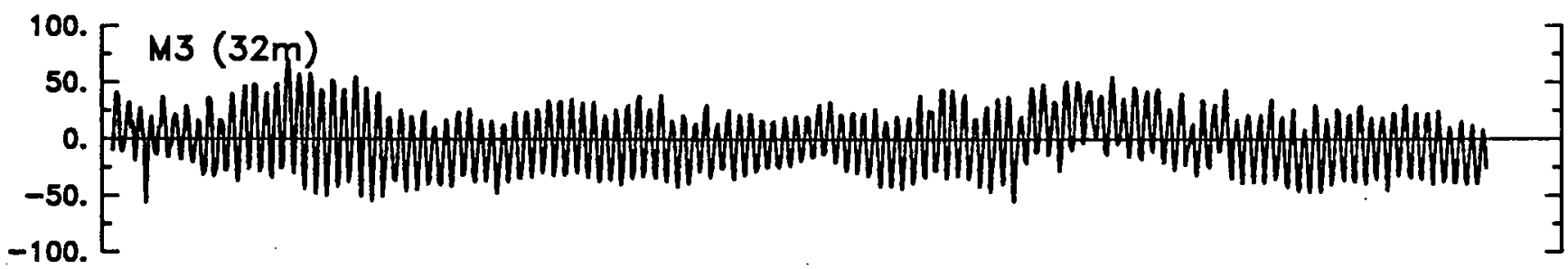

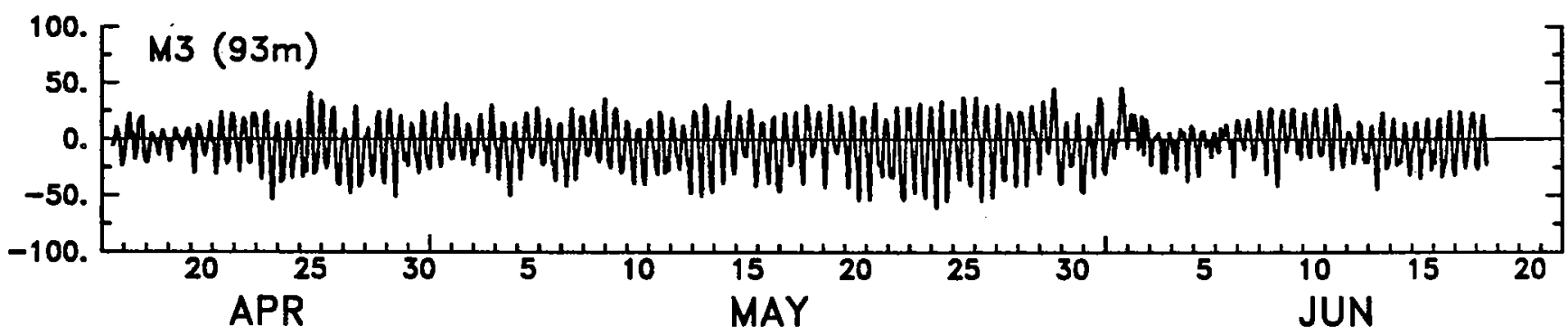


Hourly-Averaged Alongshelf Component $(\mathrm{cm} / \mathrm{s})$ at $M 1$ and $M 2$

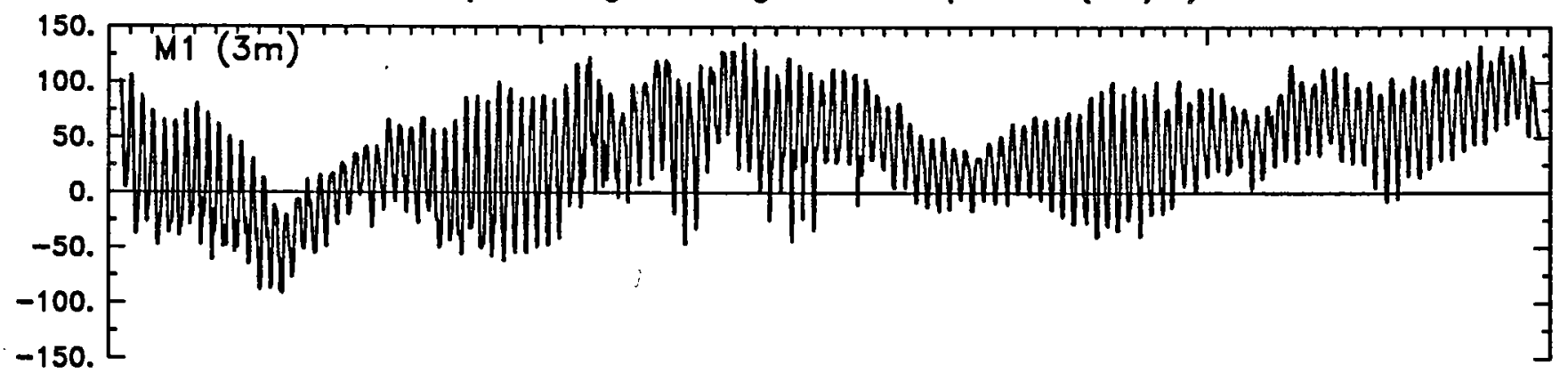

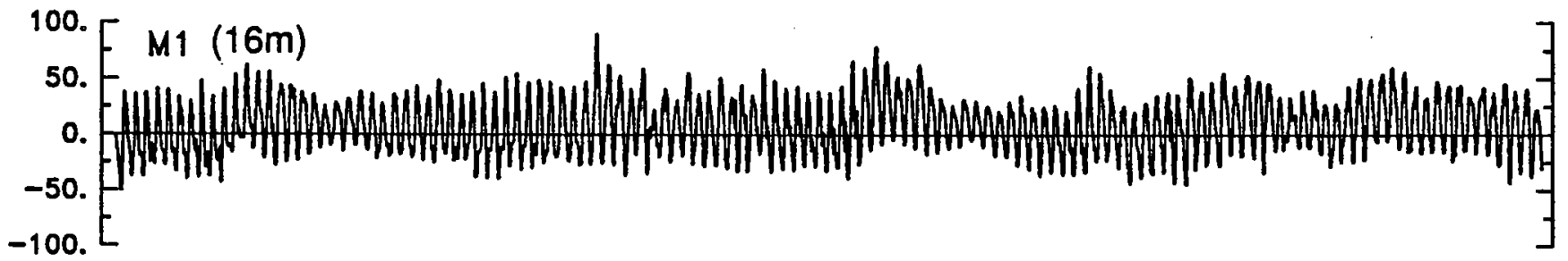

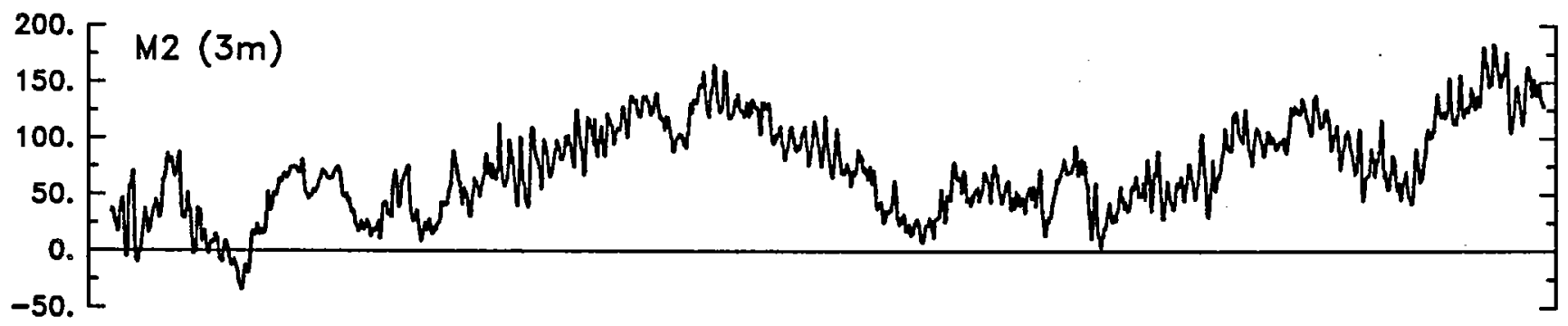

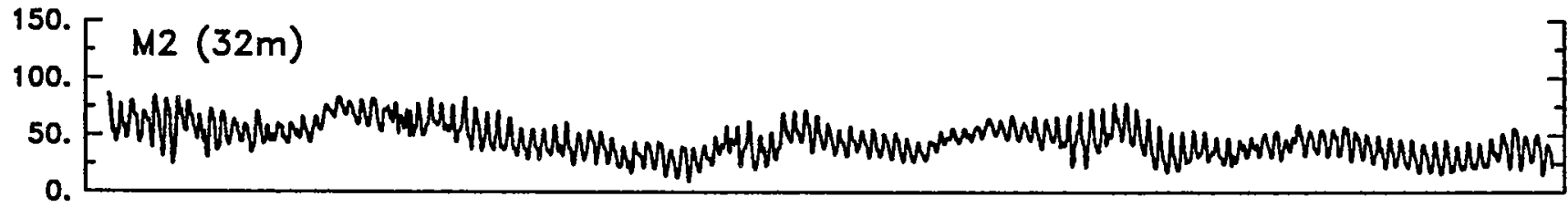

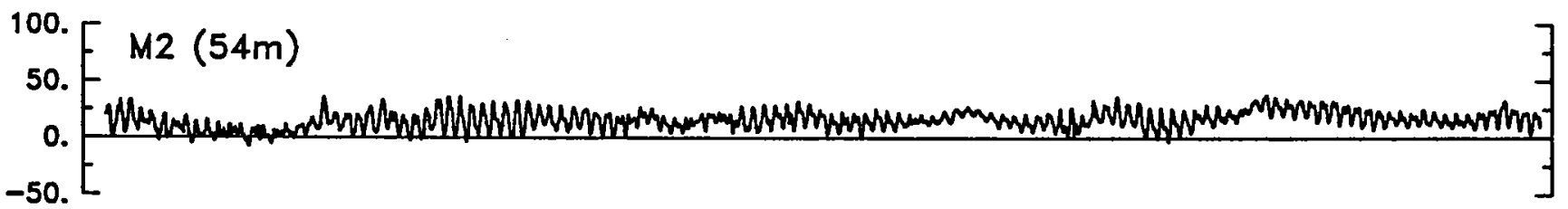

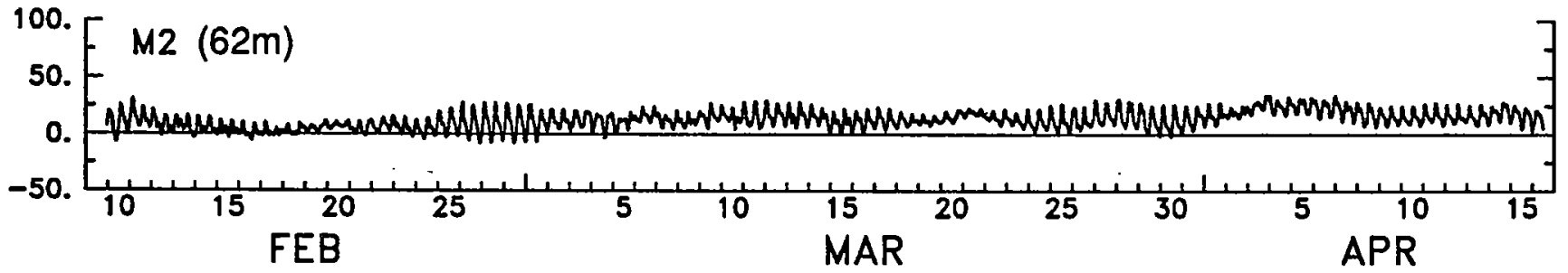


Hourly-Averaged Alongshelf Component $(\mathrm{cm} / \mathrm{s})$ at $M 1$ and $M 2$
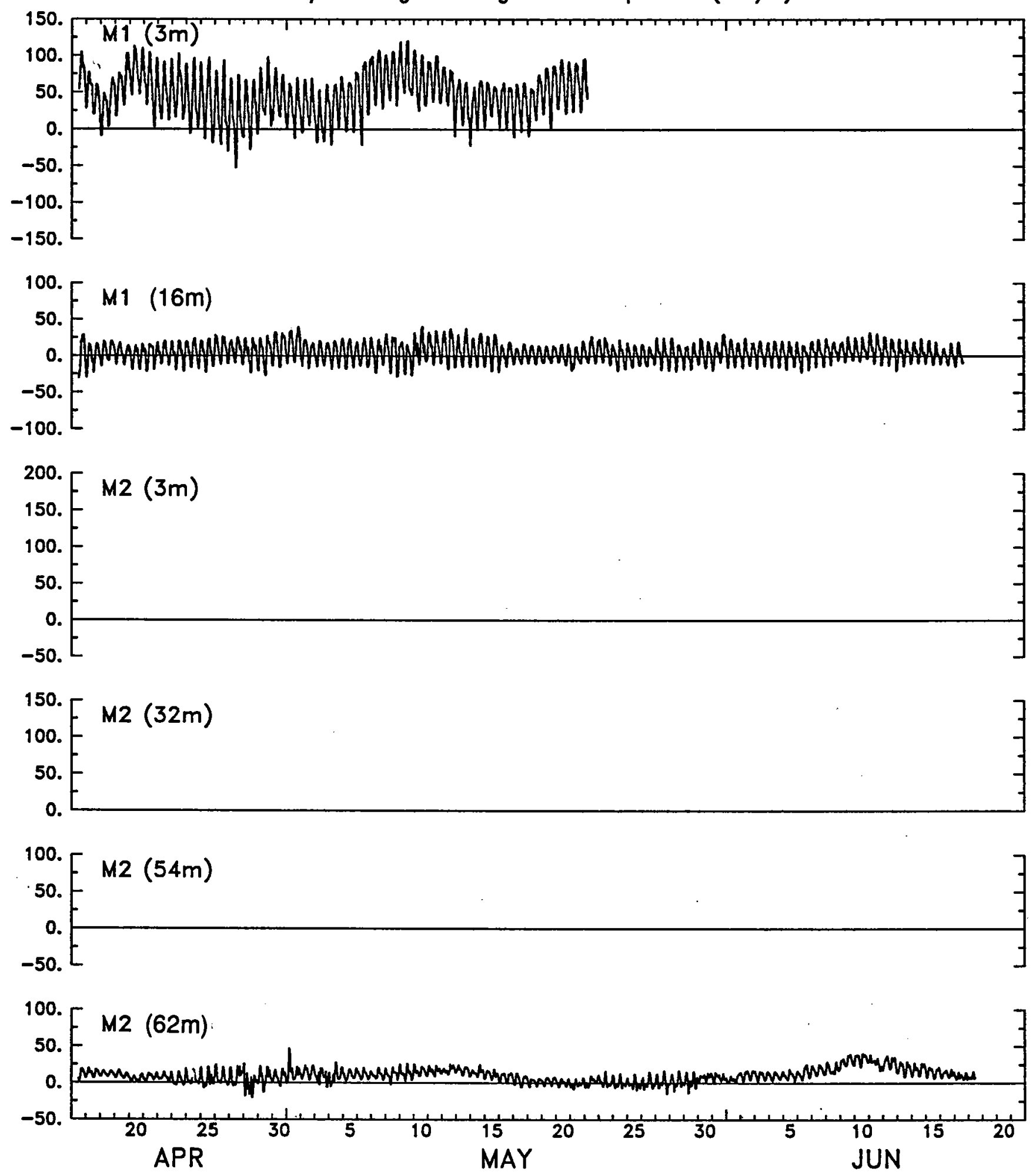
Hourly-Averaged Alongshelf Component $(\mathrm{cm} / \mathrm{s})$ at $M 3$
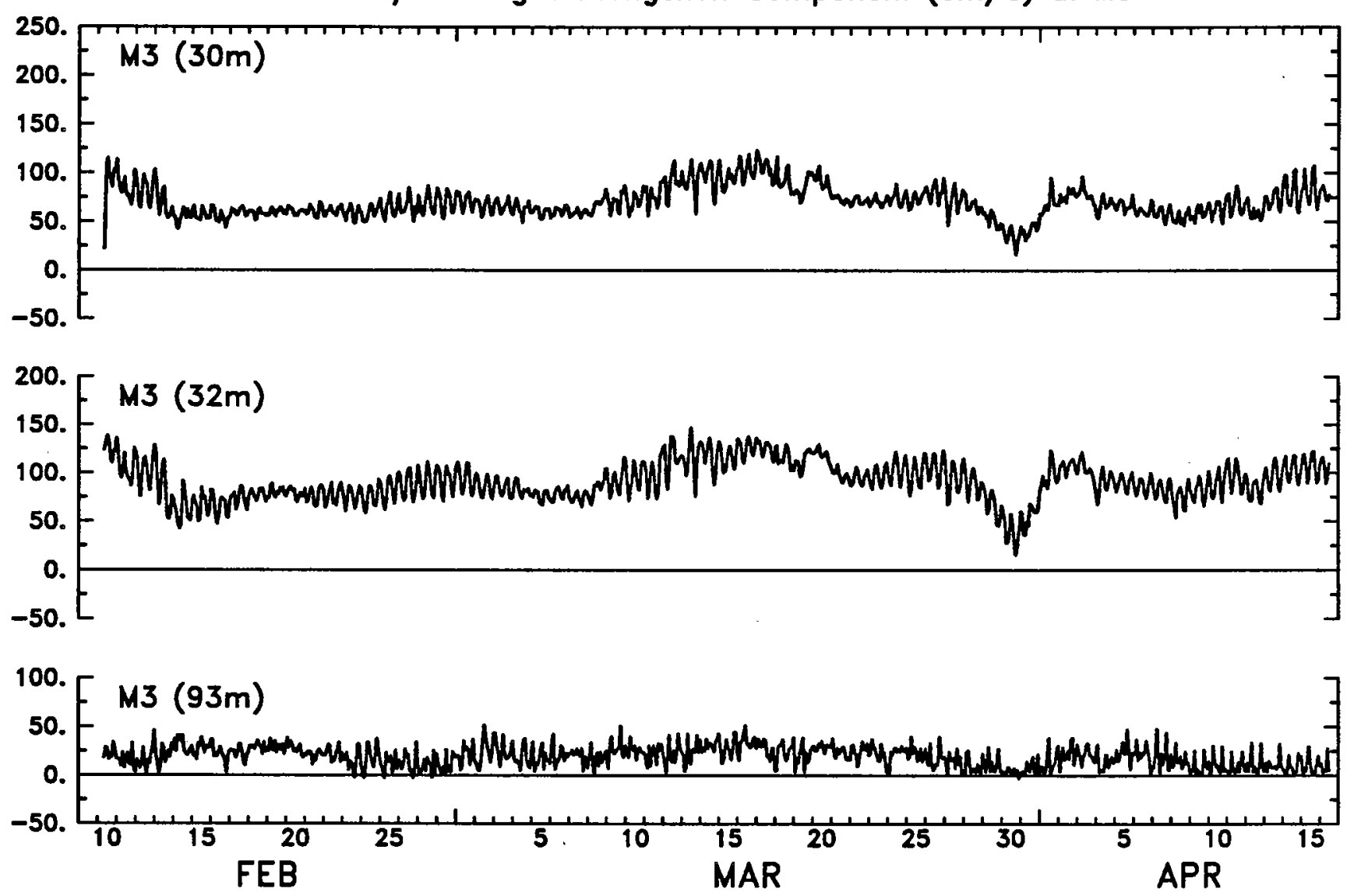
Hourly-Averaged Alongshelf Component $(\mathrm{cm} / \mathrm{s})$ at $M 3$
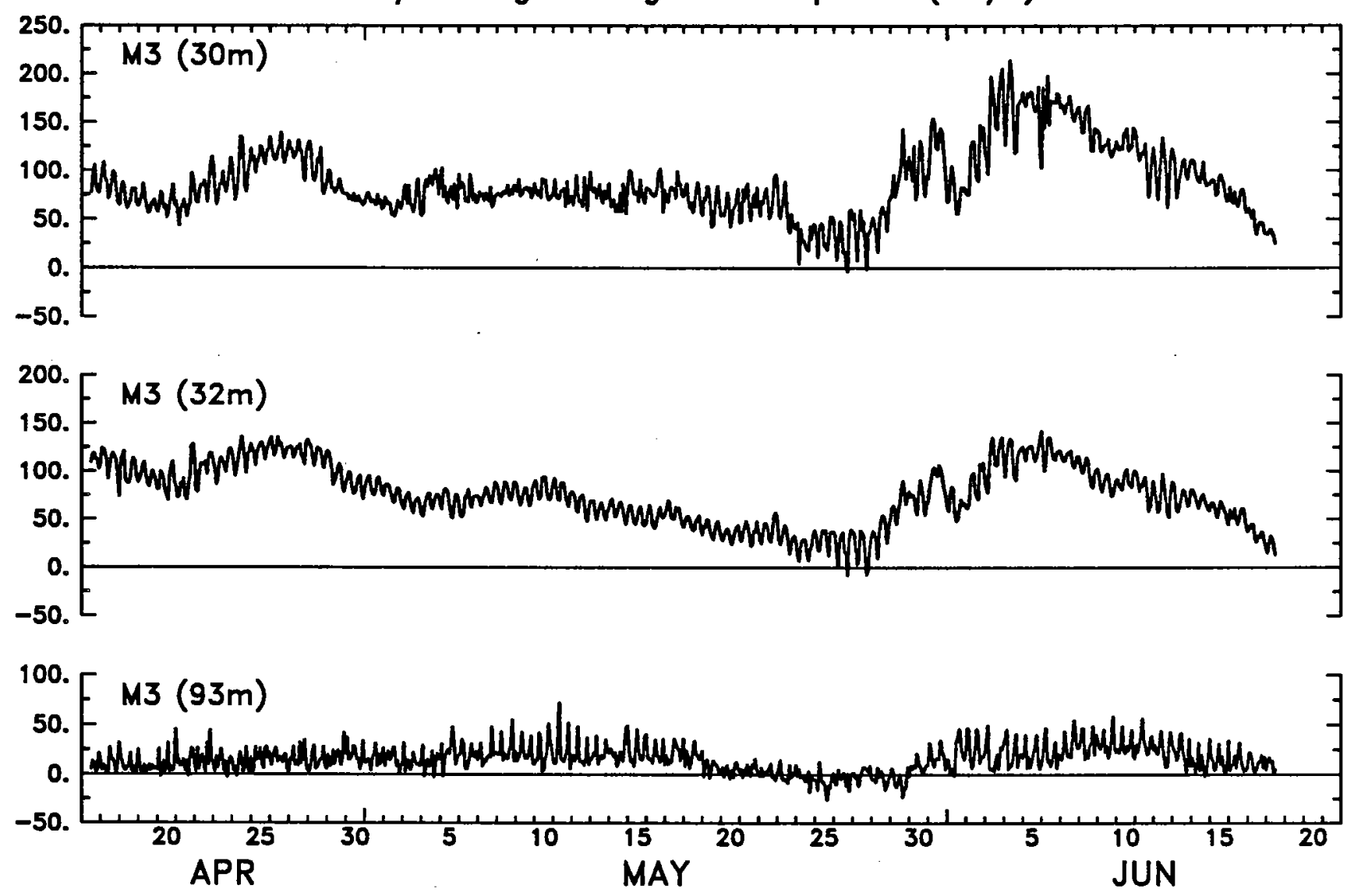
PL64 Low-Pass Filtered Water Temperature $\left({ }^{\circ} \mathrm{C}\right)$ at $\mathrm{M} 1$

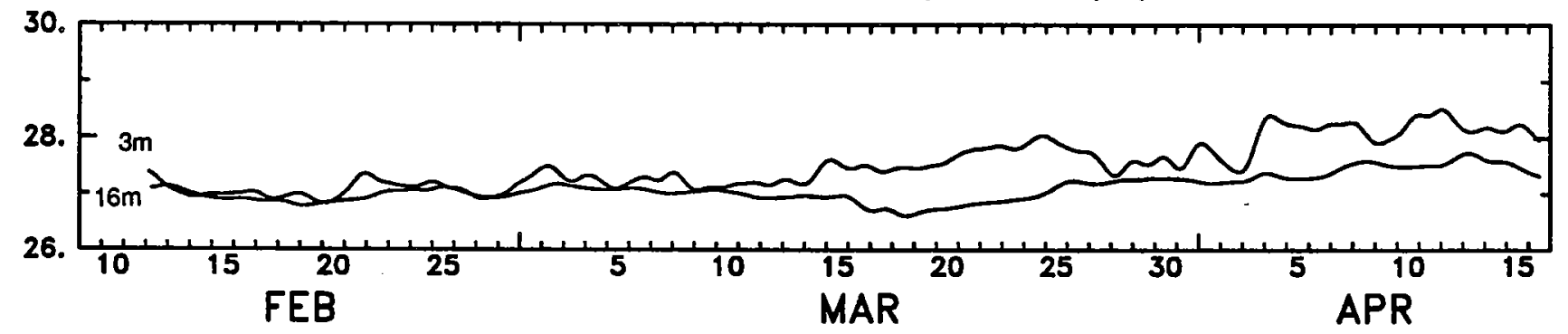

PL64 Low-Pass Filtered Water Temperature $\left({ }^{\circ} \mathrm{C}\right)$ at M2

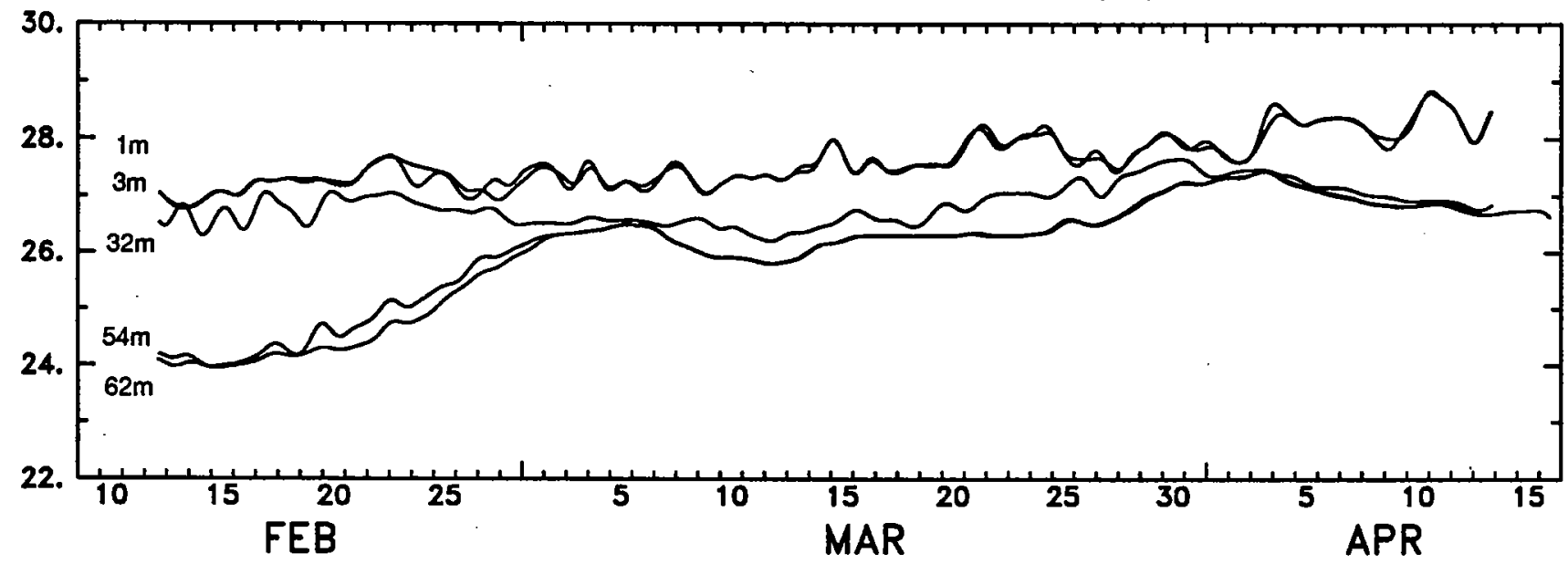

PL64 Low-Pass Filtered Water Temperature $\left({ }^{\circ} \mathrm{C}\right)$ at M3

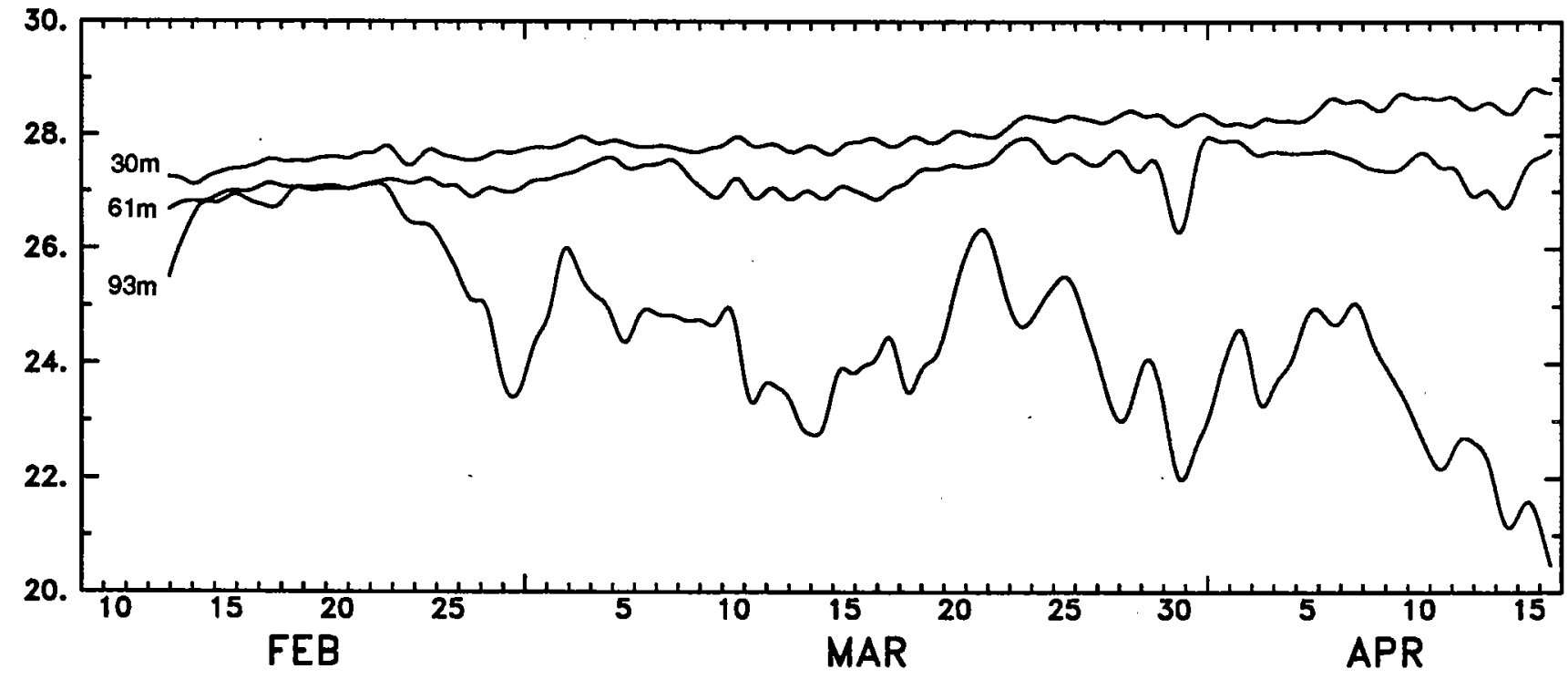


PL64 Low-Pass Filtered Water Temperature $\left({ }^{\circ} \mathrm{C}\right)$ at M1

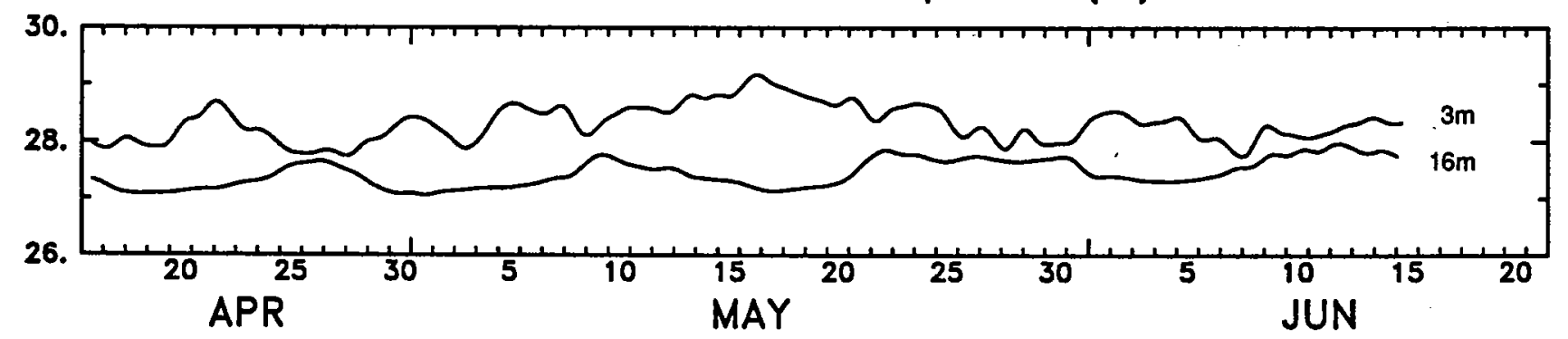

PL64 Low-Pass Filtered Water Temperature $\left({ }^{\circ} \mathrm{C}\right)$ at M2

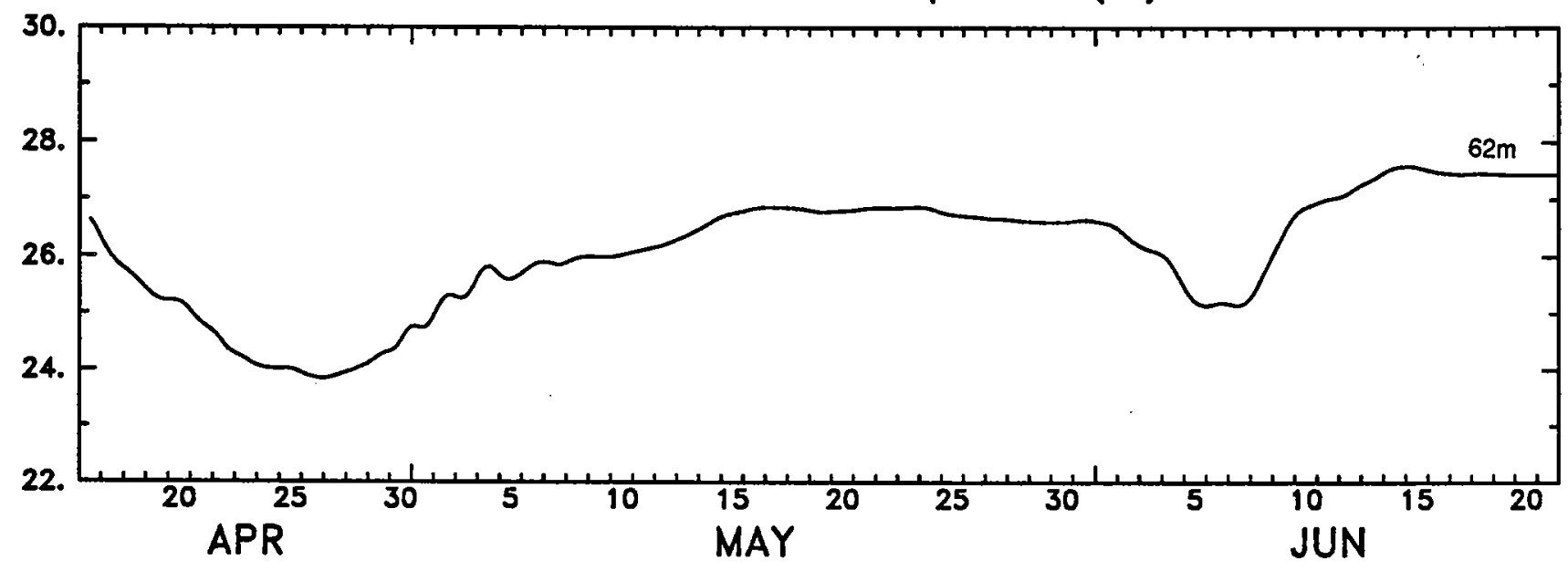

PL64 Low-Pass Filtered Water Temperature $\left({ }^{\circ} \mathrm{C}\right)$ at M3

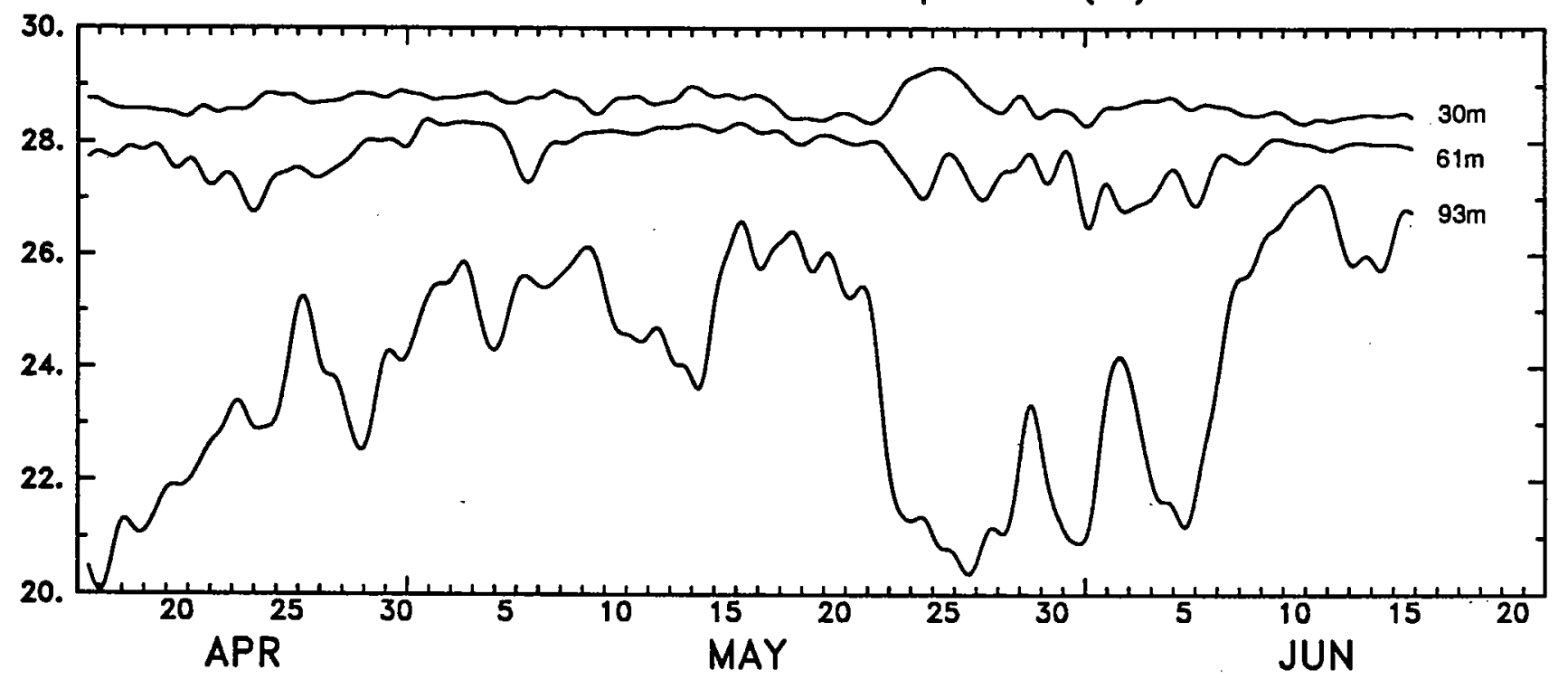


PL64 Low-Pass Filtered Salinity (psu) at M1

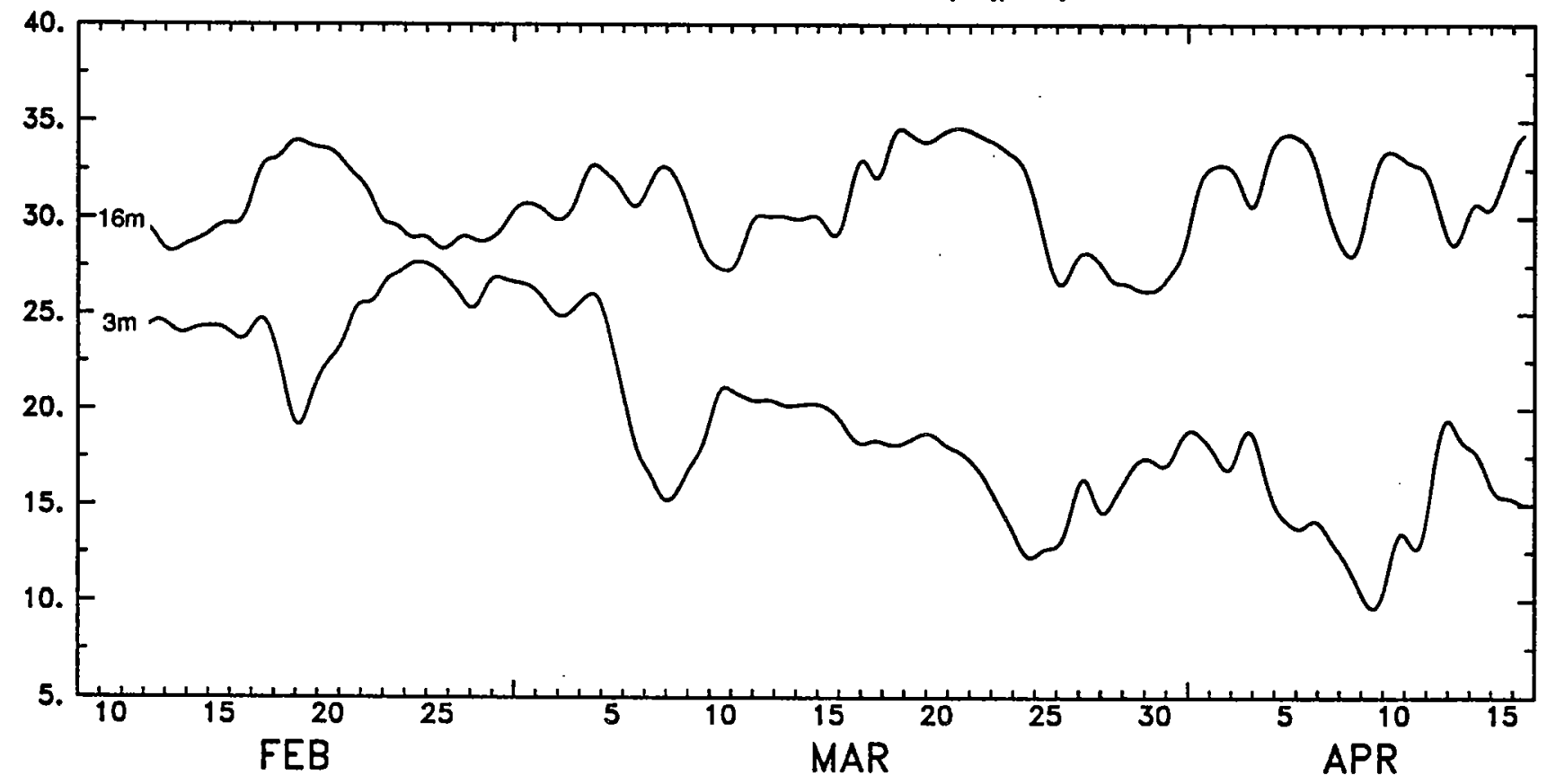

PL64 Low-Pass Filtered Salinity (psu) of M2

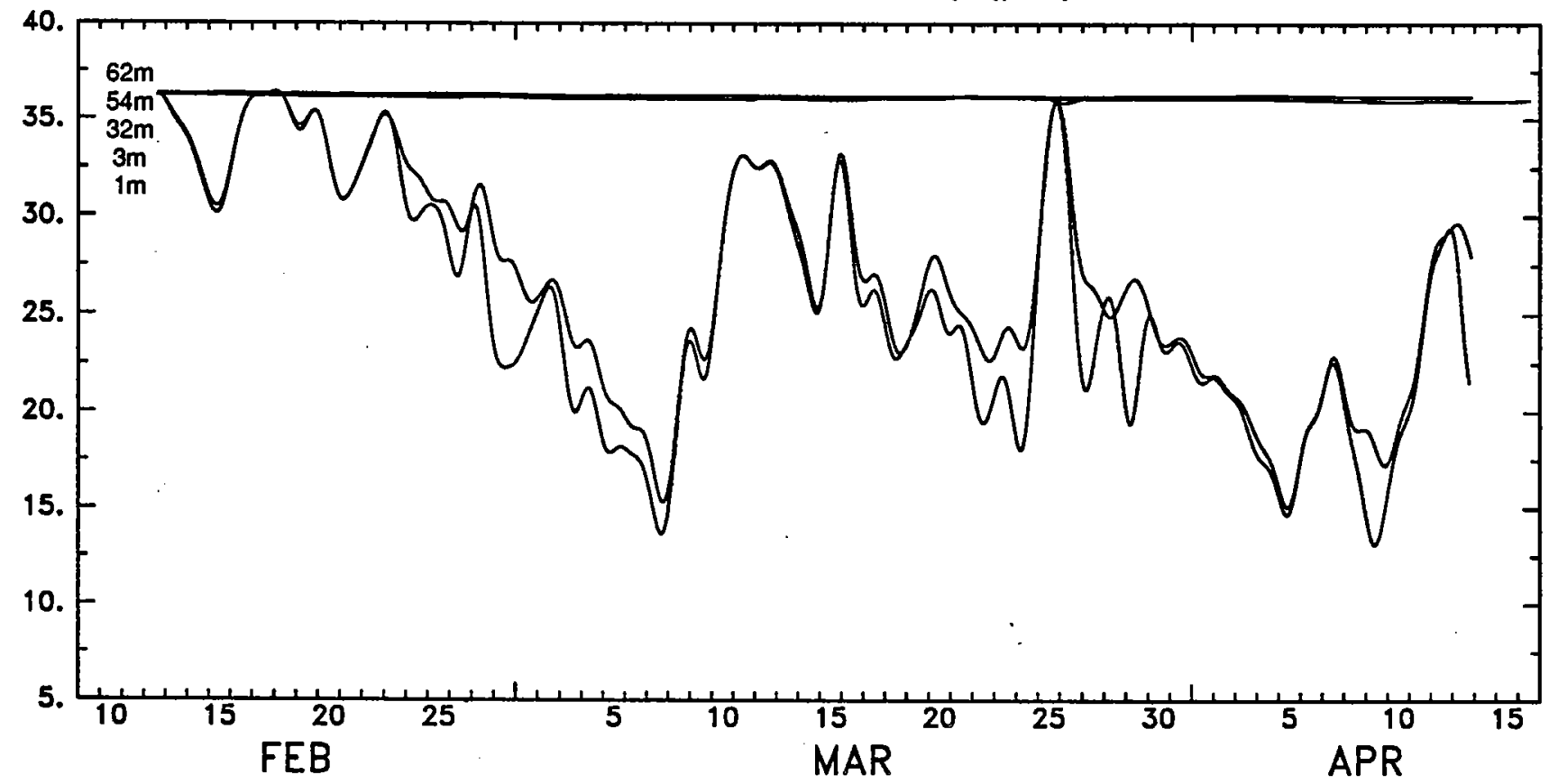


PL64 Low-Pass Filtered Salinity (psu) at M1

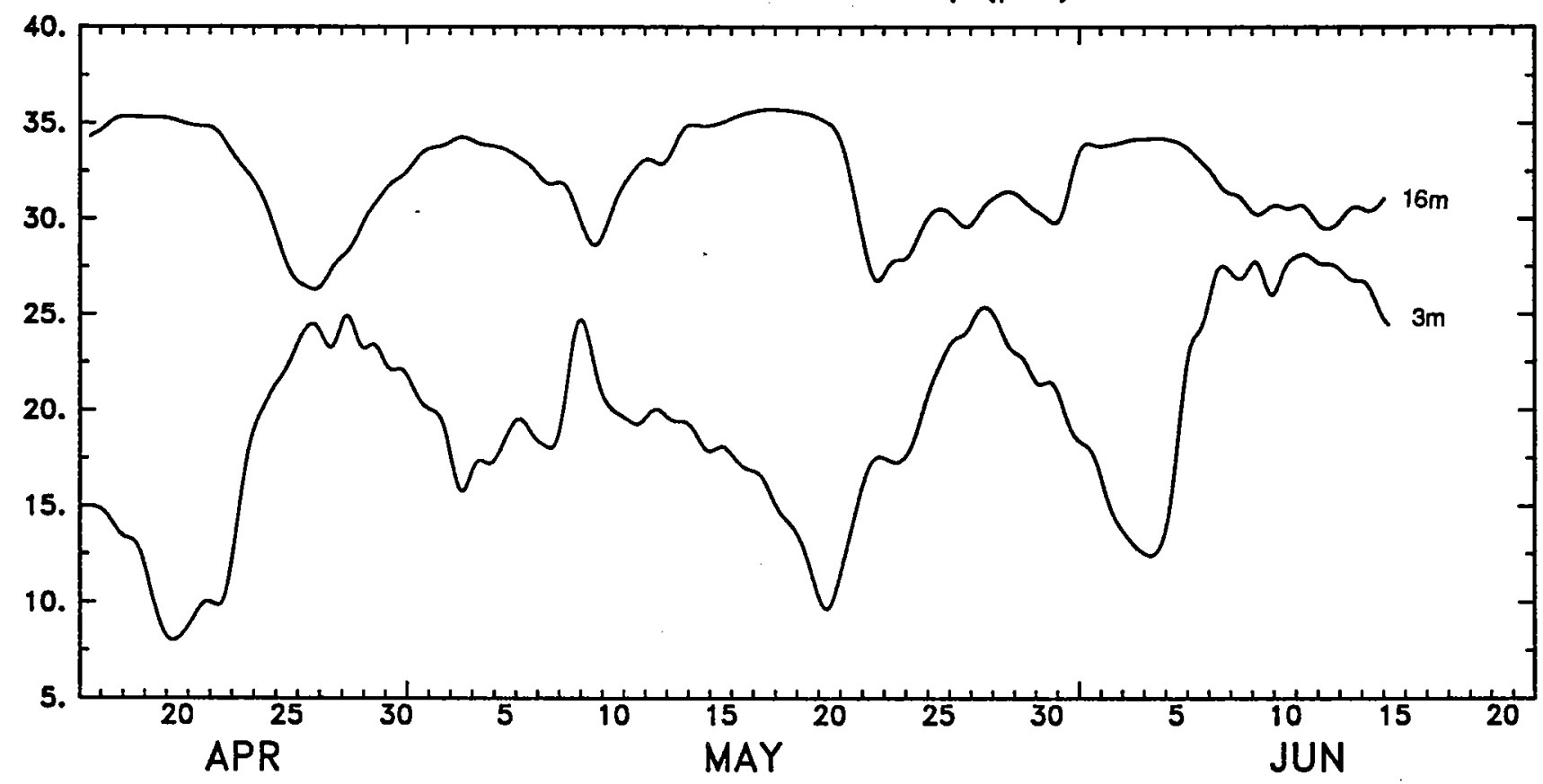

PL64 Low-Pass Filtered Salinity (psu) at M2

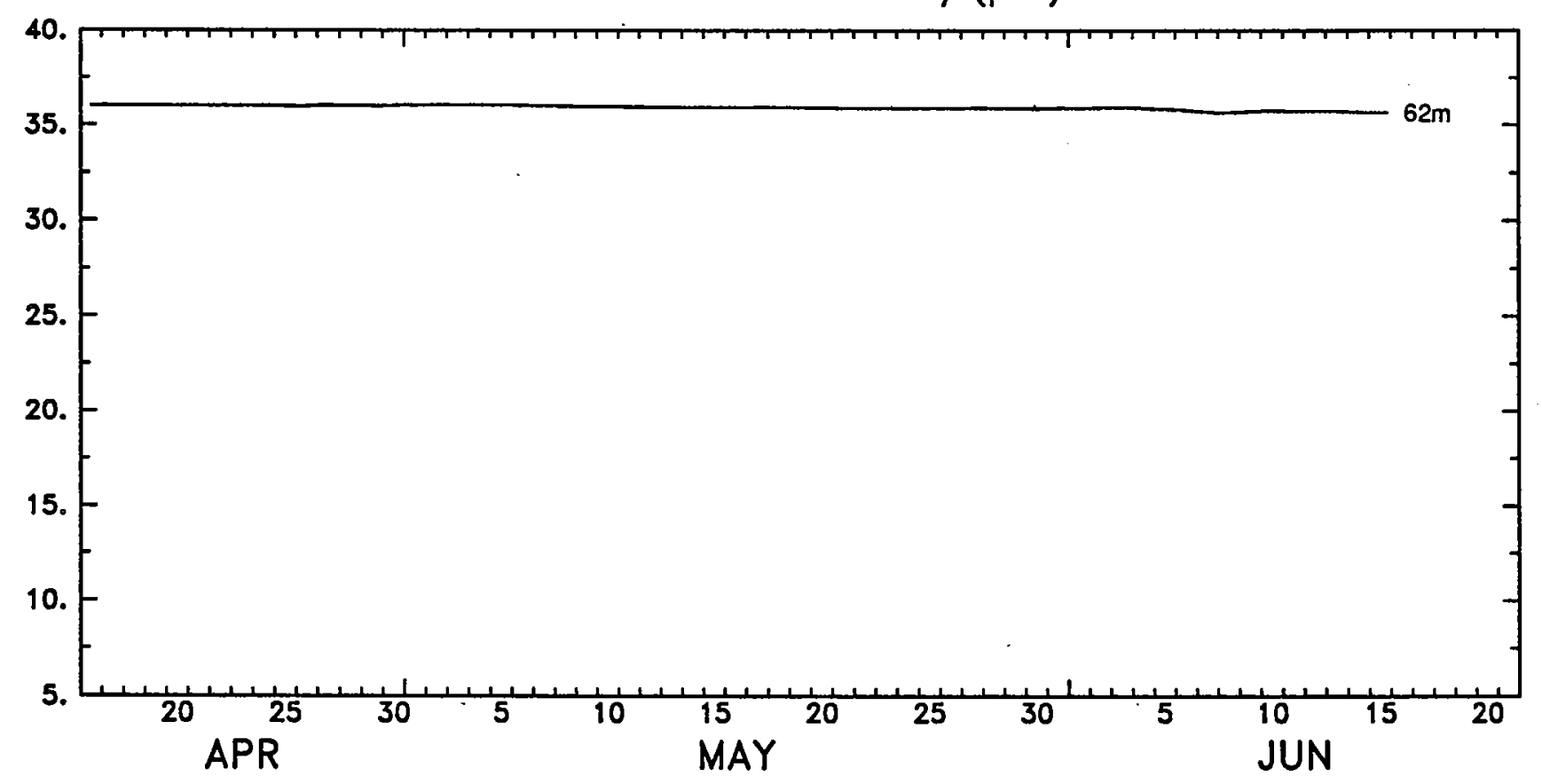


Hourly-Averaged Water Temperature $\left({ }^{\circ} \mathrm{C}\right.$ ) at $\mathrm{M} 1$

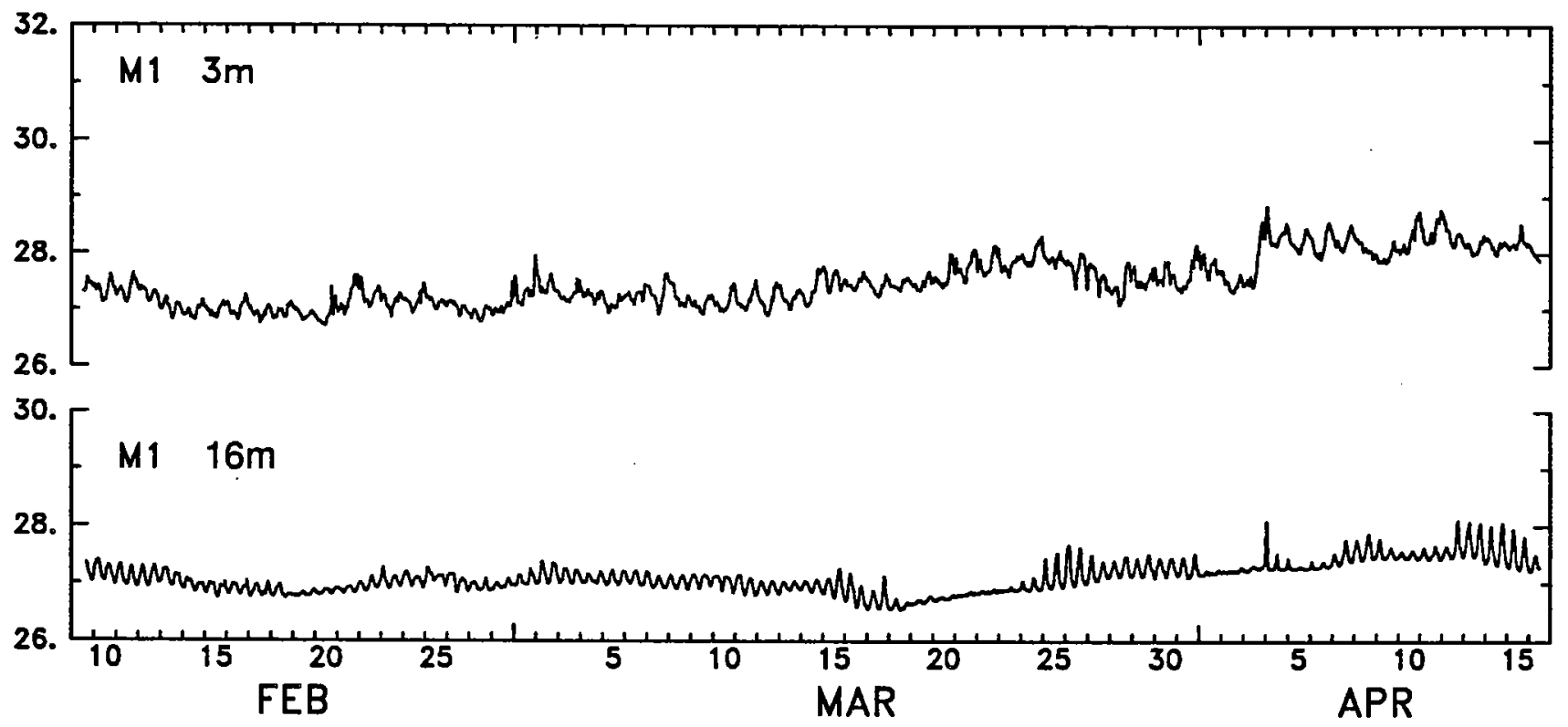


Hourly-Averaged Water Temperature $\left({ }^{\circ} \mathrm{C}\right)$ at $\mathrm{M} 1$

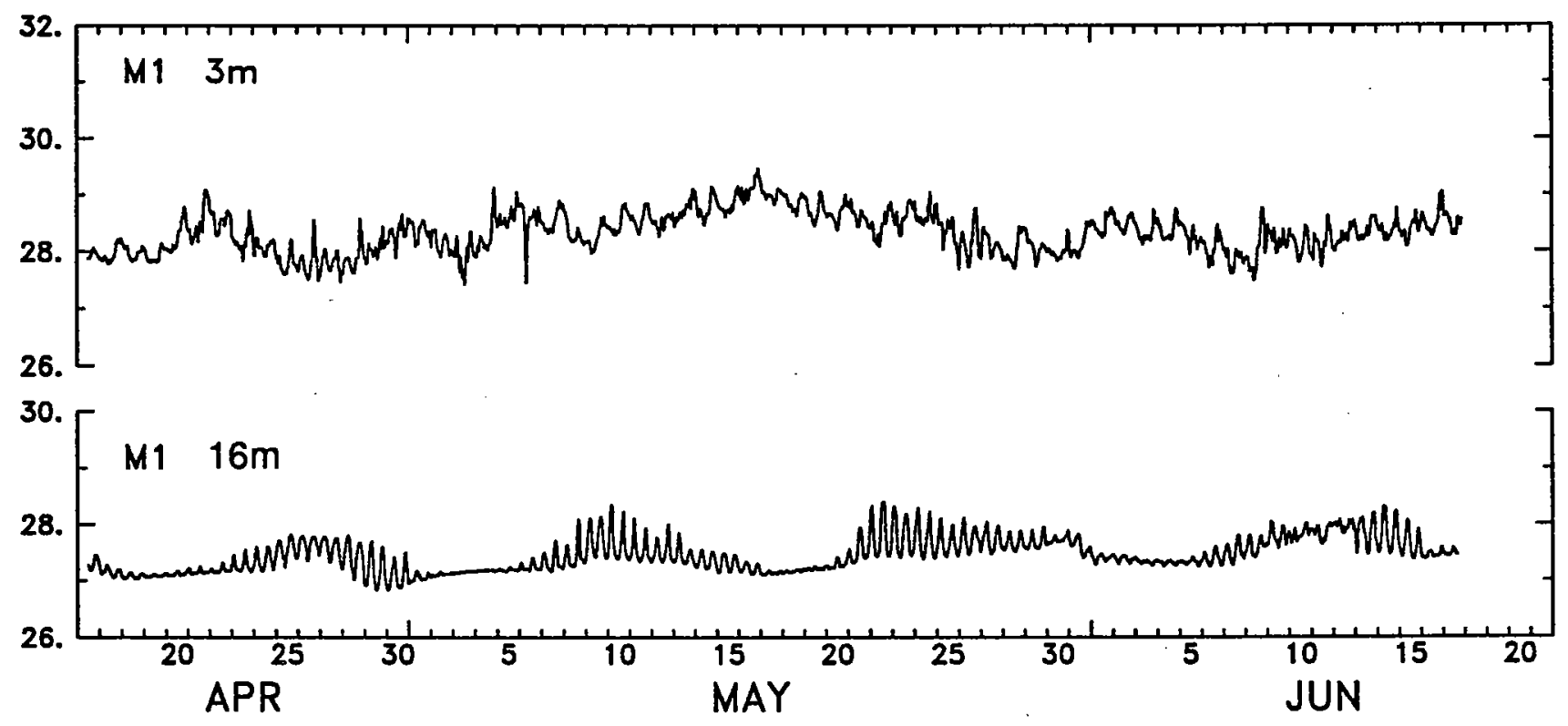


Hourly-Averaged Water Temperature $\left({ }^{\circ} \mathrm{C}\right)$ at $\mathrm{M} 2$
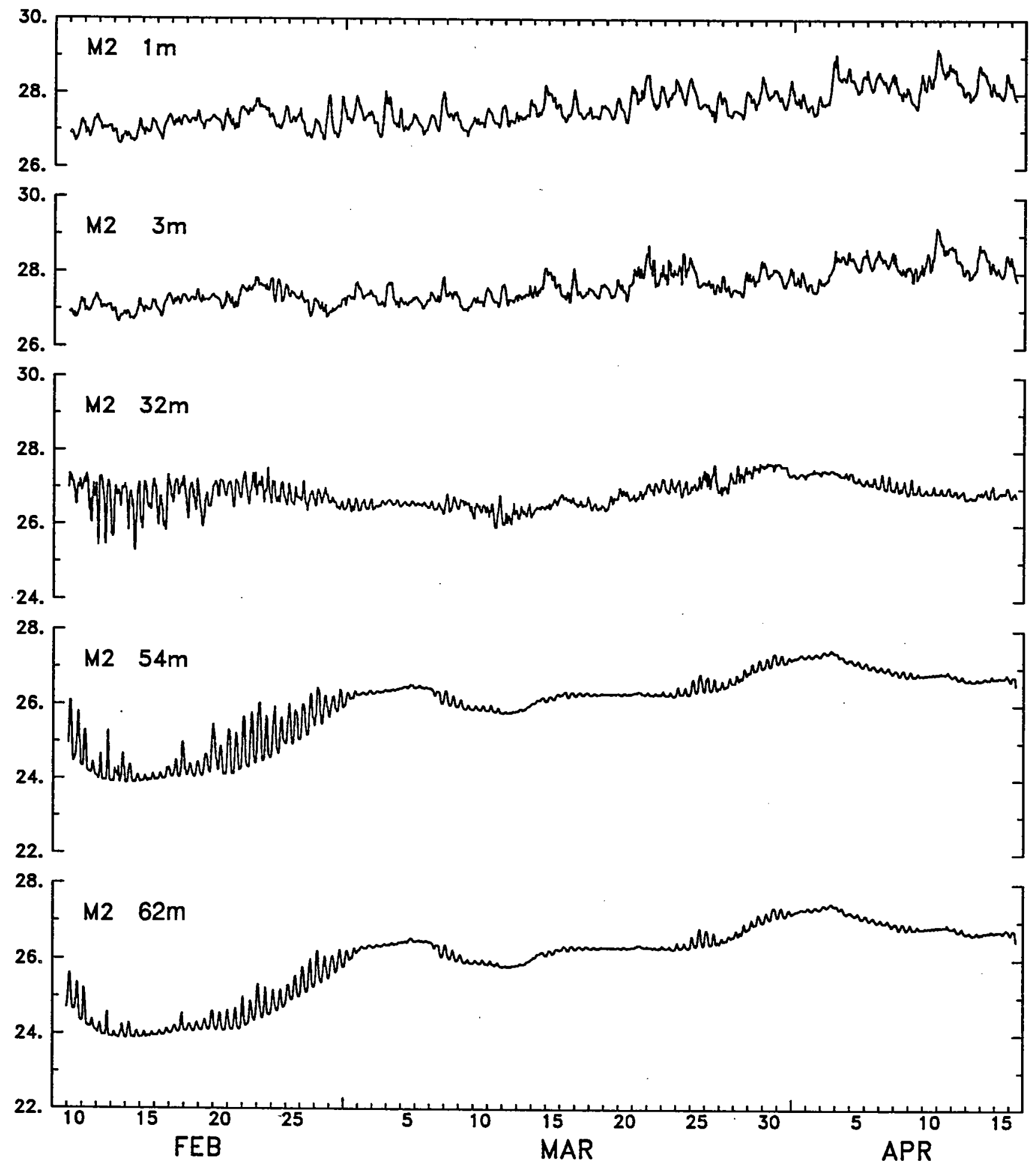
Hourly-Averaged Water Temperature $\left({ }^{\circ} \mathrm{C}\right)$ at $\mathrm{M} 2$
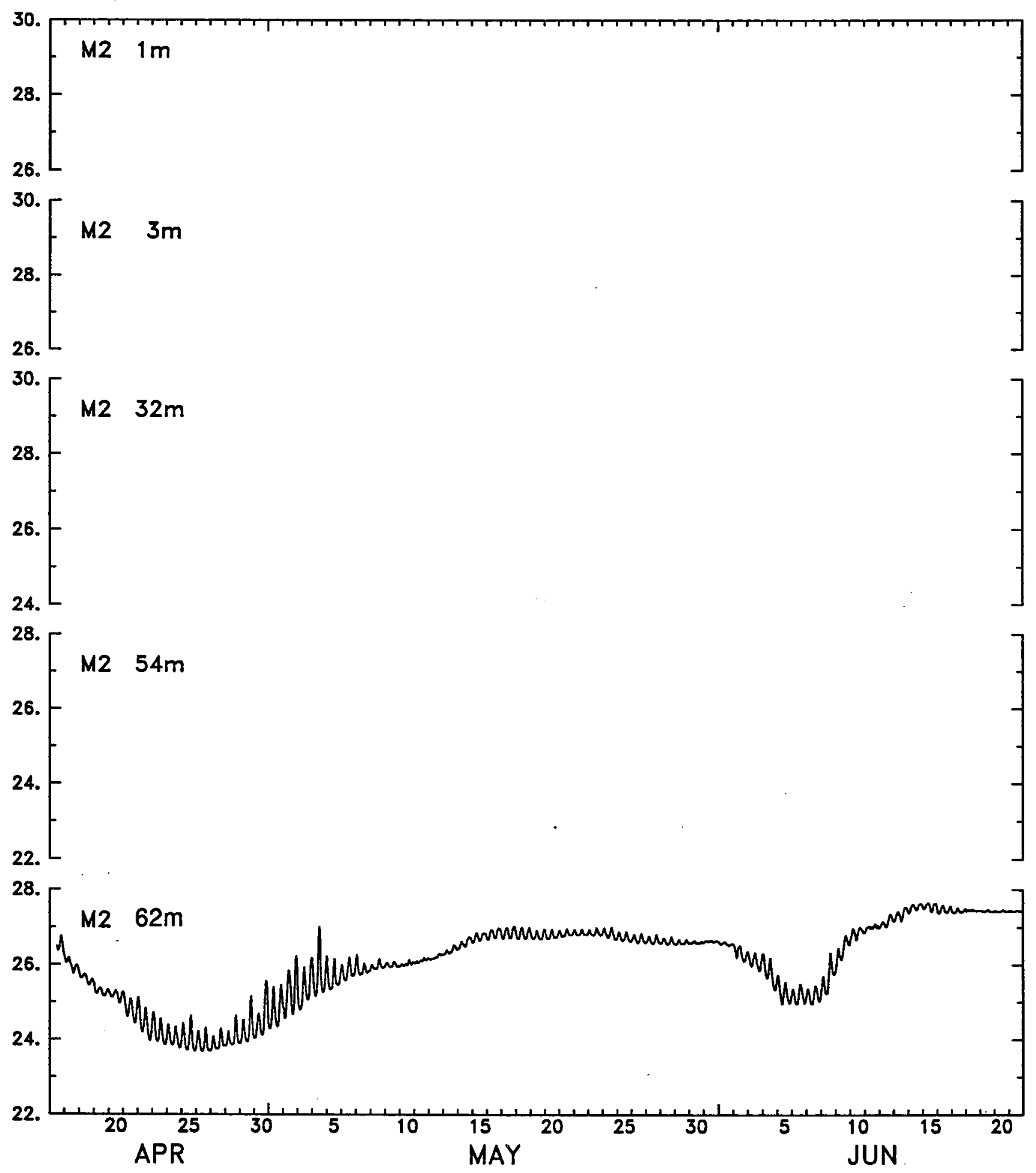
Hourly-Averaged Water Temperature $\left({ }^{\circ} \mathrm{C}\right.$ ) at $\mathrm{M3}$
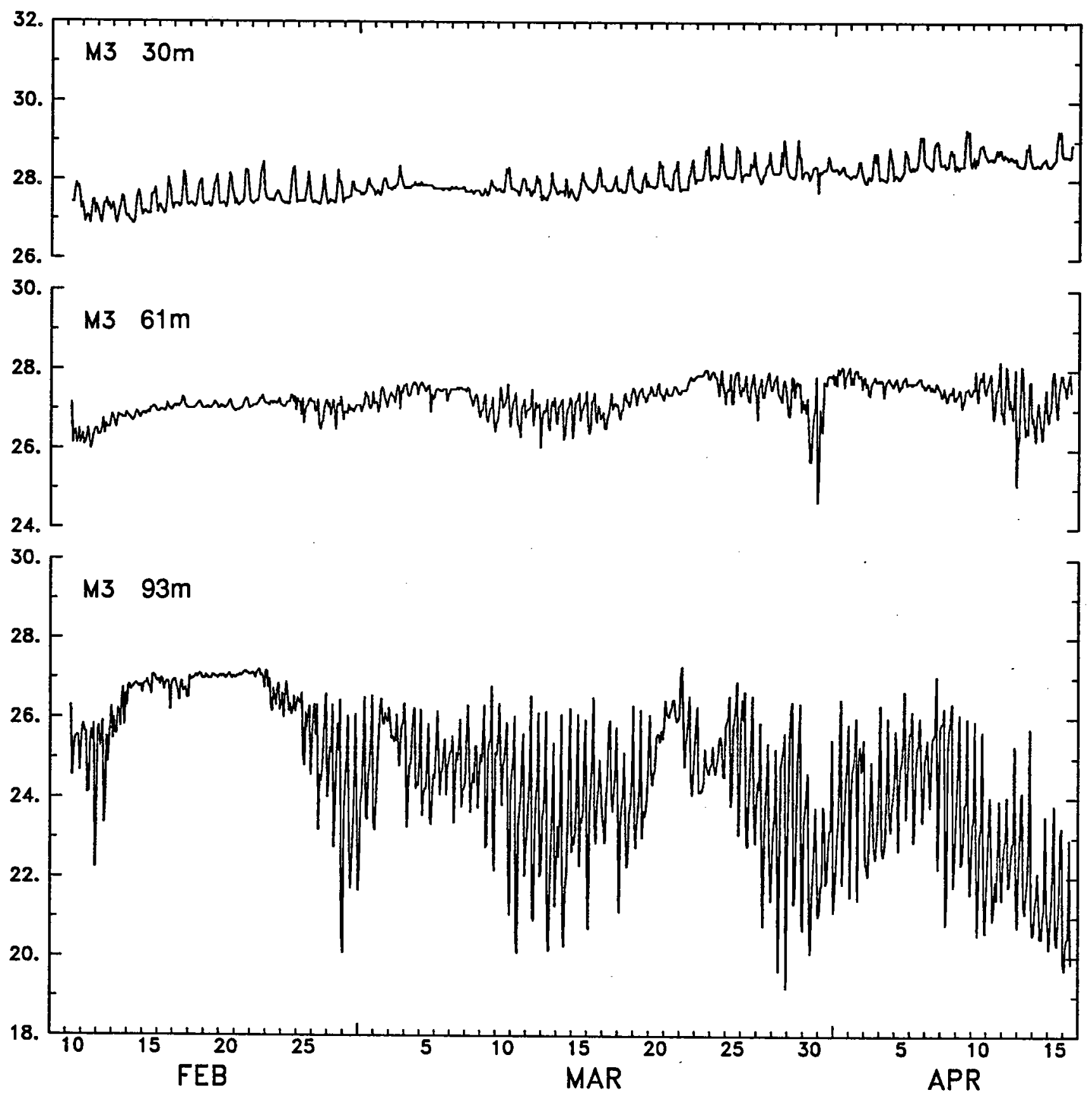
Hourly-Averaged Water Temperature $\left({ }^{\circ} \mathrm{C}\right)$ at $\mathrm{M} 3$

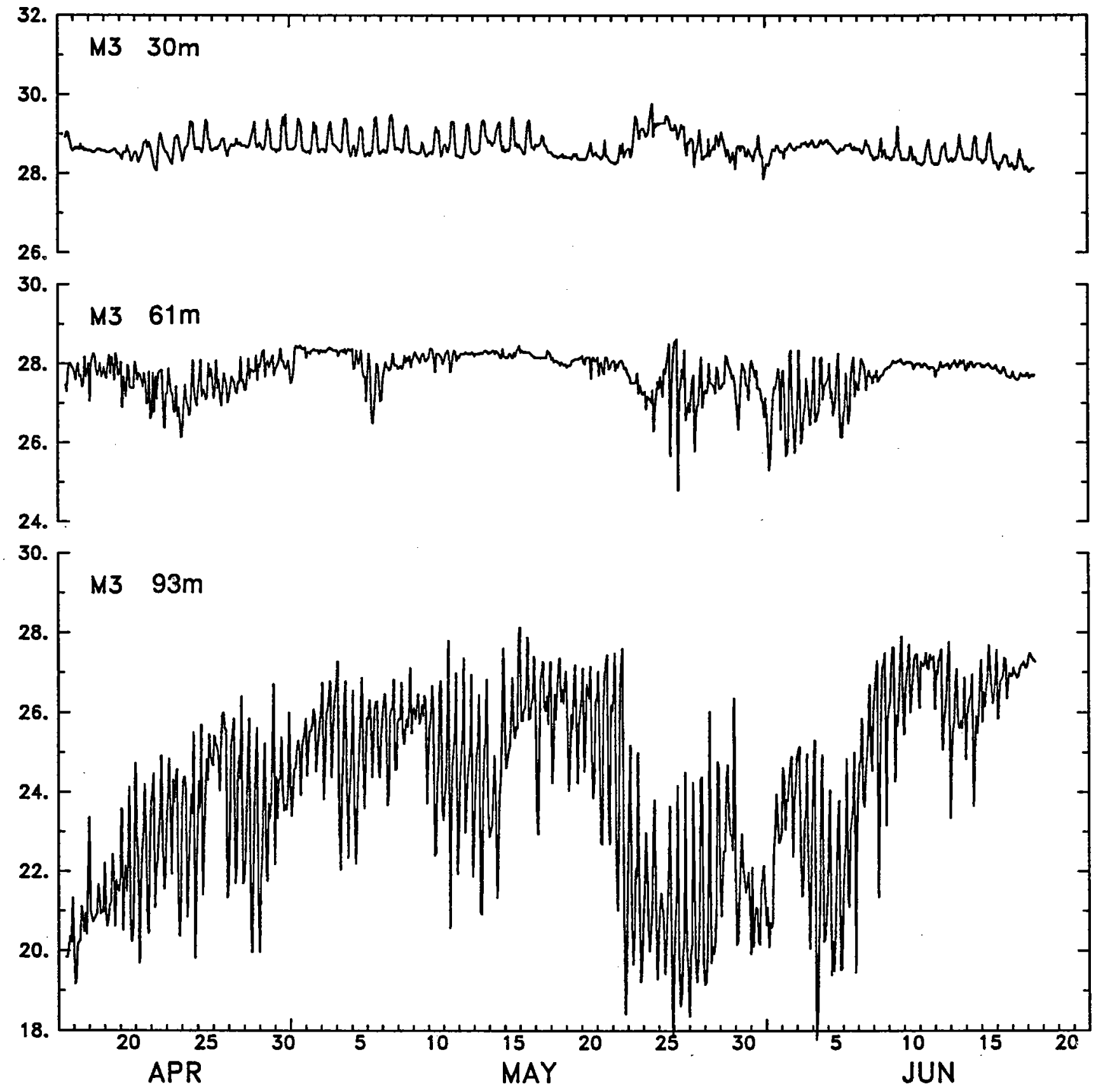


Hourly-Averaged Salinity (psu) at M1

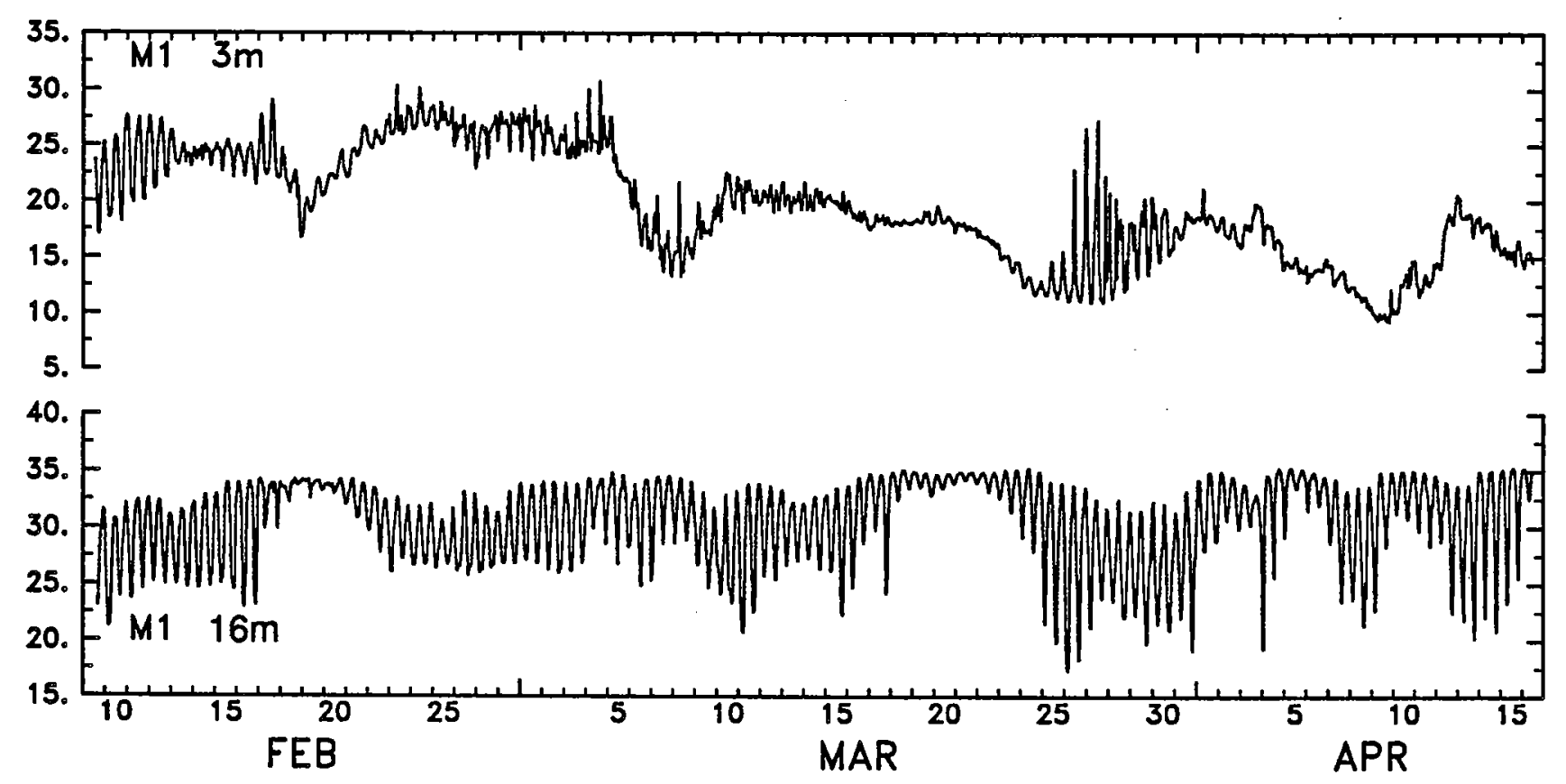


Hourly-Averaged Salinity (psu) at M1

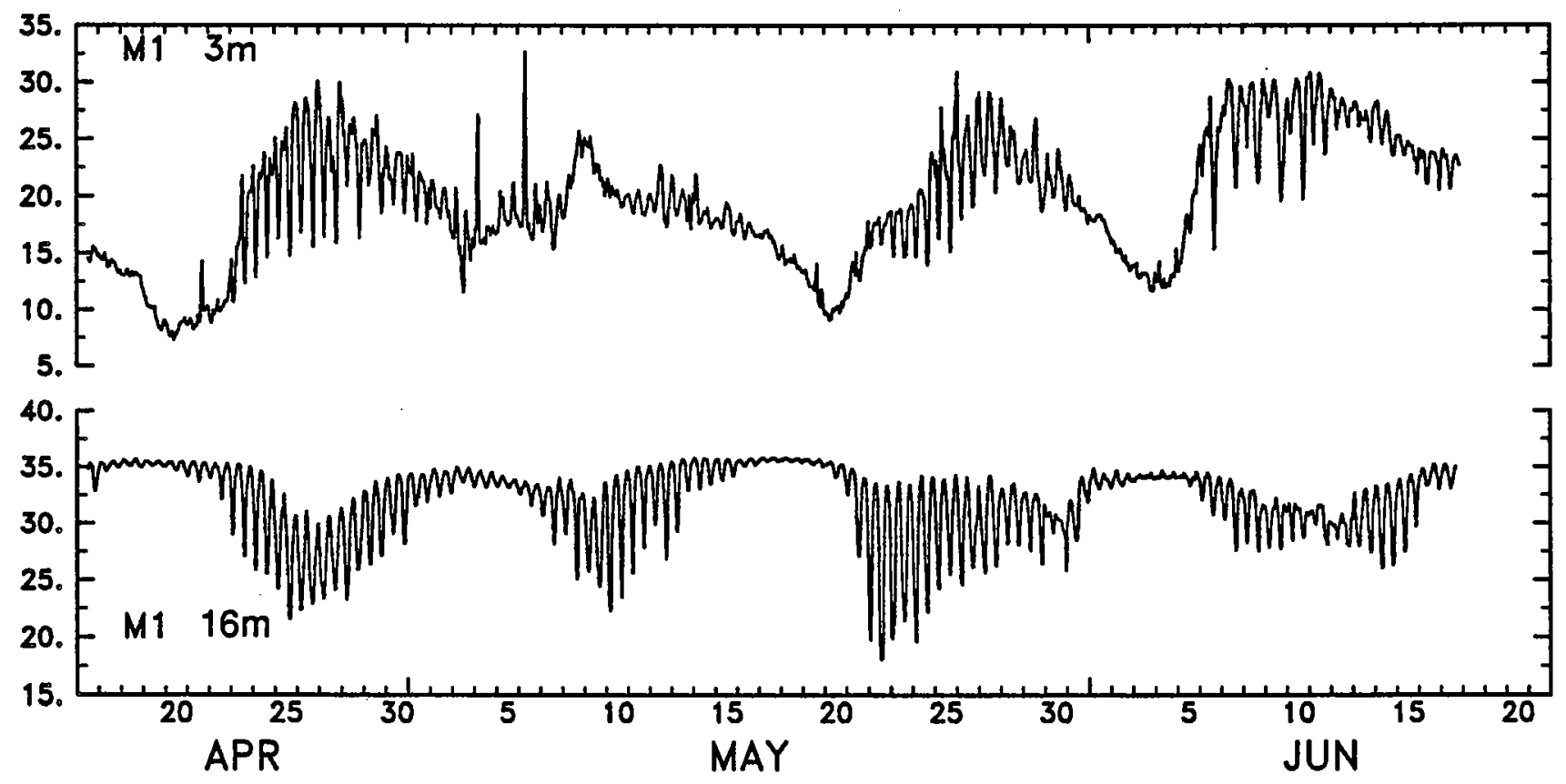


Hourly-Averaged Salinity (psu) at M2
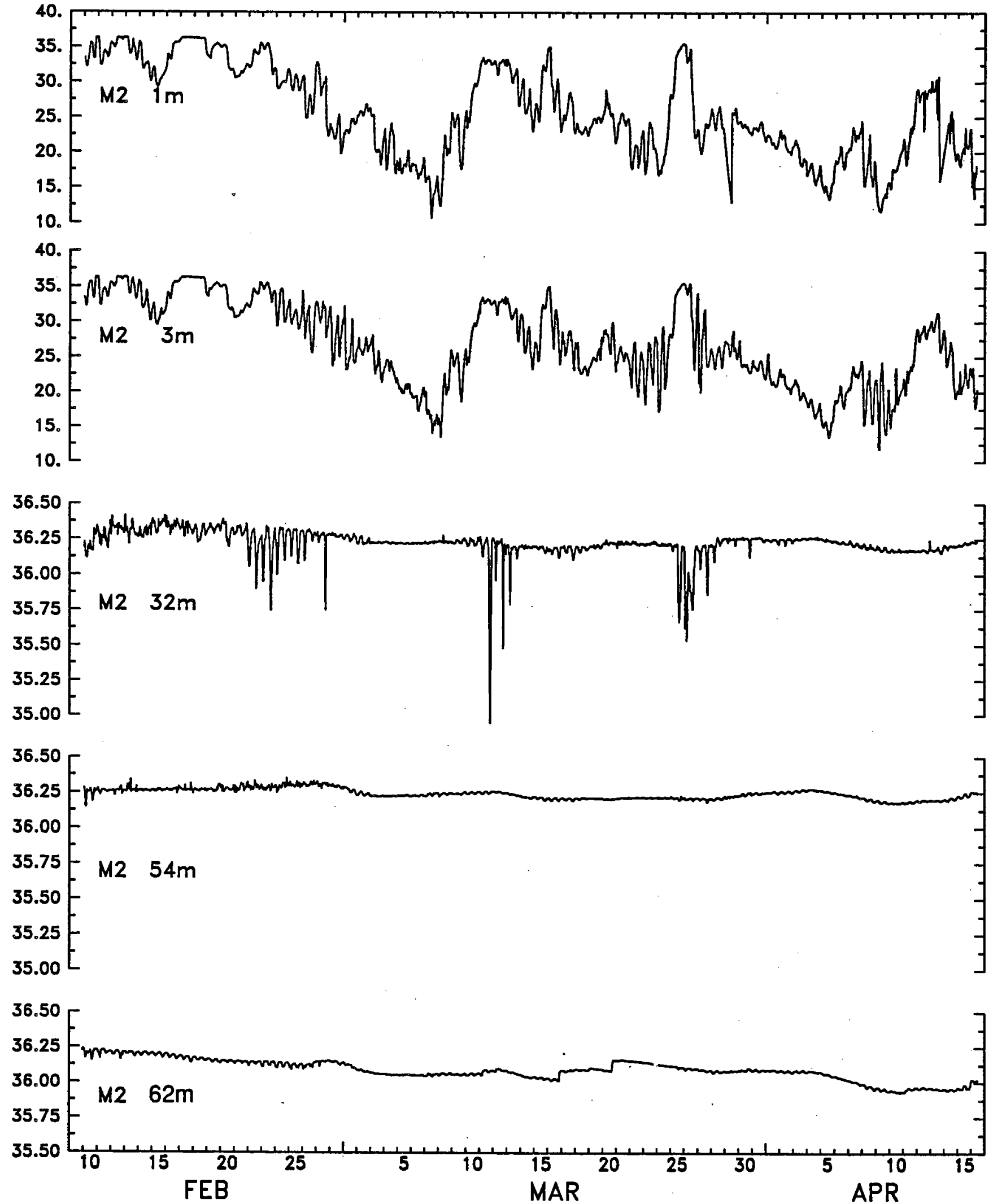
Hourly-Averaged Salinity (psu) at M2
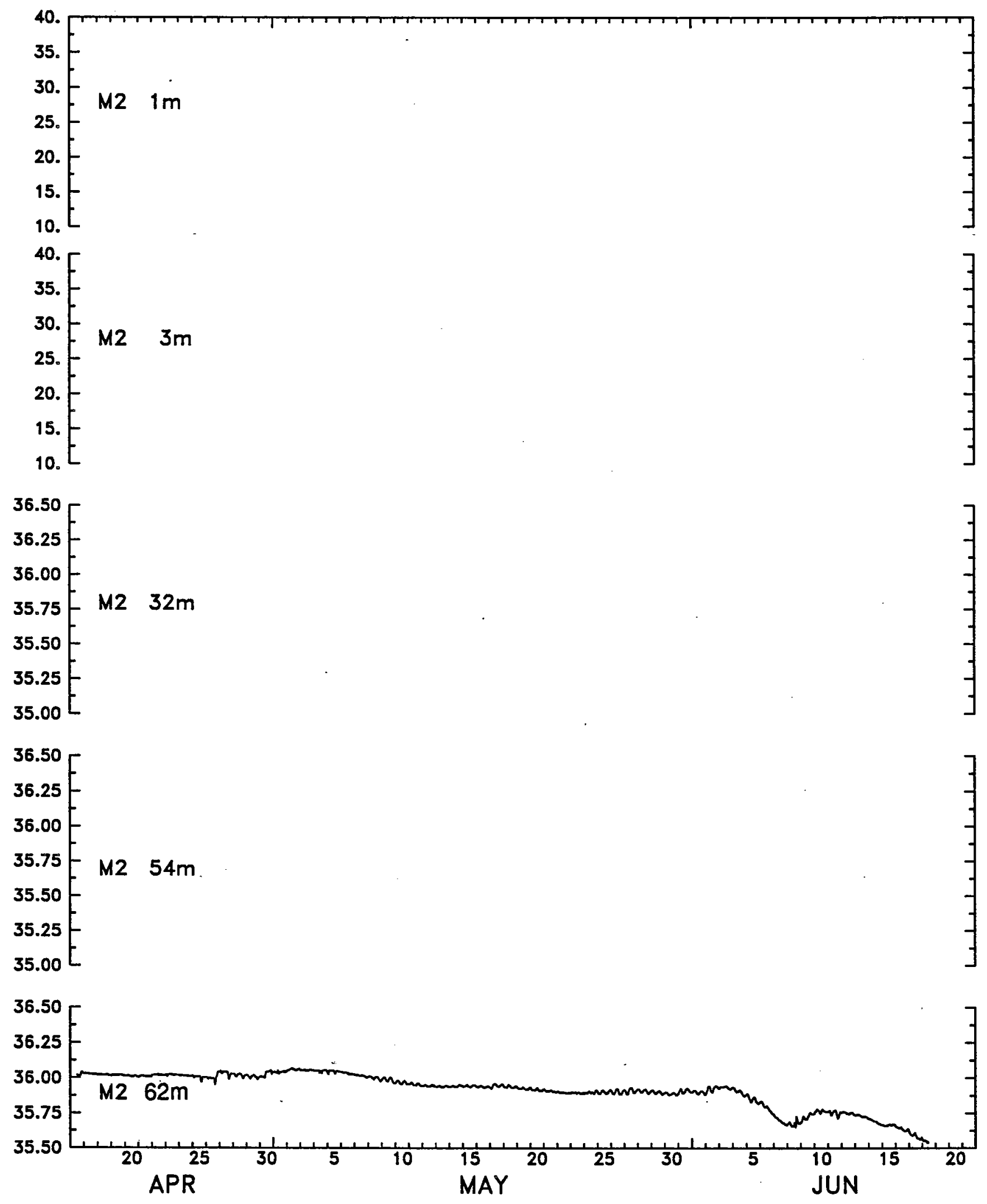

Figure 27 (cont.) 
Hourly-Averaged Conductivity $(\mathrm{s} / \mathrm{m})$ at $\mathrm{M} 1$

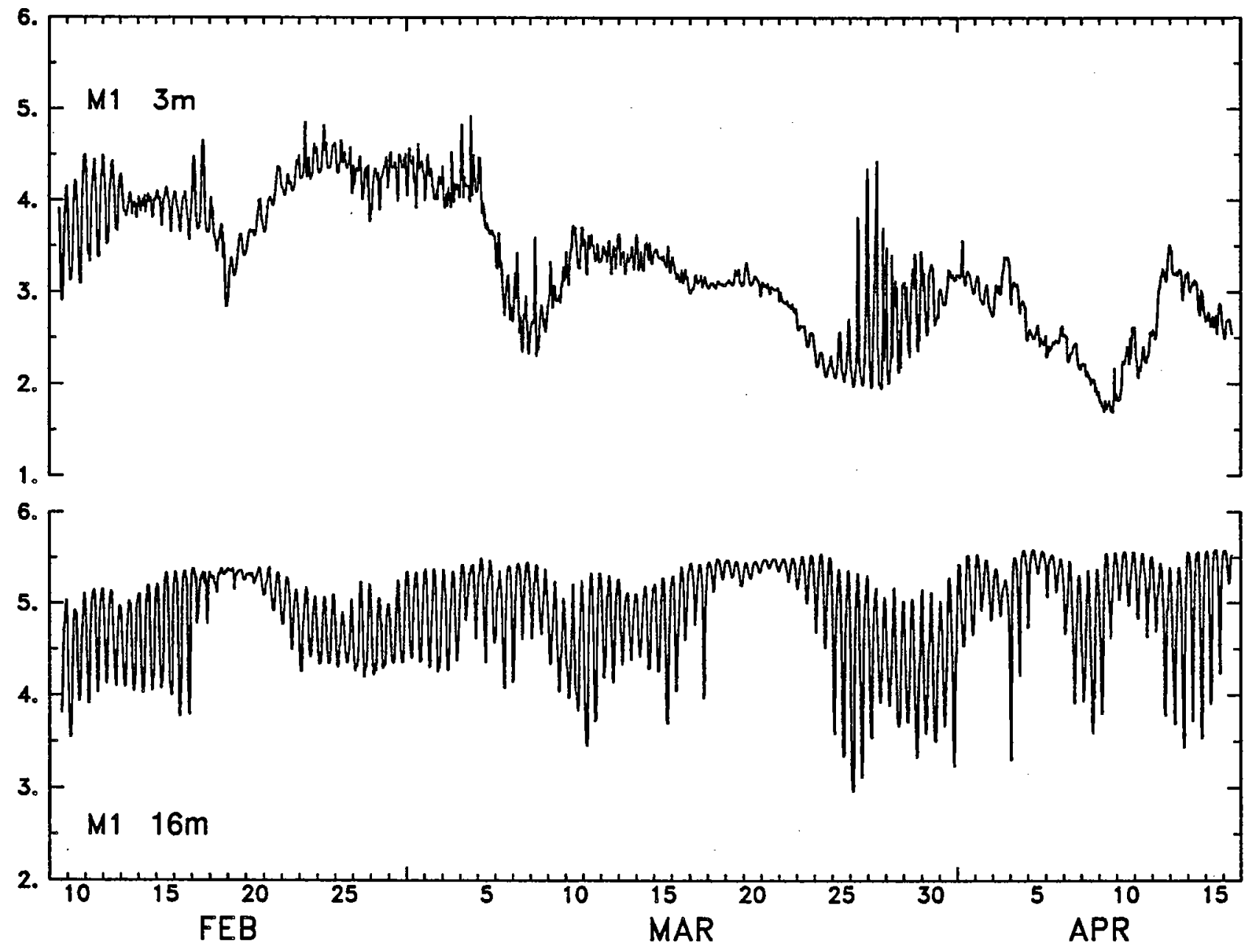


Hourly-Averaged Conductivity $(\mathrm{s} / \mathrm{m})$ at $\mathrm{M} 1$
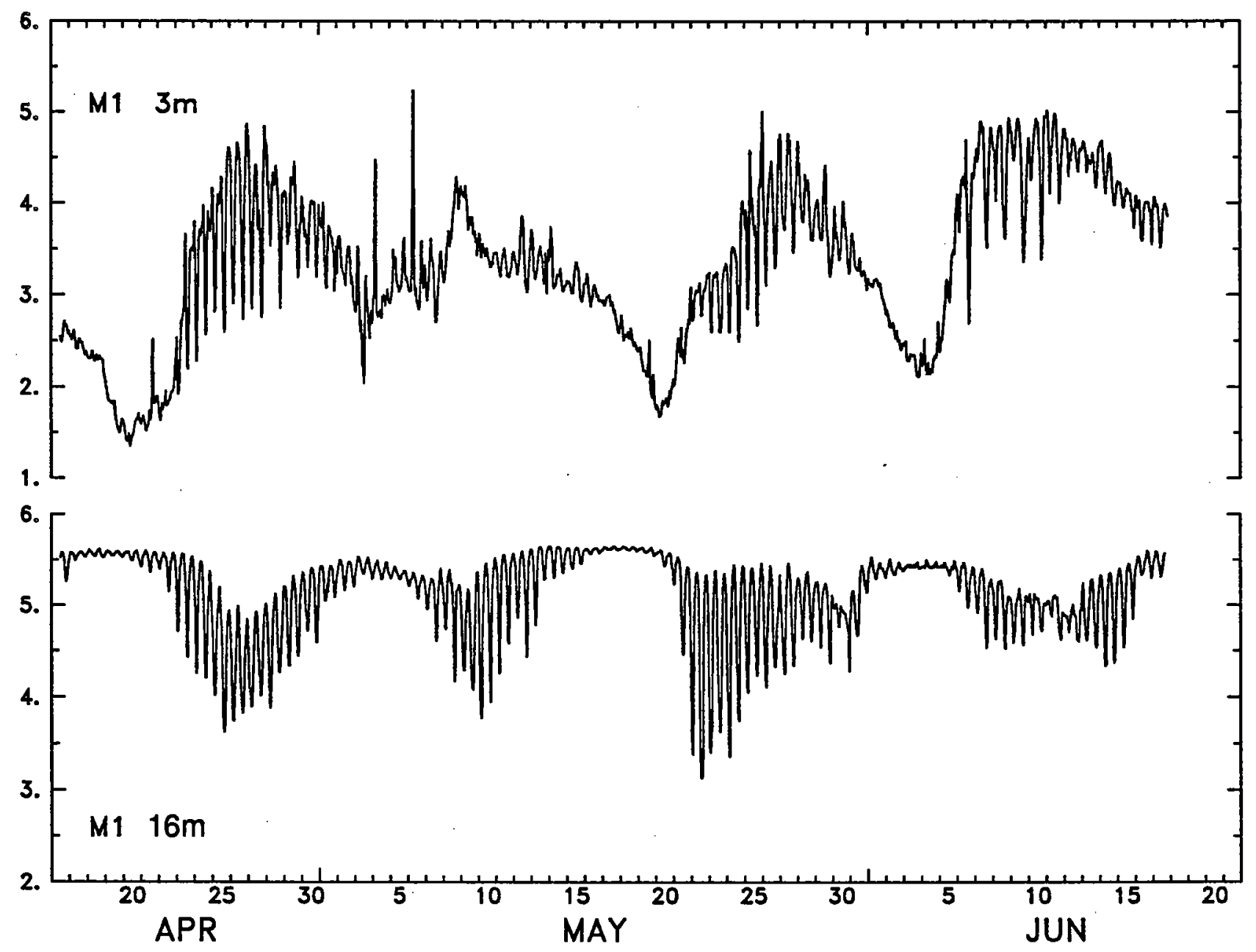
Hourly-Averaged Conductivity $(\mathrm{s} / \mathrm{m})$ at $\mathrm{M} 2$
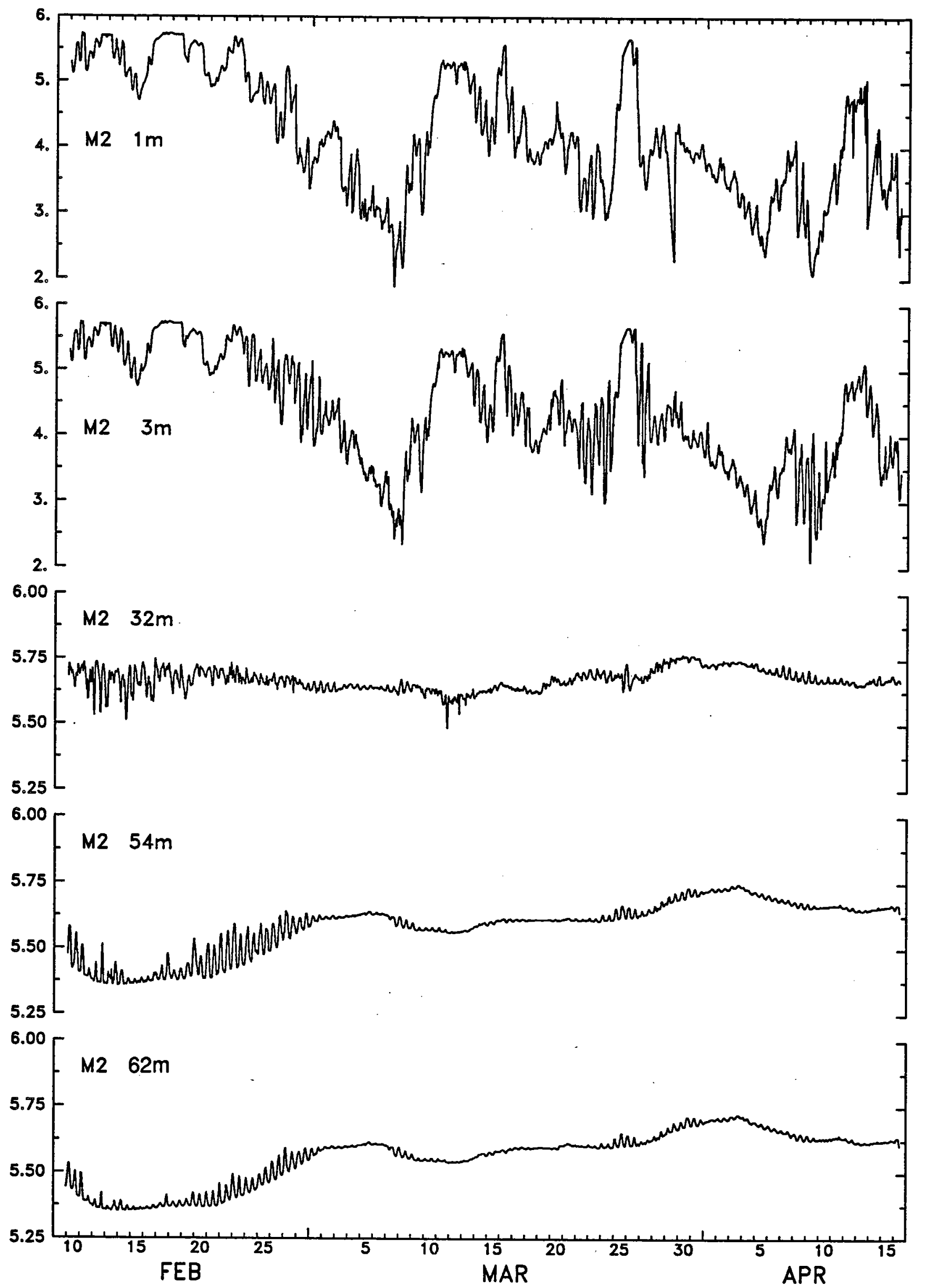

Figure 29 
Hourly-Averaged Conductivity $(\mathrm{s} / \mathrm{m})$ at $\mathrm{M} 2$

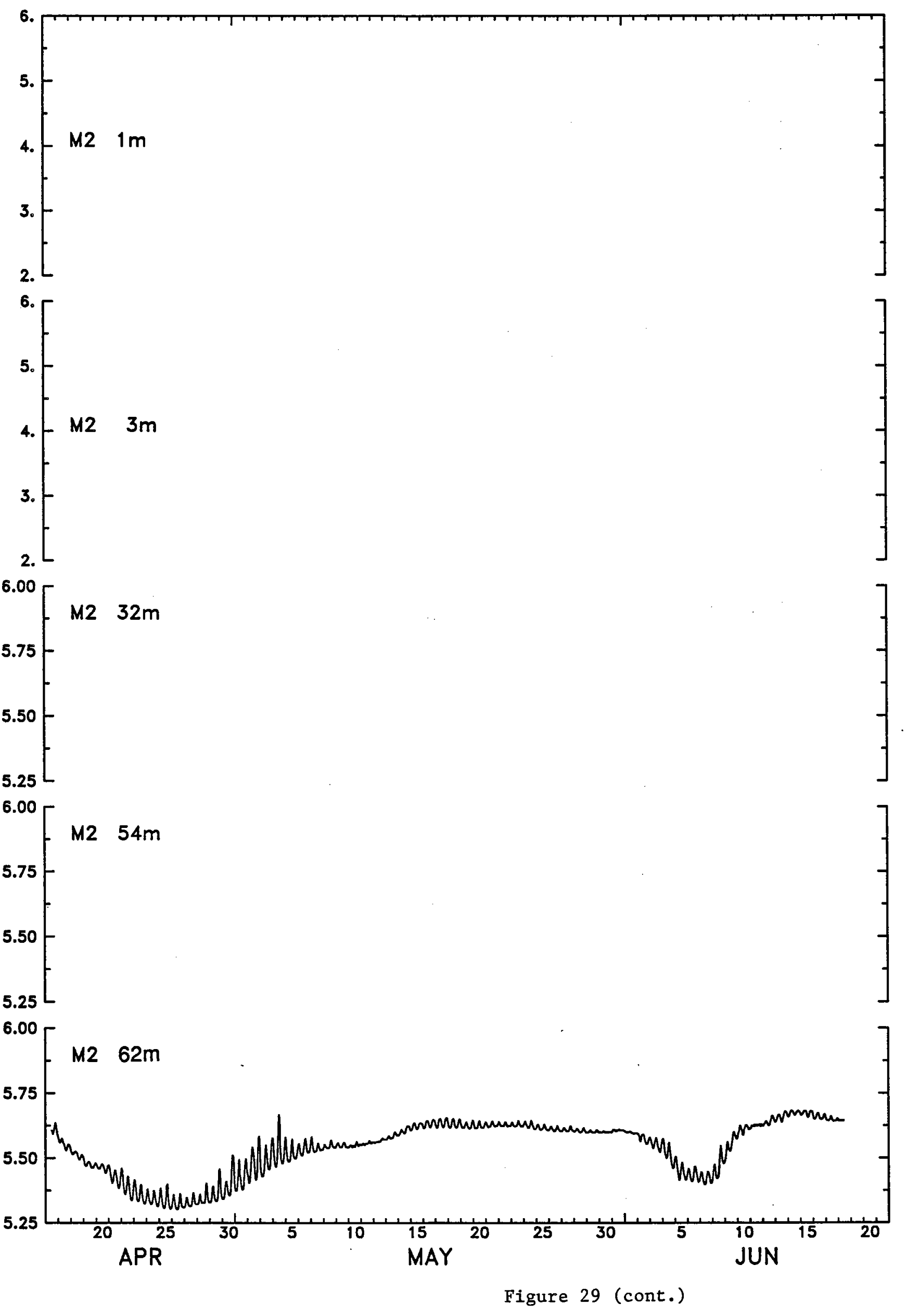




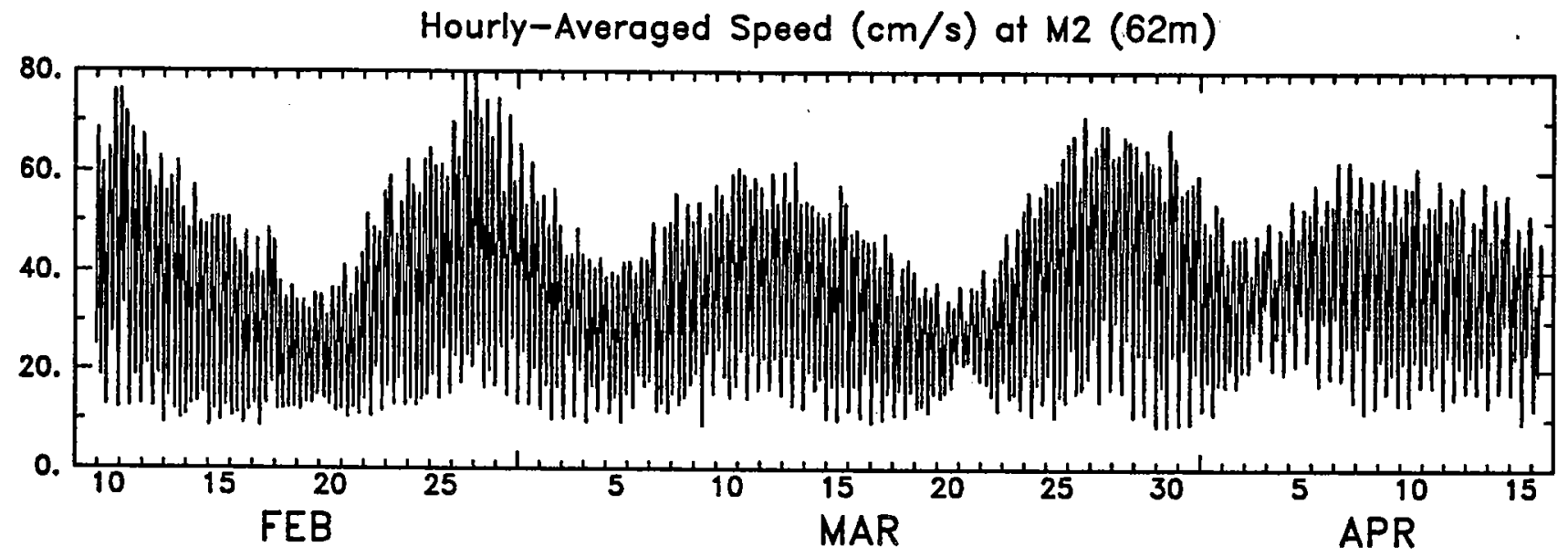

Hourly-Averaged Speed $(\mathrm{cm} / \mathrm{s})$ at $M 2(64 \mathrm{~m})$

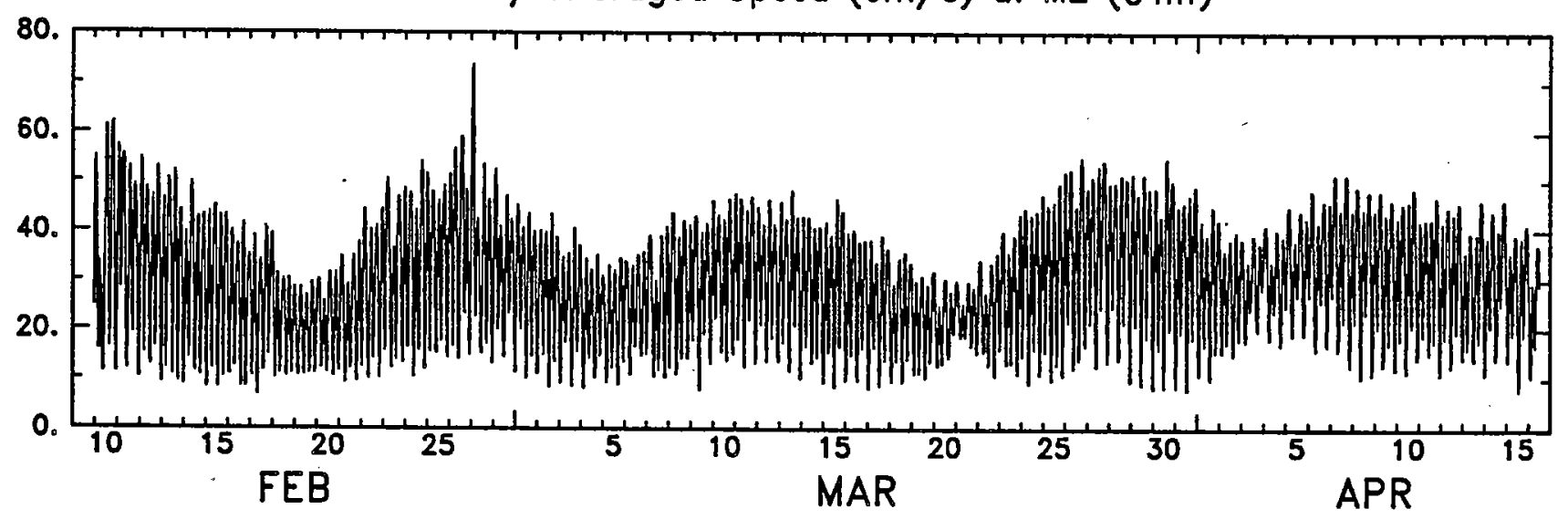

PL64 Low-Pass Filtered Speed $(\mathrm{cm} / \mathrm{s})$ at M2 (62m - solid) and M2 (64m - dash)

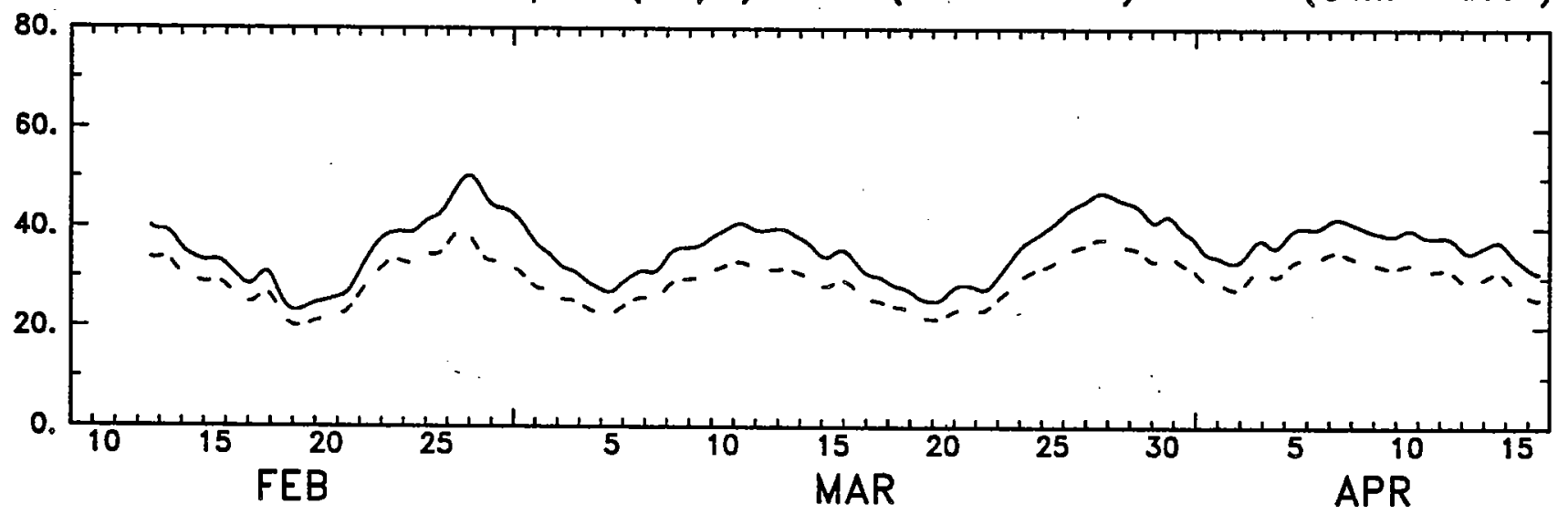


Hourly-Averaged Speed $(\mathrm{cm} / \mathrm{s})$ at M2 $(62 \mathrm{~m})$

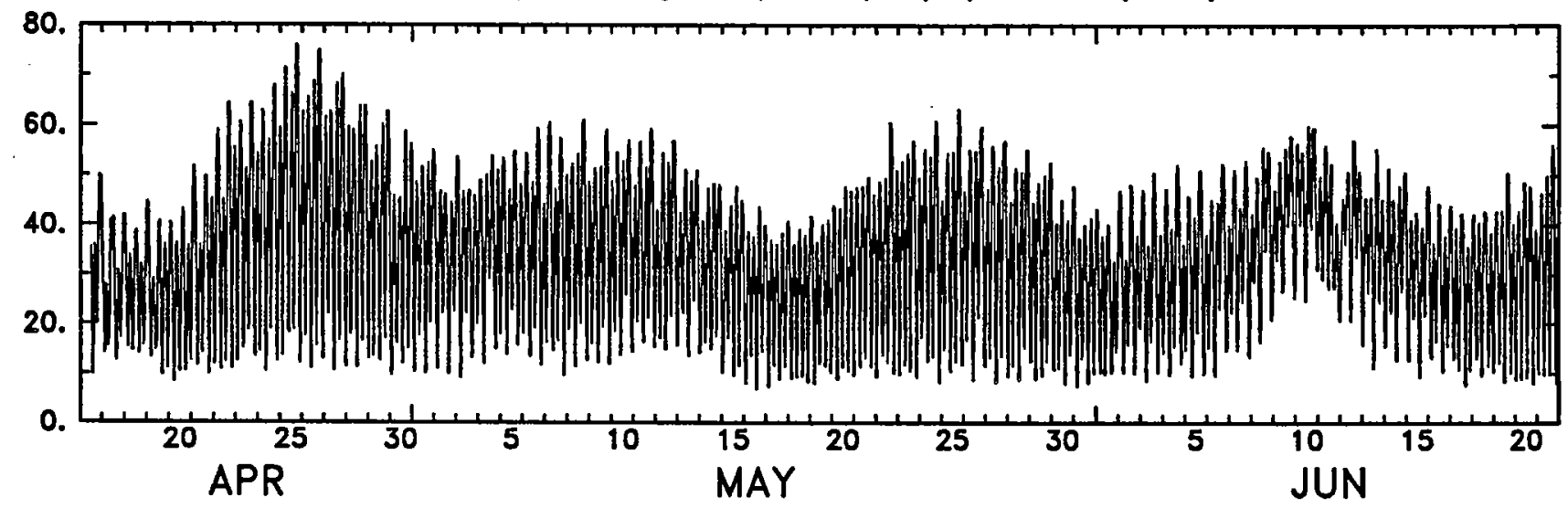

Hourly-Averaged Speed $(\mathrm{cm} / \mathrm{s})$ at $M 2(64 \mathrm{~m})$

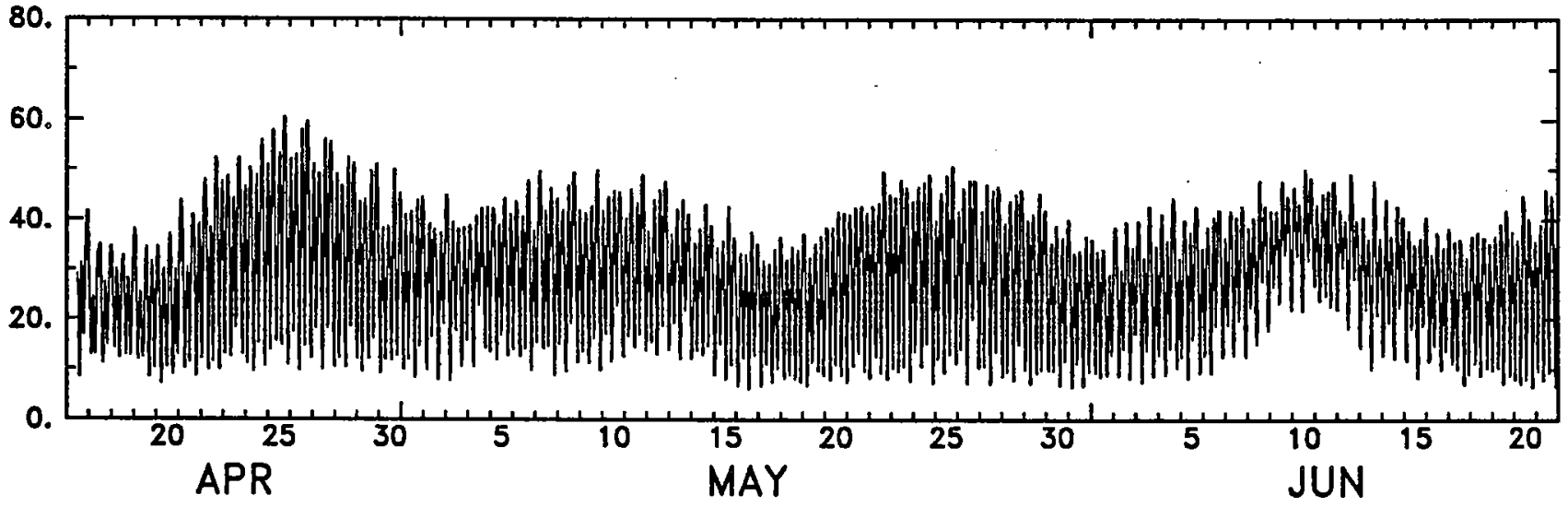

PL64 Low-Pass Filtered Speed (cm/s) at M2 (62m - solid) and M2 (64m - dash)

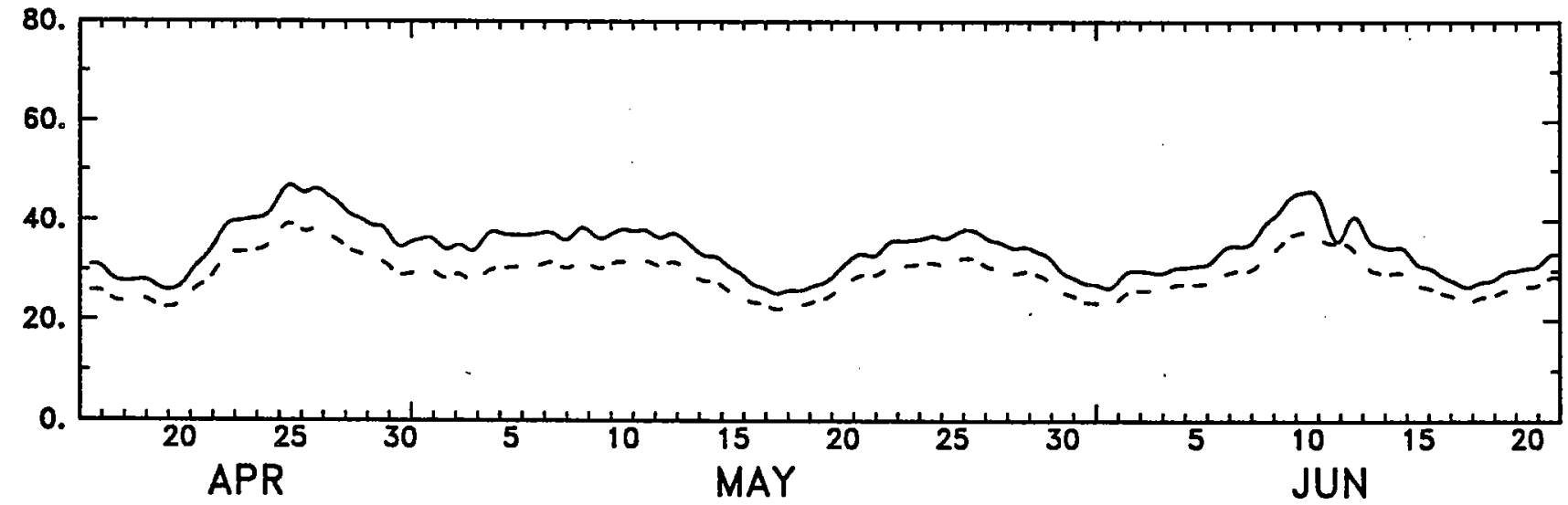


Hourly-Averaged Pressure (db) of M2 (62m)

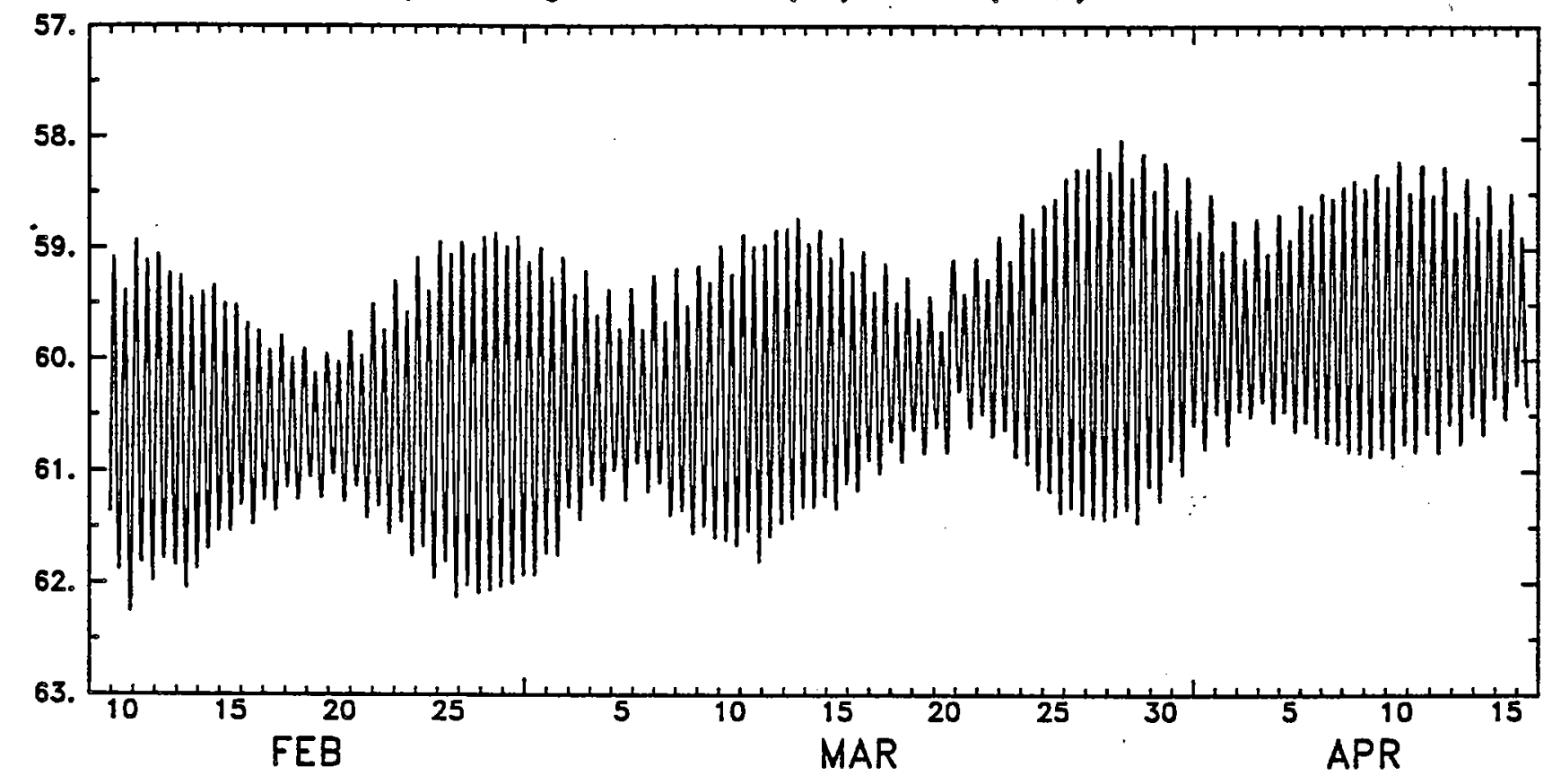


Hourly-Averaged Pressure (db) at M2 (62m)

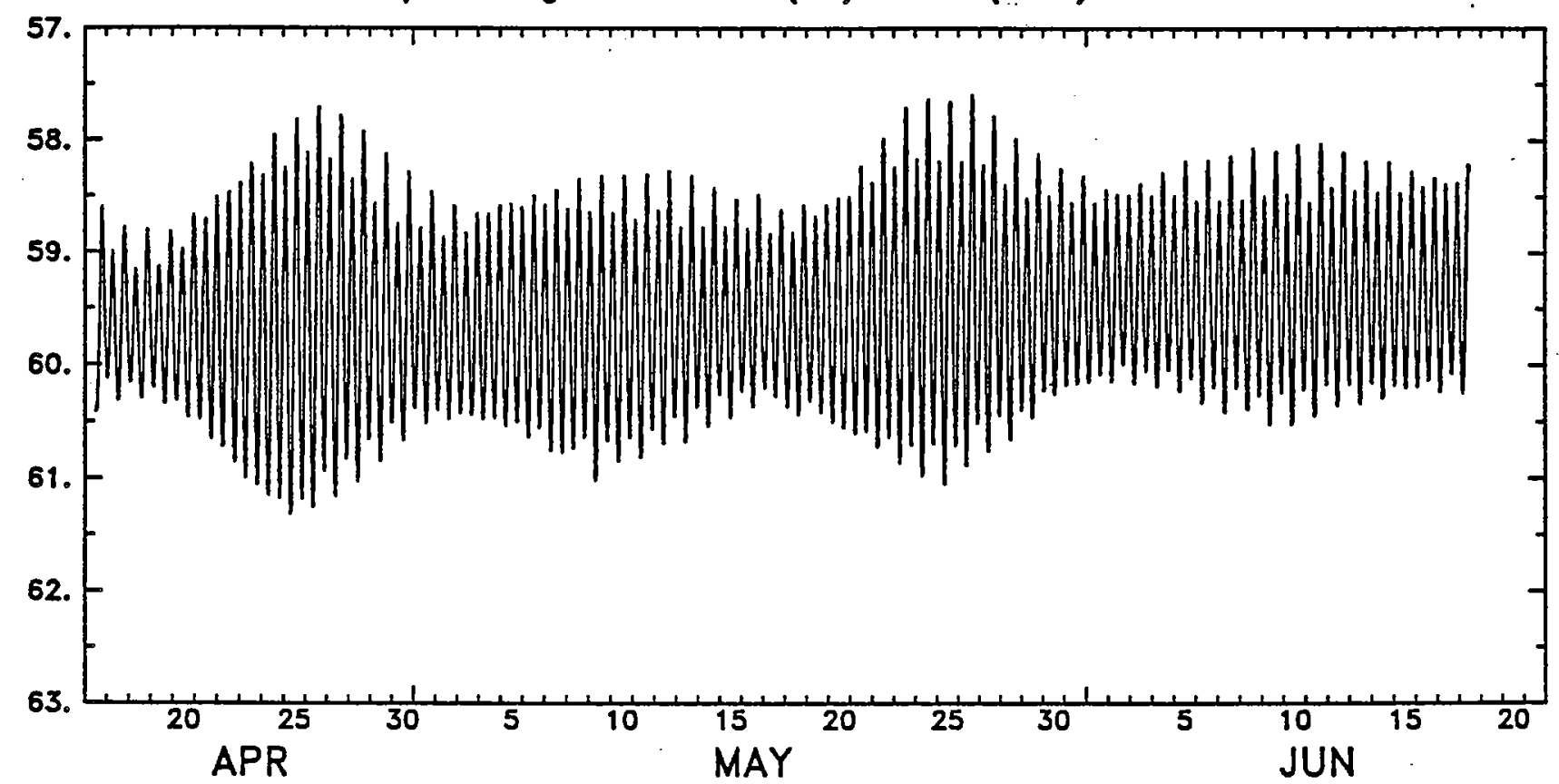




\section{Appendix: Evaluation of the AmasSeds M3 Current Meter Data}

The AmasSeds M3 mooring supported four current meters. There was a WHOI S4 current meter measuring speed, direction, and pressure deployed at a static (no mooring dip) depth of $32 \mathrm{~m}$, then three identical Norwegian-built SD2000 current meters deployed at static depths of 30,61 , and $93 \mathrm{~m}$. Mean water depth at the M3 site was approximately $103 \mathrm{~m}$. Each SD2000 measured speed, direction and temperature. Two problems with the M3 current meter data are examined below, the impact of mooring tilt on the S4 current measurements and differences in observed currents between the top SD2000 and the S4 which were separated by $2.75 \mathrm{~m}$ in the vertical. The S4 current sensors have a cosine response in the vertical, thus the recorded S4 speed is equal to the true horizontal speed multiplied by the cosine of the instrument tilt. This effect can be corrected if an empirical relationship between mooring dip and instrument tilt can be established. The SD2000 was mounted to its support cage with a universal joint so that the current meter housing would stay aligned horizontally into the flow independent of the vertical orientation of its support rod.

The S4 measured pressure which gives a record of the dip of the M3 mooring in the strong tidal and NBC flows. Based on this pressure time series during the first 80 days of deployment when both current meters seemed to function normally (this will be discussed later), the mean S4 pressure when the $\mathrm{S} 4$ speed was less than $60 \mathrm{~cm} / \mathrm{s}$ (and the mooring is assumed to be upright or close to upright) was subtracted from the original pressure time series to give the instantaneous dip time series (Figure A1) which shows both the high-frequency pressure fluctuations caused by the tides and a larger subtidal variation due to the subtidal current fluctuations. The maximum surface tide amplitude at M3 is about $1.4 \mathrm{~m}$ based on Flagg and McDowell (1981).

Using the S4 (32 $\mathrm{m})$ and bottom SD2000 (93 m) current data, simple representative unidirectional velocity profiles were constructed (Table A1) and used as input into a static mooring dynamics model (Moller, 1976) to develop empirical relationships between S4 dip, tilt, and speed for four sets of model drag coefficients (Table A2). Models A-D differ only in the drag coefficient used for the vertical mooring line components (wire rope, chain, and nylon) and what percentage of the wire rope was faired. The model results for S4 dip versus speed are shown in Figure A2 superimposed on the S4 data. The close agreement between the model A predicted dip and the observed dip suggests that model $\mathrm{A}$ is the most realistic of the four models considered. Model A features a large drag coefficient $\left(c_{d}=2.6\right)$ recently found to be optimal in mooring studies conducted at Bedford Institute of Oceanography (G. Tupper, personal communication). Why this large drag coefficient produced the most realistic predictions when the M3 wire rope was deployed with fairing is a mystery. Using model A to determine a simple empirical relationship between $\mathrm{S} 4$ dip and tilt, the S4 speed measurement can then be corrected for tilt using the relationships: 


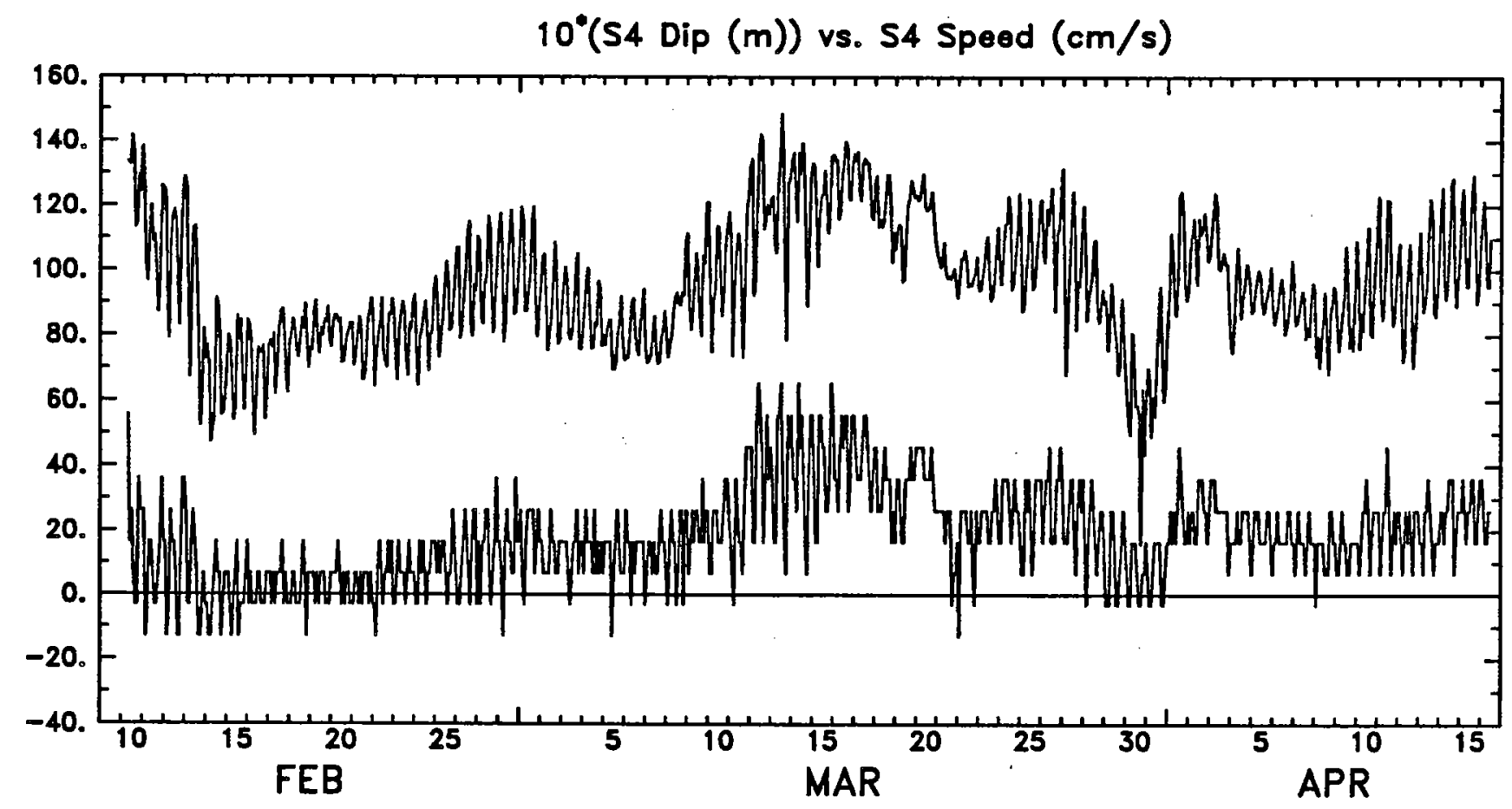

Figure A1: Time series of S4 speed $(\mathrm{cm} / \mathrm{s})$ (upper trace) and S4 dip (decimeters) (lower trace) for entire deployment period. 
$10^{*}(54 \operatorname{Dip}(\mathrm{m}))$ vs. 54 Speed $(\mathrm{cm} / \mathrm{s})$

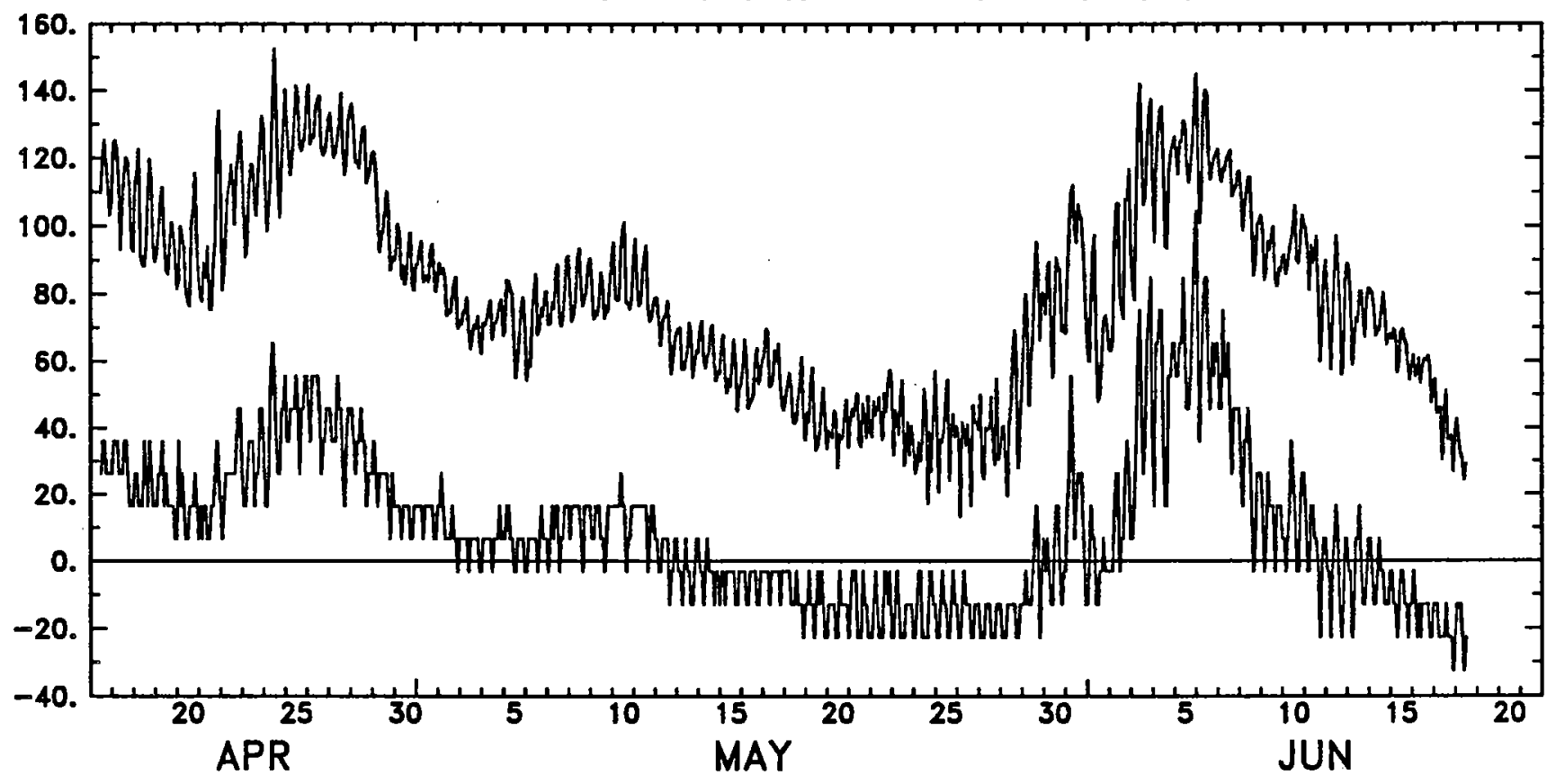

Figure A1: (cont.) 


\section{Table A1}

Unidirectional Velocity Profiles Used as Input Into Mooring Dynamics Model. These profiles were chosen to bracket speeds measured with S4 $(32 \mathrm{~m})$ and bottom SD2000 (93 m) in $103 \mathrm{~m}$ water depth. For simplicity, model water depth is $100 \mathrm{~m}$.

\begin{tabular}{rrrrl}
\hline \multirow{2}{*}{$\begin{array}{c}\text { Profile } \\
\text { Number }\end{array}$} & \multicolumn{3}{c}{ Speed at Depth } & \multicolumn{1}{c}{$\begin{array}{c}\text { Type of } \\
\text { Profile }\end{array}$} \\
\hline & & $30 \mathrm{~m}$ & $100 \mathrm{~m}$ & \multicolumn{1}{c}{} \\
1 & 0 & 0 & 0 & No Current \\
2 & 86 & 60 & 0 & Linear \\
3 & 143 & 100 & 0 & Linear \\
4 & 200 & 140 & 0 & Linear \\
5 & 60 & 60 & 0 & Constant/Linear \\
6 & 100 & 100 & 0 & Constant/Linear \\
7 & 140 & 140 & 0 & Constant/Linear \\
8 & 60 & 60 & 60 & Constant/Linear \\
9 & 100 & 100 & 60 & Constant/Linear \\
10 & 140 & 140 & 60 & Constant/Linear \\
11 & 117 & 100 & 60 & Linear \\
12 & 174 & 140 & 60 & Linear \\
\hline
\end{tabular}

Table A2

Variable Parameters for the Mooring Dynamics Model

\begin{tabular}{ccc} 
Model & $C_{D}$ & Fairing \\
\hline A & 2.6 & None \\
B & 1.3 & None \\
C & 1.3 & $50 \%$ \\
D & 1.3 & $100 \%$ \\
\hline
\end{tabular}




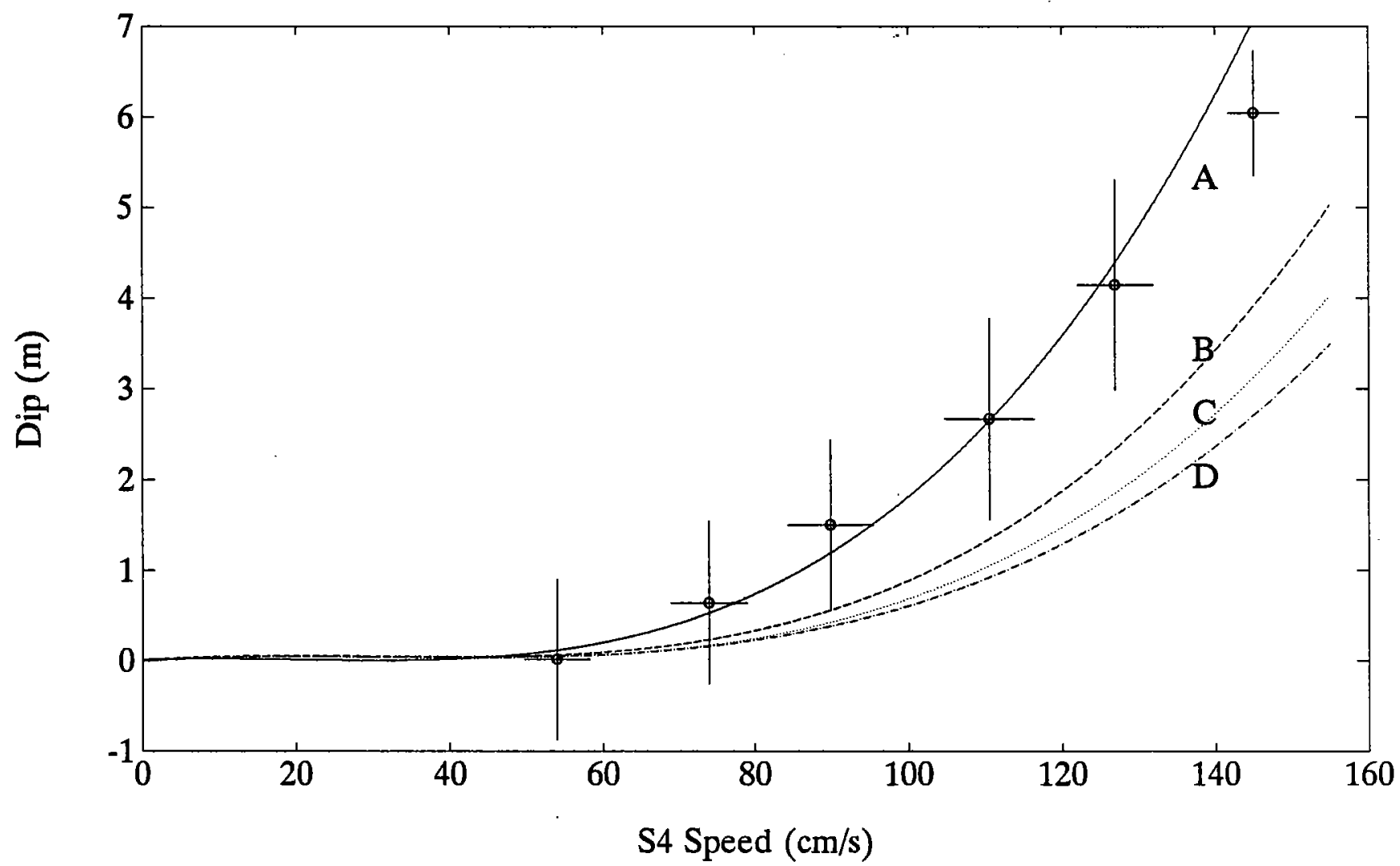

Figure A2: Observed and predicted S4 dip plotted as a function of S4 speed. The observed data were sorted into speed bins and the means and standard deviations of the dip and speed in each bin computed and plotted. For each model, the results for the set of velocity profiles (listed in Table A1) have been least-squares fitted with a simple polynomial which is plotted here with the label A through D. 


$$
\begin{aligned}
\cos (\mathrm{tilt}) & = \begin{cases}1 & \text { if } \operatorname{dip}<0, \\
1-\operatorname{dip}(\mathrm{m}) / 168 \mathrm{~m} & \text { if } \operatorname{dip}>0\end{cases} \\
\mathrm{s}_{c} & =\mathrm{s} / \cos (\mathrm{tilt}),
\end{aligned}
$$

where $s_{c}$ is the corrected speed and $s$ the observed speed. During the first 80 days of the S4 time series, the mean and maximum dip and tilt were 2 and $6 \mathrm{~m}$ and 8 and $16^{\circ}$, respectively. The mean and maximum correction in speed were $1.3 \%$ and $4 \%$.

A comparison of the corrected S4 and top SD2000 current time series (Figure A3) shows a significant difference in speed, with the corrected $\mathrm{S} 4$ speed $\left(s_{S 4}\right)$ reading greater than the SD2000 speed $\left(s_{S D 2000}\right)$ for the first 80 days and then reading less for the final 36 days. Linear regression analysis during these two time periods gives

$$
s_{S D 2000}=-11.1+0.895 * s_{S 4}
$$

(first 80 days, correlation coef. $=.921)$,

$$
s_{S D 2000}=2.6+1.264 * s_{S 4}
$$

(last 36 days, correlation coef. $=.885$ ).

To understand individual instrument performance better, the S4 and top SD2000 current time series were demodulated with a M2 signal using one day non-overlapping windows. The semidiurnal tidal currents are aligned primarily in the cross-shelf direction, so demodulation of the cross-shelf current component with M2 determines the daily amplitude and phase of the semidiurnal constituents. The results show the expected spring/neap cycle, but with the maximum amplitudes of the $S 4$ decreasing from about $48-55 \mathrm{~cm} / \mathrm{s}$ during the first 80 days to roughly $35-40 \mathrm{~cm} / \mathrm{s}$ during the rest of the record. The SD2000 also exhibited a clear spring/neap cycle during the first 80 days with maximum amplitudes of $28-46 \mathrm{~cm} / \mathrm{s}$, but the later behavior was much more erratic with larger maximum amplitudes ranging up to $58 \mathrm{~cm} / \mathrm{s}$. The $\mathrm{S} 4$ maximum daily total current variance (roughly twice the semidiurnal kinetic energy) dropped from about $1600-2000(\mathrm{~cm} / \mathrm{s})^{2}$ during the first 80 days to roughly $600-1000(\mathrm{~cm} / \mathrm{s})^{2}$ during the rest of the record. Since tidal theory does not predict such a large and rapid decrease in semidiurnal energy, we conclude that the significant (order 30-40\%) decrease in S4 current speed after the first 80 days is instrumental. In a similar sense, we also conclude that the increase in SD2000 current speed after the first 80 days is instrumental. There is no clear way to correct either time series so the data presented here contain these instrumental errors. 


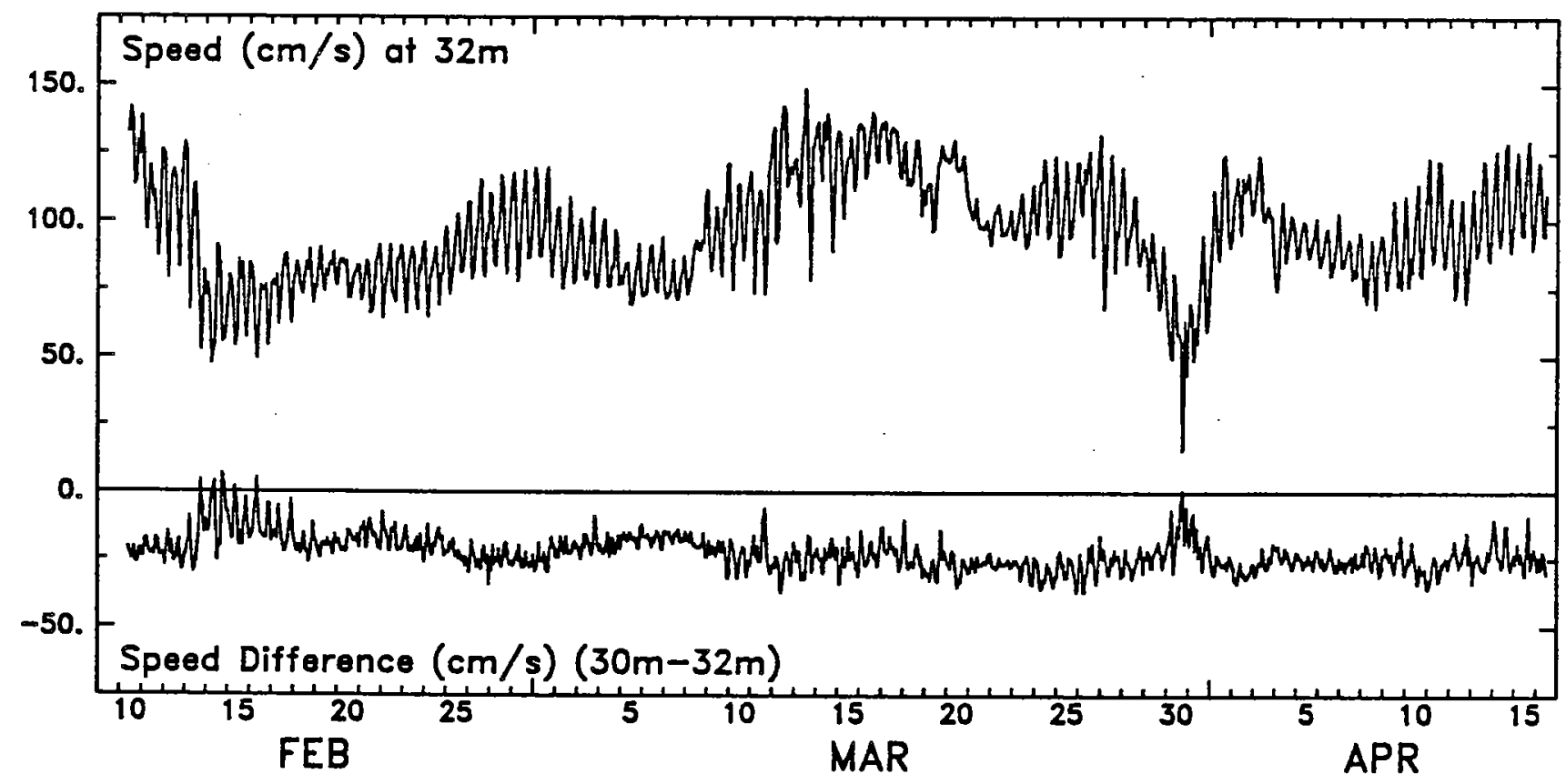

Figure A3: Time series of S4 corrected speed (upper line) and the difference between the top SD2000 speed and the S4 corrected speed for the entire deployment period (lower line). 


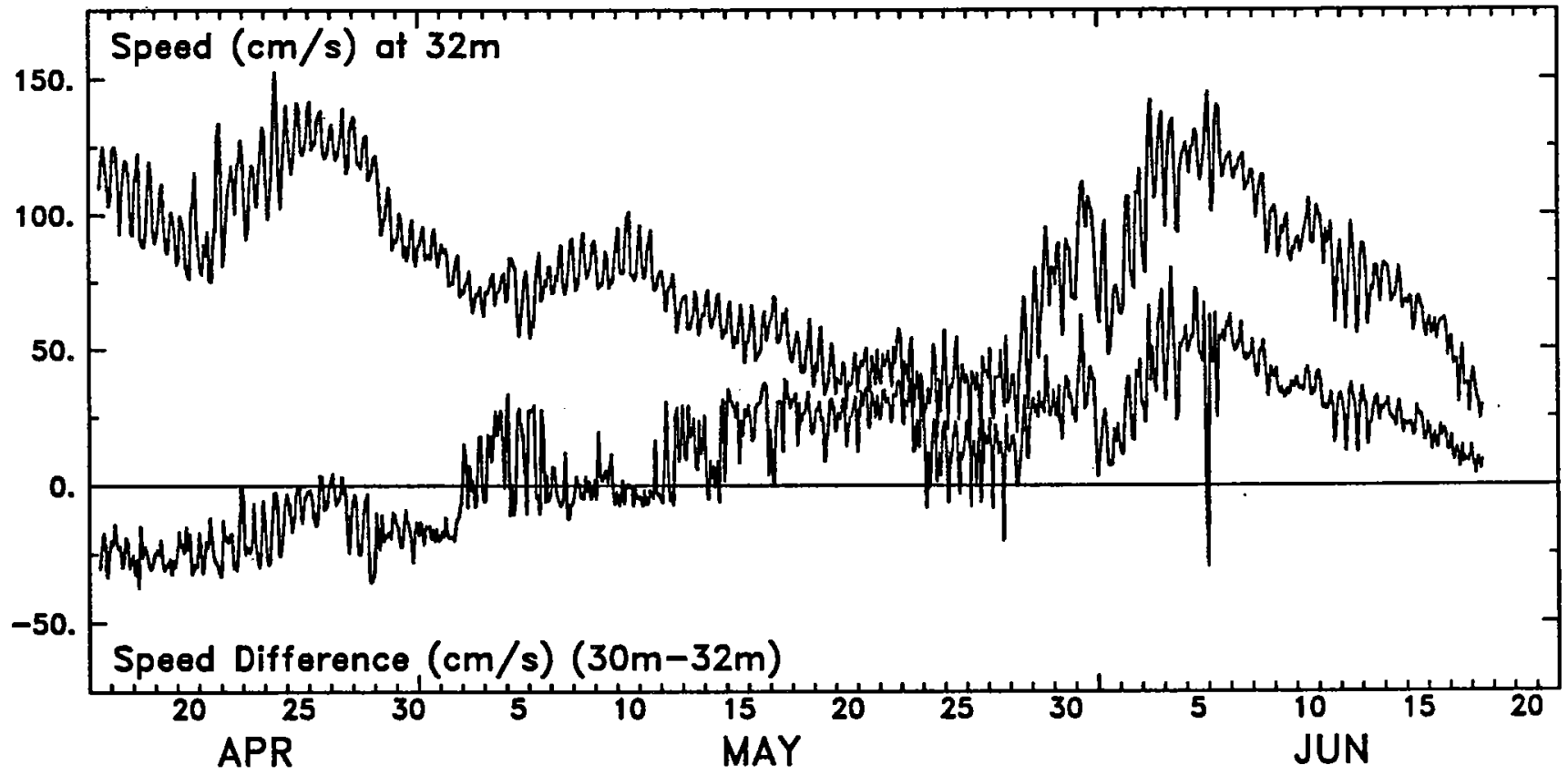

Figure A3 (cont.) 



\section{DOCUMENT LIBRARY}

March 11, 1991

\section{Distribution List for Technical Report Exchange}

Attn: Stella Sanchez-Wade

Documents Section

Scripps Institution of Oceanography

Library, Mail Code C-075C

La Jolla, CA 92093

Hancock Library of Biology \& Oceanography

Alan Hancock Laboratory

University of Southern California

University Park

Los Angeles, CA 90089-0371

Gifts \& Exchanges

Library

Bedford Institute of Oceanography

P.O. Box 1006

Dartmouth, NS, B2Y 4A2, CANADA

Office of the International

Ice Patrol

c/o Coast Guard R \& D Center

Avery Point

Groton, CT 06340

NOAA/EDIS Miami Library Center

4301 Rickenbacker Causeway

Miami, FL 33149

Library

Skidaway Institute of Oceanography

P.O. Box 13687

Savannah, GA 31416

Institute of Geophysics

University of Hawaii

Library Room 252

2525 Correa Road

Honolulu, HI 96822

Marine Resources Information Center

Building E38-320

MIT

Cambridge, MA 02139

Library

Lamont-Doherty Geological

Observatory

Columbia University

Palisades, NY 10964

Library

Serials Department

Oregon State University

Corvallis, OR 97331
Pell Marine Science Library

University of Rhode Island

Narragansett Bay Campus

Narragansett, RI 02882

Working Collection

Texas A\&M University

Dept. of Oceanography

College Station, TX 77843

Library

Virginia Institute of Marine Science

Gloucester Point, VA 23062

Fisheries-Oceanography Library

151 Oceanography Teaching Bldg.

University of Washington

Seattle, WA 98195

Library

R.S.M.A.S.

University of Miami

4600 Rickenbacker Causeway

Miami, FL 33149

Maury Oceanographic Library

Naval Oceanographic Office

Stennis Space Center

NSTL, MS 39522-5001

Marine Sciences Collection

Mayaguez Campus Library

University of Puerto Rico

Mayaguez, Puerto Rico 00708

Library

Institute of Oceanographic Sciences

Deacon Laboratory

Wormley, Godalming

Surrey GU8 5UB

UNITED KINGDOM

The Librarian

CSIRO Marine Laboratories

G.P.O. Box 1538

Hobart, Tasmania

AUSTRALIA 7001

Library

Proudman Oceanographic Laboratory

Bidston Observatory

Birkenhead

Merseyside L43 7 RA

UNITED KINGDOM 


\begin{tabular}{|c|c|c|}
\hline $\begin{array}{l}\text { REPORT DOCUMENTATION } \\
\text { PAGE }\end{array}$ & $\begin{array}{l}\text { 1. REPORT NO. } \\
\text { WHOI-92-36 }\end{array}$ & 3. Recipient's Accession No. \\
\hline \multirow{2}{*}{\multicolumn{2}{|c|}{$\begin{array}{l}\text { 4. Title and Subtitle } \\
\text { A Multidisciplinary Amazon Shelf SEDiment Study (AmasSeds): Physical Oceanography } \\
\text { Moored Array Component }\end{array}$}} & $\begin{array}{l}\text { 5. Report Date } \\
\text { September } 1992\end{array}$ \\
\hline & & 6. \\
\hline \multicolumn{2}{|c|}{$\begin{array}{l}\text { 7. Author(s) } \\
\text { Carol A. Alessi, Steven J. Lentz, Robert C. Beardsley, Belmiro M. Castro and W. Rockwell Geyer }\end{array}$} & $\begin{array}{l}\text { 8. Performing Organization Rept. No. } \\
\text { WHOI } 92-36\end{array}$ \\
\hline \multirow{2}{*}{\multicolumn{2}{|c|}{$\begin{array}{l}\text { 9. Performing Organization Name and Address } \\
\text { The Woods Hole Oceanographic Institution } \\
\text { Woods Hole, Massachusetts } 02543\end{array}$}} & 10. Project/Task/Work Unit No. \\
\hline & & $\begin{array}{l}\text { 11. Contract(C) or Grant(G) No. } \\
\text { (C) OCE88-12917,OCE91-15712 } \\
\text { (G) }\end{array}$ \\
\hline \multirow{2}{*}{\multicolumn{2}{|c|}{$\begin{array}{l}\text { 12. Sponsoring Organization Name and Address } \\
\text { Funding was provided by the National Science Foundation. }\end{array}$}} & $\begin{array}{l}\text { 13. Type of Report \& Period Covered } \\
\text { Technical Report }\end{array}$ \\
\hline & & 14. \\
\hline
\end{tabular}

\section{Supplementary Notes}

This report should be cited as: Woods Hole Oceanog. Inst. Tech. Rept., WHOI-92-36.

16. Abstract (Limit: 200 words)

A Multidisciplinary Amazon Shelf SEDiment Study (AmasSeds) is a cooperative research program by geological, chemical, physical, and biological oceanographers from Brazil and the United States to study sedimentary processes occurring over the continental shelf near the mouth of the Amazon River. The physical oceanography component of AmasSeds included a moored array deployed on the continental shelf approximately $300 \mathrm{~km}$ northwest of the Amazon River mouth near $3.5^{\circ} \mathrm{N}$. The moored array consisted of a cross-shelf transect of three mooring sites located on the $18-\mathrm{m}, 65-\mathrm{m}$, and $103-\mathrm{m}$ isobaths. The moored array was deployed for approximately 4 months, from early February, 1990 to mid-June, 1990, obtaining time series measurements of current, temperature, conductivity, and wind. This report describes the physical oceanography moored array component and provides a statistical and graphical summary of the moored observations.

17. Document Analysis a. Descriptors

1. moored oceanographic observations

2. Amazon River/ North Brazil Continental Shelf

3. AmasSeds (A Multidisciplinary Arnazon Shelf SEDiment Study)

b. Identifiers/Open-Ended Terms

c. COSATI Fleld/Group

18. Avaliability Statement

Approved for publication; distribution unlimited.

\begin{tabular}{|l|c|}
\hline $\begin{array}{c}\text { 19. Security Class (This Report) } \\
\text { UNCLASSIFIED }\end{array}$ & $\begin{array}{c}\text { 21. No. of Pages } \\
100\end{array}$ \\
\hline 20. Security Class (This Page) & 22. Price \\
\hline
\end{tabular}


